MARCIA RODRIGUES GARCIA TAMOSAUSKAS

\title{
Instituições de ensino superior: como o tema drogas é abordado pelos projetos institucionais
}

Tese apresentada à Faculdade de Medicina da Universidade de São Paulo para obtenção do Título de Doutor em Ciências

Programa de Ciências Médicas

Área de concentração: Educação e Saúde

Orientador: Prof. Dr. Mílton de Arruda Martins

São Paulo

2013 
MARCIA RODRIGUES GARCIA TAMOSAUSKAS

\section{Instituições de ensino superior: como o tema drogas é abordado pelos projetos institucionais}

Tese apresentada à Faculdade de Medicina da Universidade de São Paulo para obtenção do Título de Doutor em Ciências

Programa de Ciências Médicas Área de concentração: Educação e Saúde

Orientador: Prof. Dr. Mílton de Arruda Martins

São Paulo 2013 
Dados Internacionais de Catalogação na Publicação (CIP)

Preparada pela Biblioteca da

Faculdade de Medicina da Universidade de São Paulo

(reprodução autorizada pelo autor

Tamosauskas, Marcia Rodrigues Garcia

Instituições de ensino superior : como o tema drogas é abordado pelos projetos institucionais / Marcia Rodrigues Garcia Tamosauskas. -- São Paulo, 2013.

Tese(doutorado)--Faculdade de Medicina da Universidade de São Paulo.

Programa de Ciências Médicas. Área de concentração: Educação e Saúde.

Orientador: Milton de Arruda Martins.

Descritores: 1.Educação em saúde/métodos 2.Educação superior 3.Consumo de bebidas alcoólicas/prevenção \& controle 4 . Consumo de produtos derivados do tabaco/prevenção \& controle 5.Drogas ilicitas 6.Desenvolvimento de programas 7.Política organizacional 8.Universidades 9.Estudantes 10.Questionários 11.Brasil

USP/FM/DBD-377/13 
Tbm gafo sozinho não tece uma manhã : efe precisará sempre de outros gafos. De um que apanhe esse grito que efe e o fance a outro; de um outro ga $\int_{0}$ que apanfie o grito de um gafo antes e o fance a outro; e de outros gafos que com muitos outros gafos se cruzem os fios de sol de seus gritos de gafo, para que a manhãa, desche uma teía tênue, se vá tecendo, entre todos os gafos.

E se encorpando em tela, entre todos, se erguendo tenda, onde entrem todos, se entre tendendo para todos, no toldo (a manhã) queplana fivre de armação. 荤anhã, toldo de um tecido tão aéreo que, tecido, se efeva por si: fuz бa $\int_{\tilde{a} \mathrm{o}}$.

Loão Gabras de Meso Neto, 華芒ducação pela Pedra 1966)

Ed đótfaguara/Objetivo 
Dedico esta tese:

aos meus filhos, Tatiana, Thiago e Felipe, razão das minhas lutas e conquistas, e ao meu marido Eddy, companheiro de todas as horas, que me apoiaram cada instante da minha trajetória. 


\section{AGRADECIMENTOS}

Agradeço a todas as pessoas que contribuíram para que este momento se concretizasse.

Em especial, à minha família.

Aos meus pais, Raphael e Olinda que sempre me apoiaram e estiveram ao meu lado e são motivo de inspiração e exemplo de vida.

Aos meus irmãos Carlos, Clovis e Claudio pela confiança que sempre depositaram em mim.

A Registila, amiga que me acolheu nos momentos difíceis do início da pesquisa, pela amizade, carinho, confiança e pelo incentivo.

A Mílton de Arruda Martins pela orientação atenta e precisa.

A Elci e Jossi, pela amizade, observações e por concederem tempo para que eu pudesse conciliar minhas atividades profissionais e acadêmicas

Aos amigos da Faculdade de Medicina do ABC, pela amizade, incentivo e atenção.

Aos colegas do departamento de Patologia pela partilha do caminho percorrido.

A todos os amigos que, de alguma forma, apoiaram este trabalho.

À Rosana pela amizade, atenção cuidadosa e ajuda sempre presente. 

Esta tese está de acordo com as seguintes normas, em vigor no momento desta publicação:

Referências: adaptado de International Committee of Medical Journals Editors (Vancouver).

Universidade de São Paulo. Faculdade de Medicina. Divisão de Biblioteca e Documentação. Guia de apresentação de dissertações, teses e monografias. Elaborado por Anneliese Carneiro da Cunha, Maria Julia de A. L. Freddi, Maria F. Crestana, Marinalva de Souza Aragão, Suely Campos Cardoso, Valéria Vilhena. 3a ed. São Paulo: Divisão de Biblioteca e Documentação; 2011.

Abreviaturas dos títulos dos periódicos de acordo com List of Journals Indexed in Index Medicus. 


\section{SUMÁRIO}

Lista de Abreviaturas

Lista de Tabelas

Lista de Figuras

Resumo

Summary

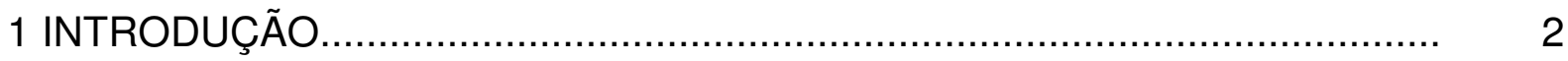

1.1 Uso de drogas no mundo........................................................... 2

1.2 Uso de drogas no Brasil............................................................ 3

1.3 Uso de drogas entre estudantes universitários..................................... 4

1.4 Uso de drogas entre universitários brasileiros........................................... 7

1.5 Programas de prevenção ao consumo de drogas em instituições de ensino superior.

1.6 Programas de prevenção ao consumo de drogas e o ensino superior no Brasil.

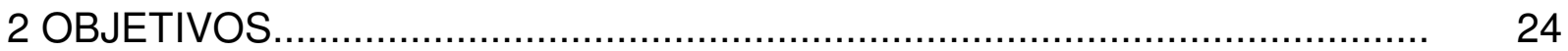

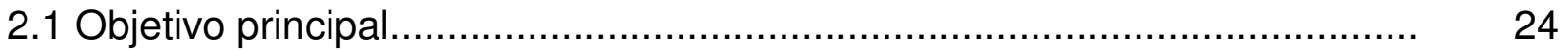

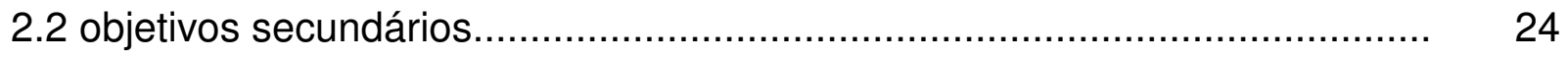

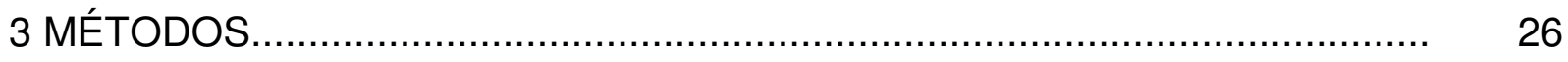

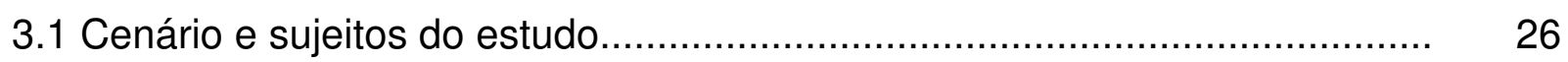

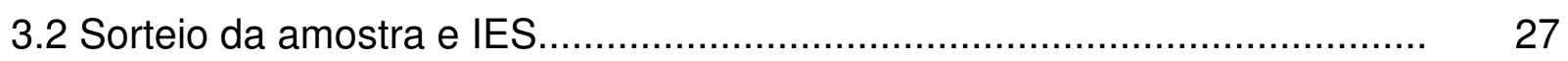

3.3 Sorteio da amostra de turma de alunos............................................. 28

3.4 Instrumentos de coleta de dado............................................................. 28

3.4.1 Questionário a ser respondido pelos alunos 28

3.4.2 Questionário a ser respondido pela instituição 29

3.4.3 Pesquisa nos sites 29

3.5 Análise do perfil dos programas institucionais..................................... 31

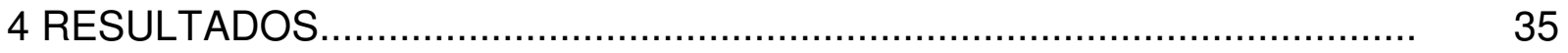


4.1 Descrição da amostra................................................................ 35

4.2 Resposta dos alunos ao questionário................................................... 38

4.3 Resposta das instituições ao questionário.............................................. 46

4.4 Pesquisa no site.............................................................................. 53

4.5 Site e questionário..................................................................... 54

4.6 Análise dos projetos....................................................................... 54

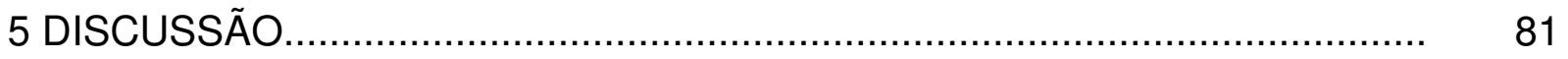

5.1 Discussão dos dados obtidos através dos questionários 83

5.2 Discussão dos dados obtidos na análise dos projetos 93

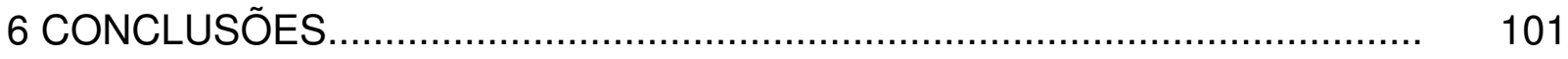

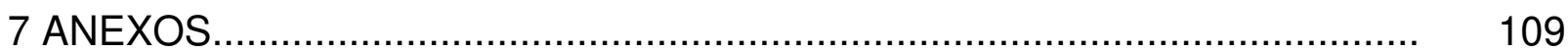

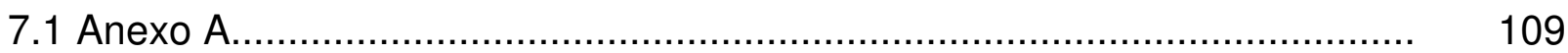

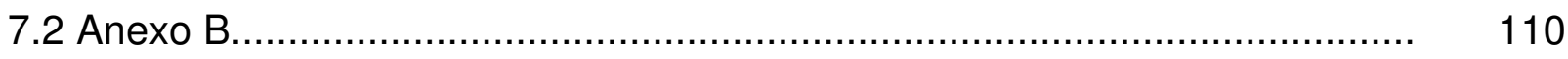

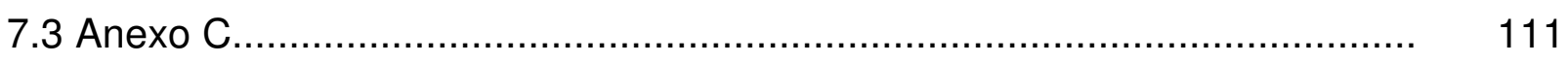

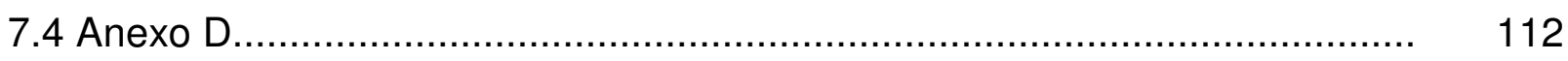

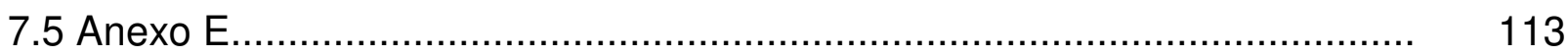

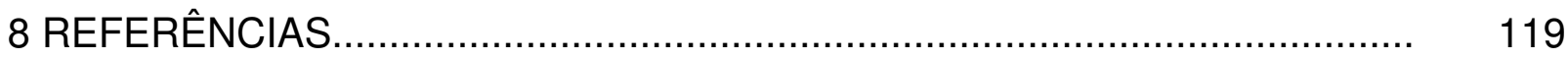




\section{LISTA DE ABREVIATURAS}

CAPPESq - Comissão de Ética para Análise de Projetos em Pesquisa FMUSP - Faculdade de Medicina da Universidade de São Paulo GREA - Grupo Interdisciplinar de Estudos de Álcool e Drogas IES - Instituição de Ensino Superior INEP - Instituto Nacional de Estudos e pesquisas educacionais Anisio Teixeira LDB Lei de Diretrizes e Bases da Educação MEC - Ministério de Educação e Cultura OMS- Organização Mundial da Saúde PDI - Plano de Desenvolvimento Institucional PPI - Projeto Pedagógico Institucional SENAD - Secretaria Nacional de Políticas sobre Drogas UNESCO - United Nations Educational, Scientific and Cultural Organization UNODC - United Nations Office for Drug Control and Crime URL - (Uniform Resource Locator) -Localizador Padrão de Recursos U S - United States 


\section{LISTA DE TABELAS}

Tabela 1 - Distribuição das IES por região e regime administrativo

Tabela 2 - Distribuição das IES participantes por número de cursos oferecidos e regime administrativo

Tabela 3 - Distribuição dos estudantes pesquisados por região administrativa Tabela 4 - Distribuição dos alunos que responderam ao questionário por gênero e regime administrativo da instituição

Tabela 5 - Distribuição das respostas dos alunos em relação a existência de programas de atendimento à saúde do aluno e sua distribuição por gênero em numero, absoluto e porcentagem

Tabela 6 - Distribuição das respostas em porcentagem quanto a existência de um programa de atendimento à saúde do aluno em relação à região administrativa e tipo de IES

Tabela 7 - Distribuição das respostas quanto a existência de um programa de atendimento à saúde do aluno em relação a curso em que estava matriculado Tabela 8 - Distribuição das respostas por gênero e tipo de IES em que o aluno estava, referentes ao uso do programa de atendimento à saúde dos alunos Tabela 9 - Distribuição por região administrativa das respostas em relação ao uso do programa de atendimento à saúde dos alunos Tabela 10 - Distribuição das respostas, conforme o curso em que o aluno está matriculado, em relação ao uso do programa de atendimento à saúde dos alunos 
Tabela 11 - Distribuição das respostas por gênero, região administrativa e tipo de IES quanto a ter recebido informações sobre o uso de drogas e seu impacto na saúde nos últimos 12 meses.

Tabela12 - Frequência das respostas dos estudantes por área do curso quanto a ter recebido informações sobre o uso de drogas e seu impacto na saúde nos últimos 12 meses.

Tabela 13 - Distribuição das respostas dos estudantes quanto metodologia empregada na divulgação de informações sobre o uso de drogas e seu impacto na saúde nos últimos 12 meses analisados área do curso e gênero ( mais de uma resposta possível) $\mathrm{N}=3.150$

Tabela 14 - Distribuição das respostas por tipo de IES e região administrativa quanto a metodologia empregada na divulgação de informações sobre o uso de drogas, seu impacto na saúde nos últimos 12 meses (possibilidade de assinalar mais de uma resposta) $\mathrm{N}=3.150$

Tabela 15 - Distribuição das respostas quanto a possibilidade de encontrar ajuda na IES para reduzir ou parar o consumo de álcool ou outras drogas.

Tabela 16 - Distribuição do número de cursos oferecidos pelas IES que responderam de modo afirmativo quanto à existência de programas de prevenção, orientação ou assistência ao consumo de drogas pelos estudantes ao questionário.

Tabela 17 - A distribuição dos programas existentes por região administrativa e tipo de IES de acordo com as respostas ao questionário Tabela 18 - Frequência das estratégias de divulgação interna dos programas de prevenção orientação ou assistência presentes nas IES 
Tabela 19 - Distribuição dos responsáveis pelo projeto nas instituições.

Tabela 20 - Distribuição dos projetos analisados e total de projetos por região administrativa. 


\section{LISTA DE FIGURAS}

Figura 1 - Ações planejadas como enfrentamento ao consumo de drogas segundo o objetivo das IES

Figura 2 - Ações planejadas como enfrentamento ao consumo de drogas segundo o objetivo das IES 
Tamosauskas MRG. Instituições de Ensino Superior: como o tema drogas é abordado pelos projetos institucionais [tese]. São Paulo: Faculdade de Medicina, Universidade de São Paulo; 2013.

O presente estudo se propõe a Identificar o número de Instituições de Ensino Superior (IES) que desenvolvem programas relacionados ao tema drogas nas áreas de ensino, prevenção e assistência e descrever o perfil de seus programas, além de conhecer como os alunos percebem a existência de ações de apoio à saúde, informações e ajuda sobre o consumo de drogas. Participaram do estudo 100 Instituições de Ensino Superior, localizadas nas 27 capitais dos estados brasileiros. Os alunos foram selecionados por sorteio sistemático das classes em cada instituição. Como instrumentos de coleta de dados foram utilizados: pesquisa aos sites institucionais, questionário estruturado respondido pelos alunos, questionário semiestruturado respondido pela instituição e analise qualitativa pela técnica de análise de conteúdo dos programas. Apesar da maioria dos estudantes saber da existência de serviços atendimento de saúde direcionados aos alunos, poucos utilizam o serviço, enquanto $71 \%$ dos alunos referem não ter recebido informações referentes ao uso de drogas e seu impacto na saúde em sua escola, no último ano. Das 100 IES, 82 instituições responderam ao questionário e destas, $32,9 \%$ (27 instituições) informam a existência de programas de prevenção, assistência ou orientação ao uso de álcool, tabaco ou outras drogas. Dos 27 programas, $51,9 \%$ fazem parte do projeto pedagógico institucional. As ações incluem prevenção $81,5 \%$ (22 em 27) associada a atividades de orientação $(44,4 \%)$ e/ou assistência $(48,1 \%)$. Os núcleos de apoio psicopedagógico existem em mais de metade nas instituições que têm programas relacionados ao uso de drogas. Foram analisados 18 programas, todos atuam na área da prevenção, mas são muito diversificados em abrangência, população alvo e atividades planejadas. Conclusões: No Brasil não é uma exigência legal a existência de projetos que tenham esse foco. A porcentagem de escolas com programas é pequena e deve ser estimulada a criação de programação de orientação para álcool, tabaco e outras drogas. Uma avaliação sistematizada interna e externa dos programas é necessária para identificar resultados efetivos, e para isso devem atuar em múltiplas frentes com uma participação ampliada do corpo diretivo, estudantes, docentes, funcionários e membros da comunidade. Além de fornecer informações, os programas devem ter por objetivo contribuir para mudar as atitudes e comportamentos.

Descritores: Educação em saúde/métodos; Educação superior; Consumo de bebidas alcoólicas/prevenção \& controle; Consumo de produtos derivados do tabaco/prevenção \& controle; Drogas ilícitas; Desenvolvimento de programas; Política organizacional; Universidades; Estudantes; Questionários; Brasil. 
Tamosauskas MRG. Higher Education Institutions: How the topic drugs is addressed by the institutional projects [thesis]. São Paulo: "Faculdade de Medicina, Universidade de São Paulo"; 2013.

This study's proposal is to identify the number of Higher Education Institutions (IES - Instituições de Ensino Superior) that develop programs related to the topic drugs in the areas of teaching, prevention and assistance, describe the profile of said programs, as well as learn how the students perceive the existence of initiatives on improving health, and providing information and support related to the consumption of drugs. 100 Higher Education Institutions participated on the study, 27 located in the capitals of the Brazilian states. The participating students classes were randomly chosen through computer-aided randomization in each institution. The utilized instruments for the collecting data were: searches on the institution websites, semi structured survey answered by the students, semi structured survey answered by the institution, and the qualitative analysis through the technique of program content analysis. Although most students knew about the existence of healthcare services directed to students, few utilized the service, while $71 \%$ of the students report for the last year not having received in their schools, information related to the usage of drugs and it's impact on health. Of the 100 IES, 82 institutions answered the survey and of those, 32,9\% (27 institutions) informed the existence of programs for prevention, assistance or guidance regarding the usage of alcohol, tobacco or other drugs. Of the 27 programs, $51,9 \%$ are part of the institutional pedagogical Project. The initiatives include prevention $81,5 \%$ (22 out of $27)$, related to guidance activities $(44,4 \%$ and/or assistance $(48,1 \%)$. The psycho pedagogic support groups exist in more than half institutions that have programs related to the usage of drugs. 18 programs were analyzed, all acting in prevention, but very distinct in range, target population and planned activities. Conclusions: Brazil does not have a legal requirement of the existence of projects with this focus. The percentage of schools with programs is small and the creation of programs of guidance on alcohol, tobacco and other drugs must be stimulated. A systematic evaluation of the internal and external programs is needed to identify effective results, and for that this evaluation must act on multiple fronts with an extended participation of the directive body, students, teachers, employees and community members. Besides supplying information, the programs must have an objective of contributing to the changing of attitudes and behaviors.

Descriptors: Health education/methods; Education, higher; Alcohol drinking/prevention \& control; Consumption of tobacco-derived; Street drugs; Program development; Organizational policy; Universities; Students; Questionnaires; Brazil. 
A MUDANÇA IMPLICA NA DIALETIZAÇÃO ENTRE DENUNCIA DA SITUAÇÃO DESUMANIZANTE E O ANUNCIO DE SUA SUPERAÇÃO, NO FUNDO,

O NOSSO SONHO. PAUlo Freire, PEDAGOGIA DA AutONOMIA, 1996 
O uso de drogas acompanha a humanidade desde a pré-história, com diferentes objetivos. Elas já foram utilizadas pelos homens para alimentação, remédio para seu corpo e sua alma, para proporcionar-lhes conforto, alterar seus estados de consciência, alcançar a paz ou a excitação, isolar-se do mundo ou mediar o contato com o transcendente e se aproximar do sobrenatural/divino (Koutouzis, 1996), variando com cada época e cada cultura, muitas vezes difundidas em práticas sociais e rituais religiosos.

O aspecto etimológico da palavra "droga" não está bem estabelecido: alguns atribuem sua origem a partir do neerlandês droogen, que significa seco, mercadoria enxuta; outros ao persa daru (medicina), termo que migra para o francês drogue e para o italiano droga, identificando substâncias usadas na farmacologia. Esse mesmo termo designa igualmente coisas sem utilidade e também é sinônimo de tóxico (Silva, 2004 p.277).

A Organização Mundial da Saúde (OMS, 1978) define droga como qualquer substância não produzida no organismo, capaz de modificar o funcionamento dos organismos vivos e levar a mudanças fisiológicas ou de comportamento, podendo ser medicinal ou nociva (Galduróz, Noto \& Carlini, 1997).

Nas últimas décadas, a abordagem do tema drogas, desde a prevenção de uso até o tratamento e reabilitação (em situações de dependência), tem sido tema de debate tanto no meio científico quanto na comunidade em geral.

\subsection{Uso de drogas no mundo}

Dados de 2007 mostram que 172 milhões de pessoas no mundo utilizaram algum tipo de substância psicoativa, e a maconha foi a droga mais prevalente (UNODC, 2009). Dados mais recentes mostram que o consumo não apresentou grandes mudanças entre 2006 e 2011 (UNODC, 2012). Nesses cinco anos o consumo de drogas ilícitas se manteve estável entre 3,4\% e 6,6\% da população adulta de 15 a 64 anos, significando que entre 153 e 300 milhões de pessoas consumiram uma droga ilícita pelo menos uma vez no último ano (uma em cada 20 pessoas); e que de $10 \%$ a $13 \%$ dos usuários de drogas são consumidores problemáticos, ou seja, aqueles que sofrem maiores danos e tornam-se 
dependentes, o que corresponde ao número de 15,5 a 38 milhões de pessoas. As mortes decorrentes desse consumo correspondem entre 0,5\% a $1,3 \%$ da mortalidade geral em todo o mundo (UNODC, 2012). Aproximadamente 170 milhões de pessoas, o que corresponde a $3,8 \%$ da população mundial, consomem maconha pelo menos uma vez ao ano. As pesquisas mostram ainda que o tabaco, no mês anterior à coleta dos dados, foi consumido por $25 \%$ da população maior de 15 anos, ou seja, dez vezes a prevalência do total de consumo de drogas ilícitas no mesmo período, enquanto a prevalência do uso do álcool no último ano foi de 42\% (UNODC, 2012).

O consumo de drogas ilícitas se concentra na população jovem: o início começa a ocorrer na adolescência ou na fase adulta jovem. O uso legal de tabaco e álcool continua em proporções maiores à medida que a idade aumenta, de modo que o consumo de substâncias psicoativas legais tende a uma distribuição mais homogênea que o de drogas ilícitas entre as diferentes faixas etárias (UNODOC, 2012). Apesar de apresentar sinais de estabilização em países desenvolvidos, seu aumento se mostra constante em países em desenvolvimento.

\subsection{Uso de drogas no Brasil}

No Brasil, 22,8\% da população entre 12 e 65 anos, que significa 11.603.000 de pessoas, fez uso de drogas psicoativas na vida, segundo dados do "Il Levantamento Domiciliar sobre o uso de drogas psicotrópicas no Brasil: envolvendo 108 maiores cidades do país" (Carlini et al., 2007). Esses números não incluem o uso de tabaco, com prevalência de 44\%, e do álcool, com prevalência de 74,6\%, drogas lícitas no nosso país (Carlini et al., 2007).

Segundo dados do "V Levantamento Nacional sobre o consumo de Drogas Psicotrópicas entre estudantes do ensino Fundamental e Médio nas 27 Capitais Brasileiras", 22,6\% dos pesquisados fizeram uso na vida de substância psicoativa (exceto tabaco ou álcool), da seguinte forma: entre 10 e 12 anos, 12,7\%; entre 13 e 15 anos, 23,1\%; entre 16 e 18 anos, 29,2\% e maiores de 18 anos, 34,7\%; 3,0\% 
dos entrevistados fazem uso frequente de drogas psicotrópicas (Galduróz et al., 2005).

De acordo com o Relatório Brasileiro sobre drogas da Secretaria Nacional de Políticas sobre Drogas do Ministério da Justiça (Brasil, SENAD, 2009), a porcentagem de estudantes do ensino fundamental e médio no Brasil que já fizeram uso na vida de drogas psicoativas é maior que a de diferentes países da América do Sul e da América Central, como Chile (19,8\%), Uruguai (13,5\%) e Paraguai $(5,6 \%)$ (Duarte et al., 2009).

\subsection{Uso de drogas entre estudantes universitários}

O período de entrada na universidade pode ser considerado uma fase de vulnerabilidade: o consumo de drogas aumenta por diversos fatores: desejo de inserção social, fazer parte da comunidade de iguais ou como um rito de iniciação simbólico (Abramovay e Castro, 2005). Some-se a isso o distanciamento da família, morar com outros estudantes e ausência da supervisão direta de adultos (Peuker, 2006).

Um levantamento realizado em 119 universidades norte-americanas de 1993 a 2001 evidenciou uma tendência de aumento de problemas relacionados ao uso de álcool no período. Nesse estudo, o ambiente universitário foi descrito não só como pouco restritivo em relação ao consumo de álcool como também foi frequentemente considerado como um local propício para o uso de substâncias psicoativas, iniciando-se ali um período de experiências e exploração (Wechsler et al., 2002).

O projeto Monitoring the Future acompanha há 37 anos a prevalência do uso de drogas entre estudantes da oitava série até a idade adulta, incluindo uma categoria de estudantes universitários. O estudo é patrocinado pelo National Institute on Drug Abuse, do National Institute of Health, e executado pela University of Michigan. Tem como objetivo servir de marcador social, caracterizar níveis e tendências de comportamento, entre outros (Johnston, 2012). O estudo de 
2011 mostra que o uso na vida de drogas ilícitas entre universitários teve uma prevalência de 49,2\%: o de álcool foi de $81 \%$ no mês, enquanto as taxas de uso no ano foram de 36,3\% para drogas ilícitas, 77,4\% para álcool e 25,8\% para tabaco. Os universitários se destacam por apresentar uma taxa de beber pesado ocasional (binge) de $40 \%$, enquanto entre os não universitários essa taxa foi de $34 \%$. O consumo diário de cigarros mostra uma diferença importante entre os universitários $(7 \%)$ e não universitários da mesma faixa etária (21\%).

Em 2012, as taxas de prevalência do uso na vida por estudantes universitários americanos foram de 50,5\% para alguma droga ilícita e de $81 \%$ de álcool; e, no ano, de 37,3\% de drogas ilícitas e 79,2\% de álcool (Johnston, 2013). Essas taxas são maiores do que as encontradas entre estudantes do ensino médio e jovens não universitários.

Bahman $(1997,2002)$ entende que o fato de deixar a casa dos pais após o ensino médio e o fato de o casamento ocorrer mais tardiamente podem se configurar como fatores importantes. Participar de uma fraternidade está associado ao aumento da frequência do beber pesado episódico, segundo MacCabe (2005). A taxa anual de tabagismo entre universitários foi de 13\%, mostrando uma tendência à diminuição. Lord (2009) estudou em Nova York o consumo de analgésicos opiáceos em estudantes de farmácia da Private College of Pharmacy, verificando que $8 \%$ fizeram uso durante a vida e $5 \%$ uso no ano.

Diferentes países apresentam estudos que visam conhecer 0 comportamento dos seus jovens universitários. Na Inglaterra, Underwood et al. (2010) estudaram a prevalência de álcool, tabaco e outras drogas entre estudantes de odontologia. Eles relatam que houve diminuição do consumo de cocaína e anfetaminas pelos homens; aumento do consumo de álcool e diminuição do tabaco pelas mulheres. Webb et al. (1996) realizaram um estudo em diferentes universidades da Europa (Inglaterra, Escócia e País de Gales), mostrando que $63 \%$ dos estudantes pesquisados relataram o consumo de drogas ilícitas e $28 \%$ assumiram o beber pesado episódico (binge).

Na Turquia, a prevalência do uso de drogas ilícitas na vida é de $4 \%$ entre os estudantes de medicina pesquisados, enquanto a do uso de álcool é de $7,4 \%$ e a 
de tabaco 39,9\% (Akvadar et al. 2003). No Líbano, na Índia e no Irã, diferentes estudos mostram consumo preocupante de drogas psicoativas (Karam et al., 2004; Amiri et al., 2009; Saddichha et al., 2010).

Na Lituânia, Gostautas (2009) estudou o consumo de drogas e álcool entre universitários, observando, em relação às drogas, o uso, entre os homens, de $35,9 \%$, e entre as mulheres de 17,7\%, e, em relação ao álcool, o uso várias vezes por mês, sendo de $39,5 \%$ entre os homens e $55,9 \%$ entre as mulheres. $\mathrm{Na}$ Alemanha, Akmatov et al. (2011), em estudo realizado em 17 universidades, relatam um consumo de álcool por mais de $90 \%$ dos alunos nos últimos três meses e que o beber pesado entre os alunos entrevistados era comum, sugerindo a necessidade de um programa de intervenção.

Um estudo de Assanangkornchai (2009), em pesquisa com estudantes do ensino médio e universitários de 40 províncias da Tailândia, constatou que a prevalência da ingestão de álcool no último ano entre universitários do sexo masculino foi de $25,5 \%$, e entre as mulheres de $14,5 \%$ nesse mesmo período; considerando os últimos trinta dias, as frequências são de 9,5\% entre os homens e de $3,7 \%$ entre as mulheres; $17,3 \%$ dos homens e $7,3 \%$ das mulheres referiam episódios de beber pesado ocasional (binge). A pesquisa mostra ainda que bebedores ocasionais pesados (binge) eram mais propensos às consequências do consumo, como dirigir depois de beber, portar arma, tentativa de suicídio. Conclui que o consumo de álcool é um problema grave entre os jovens na Tailândia e que medidas de intervenções específicas para o gênero e idade devem ser implementadas.

Johnston (2013) observa que o problema do uso de drogas não é um inimigo que pode ser vencido, mas uma recorrência do problema que deve ser contido com um processo dinâmico, contínuo, lembrando o perigo da substituição permanente por novas substâncias que poderão atrair os jovens. 


\subsection{Uso de drogas entre estudantes universitários brasileiros}

No Brasil diversos autores têm pesquisado o consumo de drogas, tabaco e álcool nas universidades. Alguns trabalhos têm como tema o uso de drogas lícitas, como o de Rondina (2001), que estudou o uso de tabaco em diversos cursos de duas universidades particulares em Mato Grosso. Estudos sobre o consumo do álcool foram realizados por Peuker (2006) na Universidade Federal do Rio Grande do Sul; por Rodrigues (2007) na Universidade Católica Dom Bosco, no Mato Grosso do Sul, e por Paduani (2008), que estudou o uso de tabaco e álcool na Universidade Federal de Uberlândia.

Em 1986, Brenes realiza um estudo sobre uso de drogas ilícitas entre universitários de Universidade de Pelotas, enquanto outros autores estudam a frequência de drogas licitas e ilícitas em diversos estados: Fiorini (2003) faz seus estudos com estudantes de Minas Gerais em duas universidades da cidade de Alfenas, uma pública e uma particular; Canuto (2006) estuda o uso de drogas ilícitas por alunos do primeiro ano na Universidade Federal de Goiás; Wagner (2008 e 2011), na Universidade de São Paulo; Botti (2010), na Universidade Católica de Minas Gerais, e Alves (2013) na Universidade Braz Cubas, em São Paulo.

Alguns trabalhos avaliam estudantes de áreas específicas, como Oliveira (2007) e Portugal (2008), que analisam o uso por estudantes do curso de Farmácia; Portugal (2011), que faz o estudo com os estudantes de Pedagogia na Universidade Federal do Espirito Santo; Lucas (2006), na Universidade Federal do Amazonas, na área de Ciências da Saúde, e Chiapetti (2007), na Universidade de Curitiba. Em cursos específicos dessa área, houve os estudos de Barria (2000) no curso de Biologia na Universidade de São Paulo; de Mardegan (2008), no curso de Enfermagem da Universidade Federal do Espirito Santo; de Picolotto (2010), na Universidade de Passo Fundo, e de Silva (2012) na Universidade Federal de Sergipe, com estudantes de Educação Física. Ainda na área da Saúde, os estudantes de Medicina foram foco de diferentes trabalhos: Kerr-Corrêa (1999), na Universidade Estadual de São Paulo; Bastos (1999), na Universidade Federal de 
Sergipe; Costa (2004) e Lemos (2007), nas escolas de Medicina de Salvador, e Pereira (2008) na Universidade Federal do Espirito Santo. É nessa área que aparece o maior número de trabalhos. Mattos e Souza (1999), na Universidade Federal do Ceará, relacionam uso de substâncias psicoativas e desempenho acadêmico: os estudantes relatam influência do consumo de álcool em suas atividades como falta de atenção (10\%), ausência $(6,2 \%)$, dormir durante a aula $(5,4 \%)$ e atraso $(3,3 \%)$.

Devem ser destacados os trabalhos de Andrade (1997), Stempliuk (2005) e Silva (2006) na Universidade de São Paulo; de Rodrigues (2007), na Universidade Católica Dom Bosco, em Mato Grosso do Sul e de Horta (2012), na Universidade do Vale do Rio dos Sinos, mais abrangentes, analisando estilo de vida e comportamento dos estudantes, além da prevalência do uso de drogas licitas e ilícitas.

Todos esses trabalhos estudam uma amostra reduzida de instituições, sendo que a maioria dos estudos abrange estudantes de uma instituição ou apenas uma área ou um curso, e mostram a mesma tendência em instituições públicas e privadas em diferentes locais do país, mas faltava ainda um projeto amplo que pudesse mostrar a distribuição desses dados em todo o Brasil. Com a finalidade de se obter uma visão mais próxima do real do consumo de substâncias psicoativas pelos universitários brasileiros, foi realizado o "I Levantamento nacional sobre o uso de álcool, tabaco e outras drogas entre universitários brasileiros" pela Secretaria Nacional de Políticas sobre Drogas (SENAD), em parceira com a Faculdade de Medicina da Universidade de São Paulo - FMUSP (Andrade et al., 2010), estudando a prevalência do uso de álcool, tabaco e outras drogas, os problemas decorrentes desse consumo e os comportamentos de risco e avaliação da saúde mental do universitário. Além de utilizar uma amostra nacional (27 capitais), o estudo procurou abranger escolas públicas e privadas, as diferentes áreas de curso (humanas, exatas e biológicas), período de estudo, gênero e faixa etária. Este estudo foi dividido em oito subprojetos, entre eles o projeto "Políticas Institucionais: como o tema drogas é abordado pelos projetos institucionais?".

Segundo esse levantamento nacional, a prevalência do uso do álcool na vida, entre universitários brasileiros, é de $86,2 \%$, e a proporção desse uso é 
semelhante para os gêneros masculino e feminino. Um dado importante é que mais de $50 \%$ dos estudantes iniciaram seu consumo antes do 16 anos, fato que expõe mais precocemente essa população aos prejuízos agudos e crônicos decorrentes desse consumo (Andrade, 2010). No último ano, a prevalência do consumo de álcool foi de $72 \%$ e de $60,5 \%$ nos últimos 30 dias, enquanto $22 \%$ dos universitários estão sob o risco de desenvolver dependência ao álcool. Esses dados são superiores aos observados na população brasileira em geral: $74,6 \%$ na vida, $49,8 \%$ nos últimos doze meses e $30,3 \%$ no último mês. Entre estudantes do ensino médio, aqui o consumo é menor, sendo 65,2\% o uso na vida, enquanto essa população na Europa apresenta uma prevalência de $89 \%$ nesse mesmo período. Os universitários dos Estados Unidos têm uma prevalência de 85,3\% ao ano, segundo Oliveira et al. (2010).

Quanto ao tabaco, 46,7\% dos estudantes universitários fizeram uso na vida, 27,8\% nos últimos 12 meses e 21,6\% no último mês, índices maiores que na população brasileira em geral, respectivamente 44\%, 19,2\% e 18,4\% (Oliveira et al., 2010).

Em relação ao uso de drogas ilícitas, 48,7\% na vida (maior que na população em geral, 44\%); 35,8\% no ano (população em geral, 10,3\%) e 25,9\% no mês (população em geral 4,5\%). A prevalência é maior entre os universitários, sendo a maconha a droga ilícita mais consumida. (Nicastri et al., 2010). Os estudantes do ensino fundamental e do médio têm uma prevalência menor na vida $(22,6 \%)$, no ano $(19,6 \%)$ e no último mês (14,8\%). Comparando os índices, os universitários têm um consumo maior na vida, no ano e no mês que a população brasileira. O geral é também maior quando consideramos os estudantes do ensino fundamental e do médio. Quando comparados aos universitários dos Estados Unidos, observa-se que os números são semelhantes nos três indicadores (Oliveira et al., 2010).

O consumo de drogas tem importantes repercussões para o indivíduo. A primeira consequência é no âmbito da saúde, desenvolvendo quer dependência, quer enfermidades; depois, a econômica, com perda da produtividade no trabalho 
por incapacidades ou ausências; e, ainda, consequências para a sociedade, em sua vinculação com a violência e a delinquência (UNODOC, 2012).

Apesar das evidências do consumo de drogas entre os universitários, é difícil o reconhecimento do problema em estágios iniciais, o que fica evidente quando, em estágios avançados, o indivíduo deixa de se relacionar adequadamente com a sociedade. Cabe à escola, onde o aluno passa grande parte de seu tempo, em atividades acadêmicas, sociais e esportivas, estar atenta aos sinais precoces de comportamentos que sugiram repercussões sobre a saúde, ou a dependência e, assim, poder atuar. Um dos sinais, a ausência na escola, mostra a dificuldade do estudante em diferentes aspectos que poderiam incluir o uso de drogas. O absenteísmo é um indicador de necessidade de intervenção, assim como a diminuição do rendimento escolar ou alterações nos relacionamentos acadêmicos (Tavares et al., 2001).

Considerando que o consumo de drogas faz parte da realidade social - e aqui a realidade pesquisada é constituída por universitários e instituições de ensino superior -, gestores, professores e estudantes convivem com esse problema. Entre os jovens, os universitários se configuram como um grupo especial de investimento científico, sobretudo devido às funções que deverão exercer na sociedade e ao desenvolvimento do País como um todo. O trabalho preventivo moderno determina a participação da escola. Esse trabalho se baseia em três linhas de atuação: aumento do controle social, oferecimento de alternativas e educação (Santos, 1997). Como os jovens passam pelas instituições de ensino superior em idade e situações favoráveis à assimilação de novos hábitos e conhecimentos, a escola é um local especial para implantação de programas de prevenção (Tavares et al. 2001). A publicação "School-based drug abuse prevention" (2009), da Public Safety (Canadá), por exemplo, mostra a importância da escola no enfrentamento do consumo de drogas. 


\subsection{Programas de prevenção do consumo de drogas em escolas de ensino superior}

A permissividade do uso de drogas (nos campi universitários), associada à falta de informações sobre o tema, tem incentivado o desenvolvimento de várias estratégias de prevenção e tratamento. Em geral, essas estratégias têm por objetivos: (a) mudar o conhecimento, as atitudes e os comportamentos dos universitários em relação ao tema drogas; (b) eliminar ou modificar os fatores ambientais que têm contribuído para o problema; (c) proteger os universitários dos impactos negativos decorrentes do uso de drogas e, finalmente, (d) intervir e tratar estudantes que apresentem evidências de problemas decorrentes desse uso (DeJong \& Langford, 2002). Diversos modelos e abordagens vêm sendo utilizados, refletindo o componente multidimensional dos problemas a ele associados, com raízes nos campos médico, psicológico, social, antropológico, espiritual, etc.

Desde a década de 70 têm aumentado (Blume, 1997) os programas de prevenção do abuso de substâncias psicoativas na faculdade e nos campi. $O$ consumo problemático do álcool e outras drogas pelos universitários e a necessidade de sua redução levaram ao desenvolvimento de um plano estratégico, no sentido de orientar os programas desenvolvidos pelas instituições de ensino superior. Nos Estados Unidos, Muraskin (1993), com patrocínio do U S Departament of Educacion, elaborou um manual para orientar a avaliação e nortear a elaboração de programas de prevenção. O autor discute o que é avaliação, como e por que avaliar os projetos de prevenção ao uso de álcool e drogas. Em 2008 foi publicado pelo Office of Safe and Drugs-free Schools - U. S. Departament of Education - um estudo que descreve as políticas e os programas adotados em diferentes instituições de ensino superior que tiveram um resultado favorável em relação à diminuição do consumo de álcool e outras drogas e suas consequências, mostrando que esses programas e políticas têm efeito importante. A avaliação dos programas é importante para determinar sua eficácia para todos os participantes; verificar se os objetivos do programa foram 
cumpridos; fornecer informações sobre a prestação de serviços que serão úteis; programar funcionários e outros participantes e habilitar a equipe do programa para fazer mudanças que possam melhorar eficácia do programa.

Nos Estados Unidos, o Departamento de Educação começa, em 1988, a financiar programas de prevenção ao abuso de drogas nos campi universitários, estimulando inovações na prática dos projetos, e, em 1997, publica um manual para orientar os programas, lembrando que as tentativas de redução ou eliminação dos problemas que acompanham o uso de drogas foram usadas por diferentes culturas durante muito tempo, e incluem punição, tratamento e prevenção (Blume, 1997).

Desde 1999, o Ofice of Safe and Drug-Free Schools, do US Departament of Education (Model Programs, 2008), avalia e concede prêmios aos programas considerados inovadores. Esses modelos são divulgados para outros campi onde o programa possa ser adaptado e replicado (Model Programs, 2008). A instituição deve ainda avaliar o seu projeto e demonstrar que o programa ou política implantada foi eficaz na redução dos problemas decorrentes do uso de álcool e outras drogas.

A experiência na prevenção de drogas em universidades no Reino Unido é descrita por Polymerou (2007), que afirma que os estudantes, em sua maioria, consomem drogas antes de entrar na universidade, mas uma quantidade grande começa a consumir depois de entrar e que, embora diferentes trabalhos indiquem a relação entre consumo de drogas e baixo desempenho acadêmico, são necessários novos estudos. Afirma ainda que os ambientes universitários têm uma posição privilegiada no papel de evitar o uso indevido e nocivo dessas substâncias. Essa atividade de prevenção pelas universidades não é uma exigência legal no Reino Unido e depende, principalmente, da vontade da instituição Em 2004 é lançado um guia (Drugscope Alcohol Concern) para orientar e apoiar as melhores práticas na prevenção.

As universidades utilizam uma variedade de métodos com o pessoal da própria instituição, buscando parcerias, e, embora campanhas de sensibilização tenham sido utilizadas, pouco se sabe sobre a sua eficácia. Polymerou (2007) afirma, ainda, que não existem evidências de que esses programas sejam de boa 
qualidade, e que mais esforços devem ser usados pela universidade na prevenção do consumo de drogas.

Em 2000 foi feita uma revisão de literatura (Walters et al.,2000) com a finalidade de analisar, nas universidades americanas, programas de prevenção do consumo de álcool, e a conclusão foi de que são geralmente ineficazes os programas que se baseiam apenas em informações sobre o uso e a abstinência de drogas - um programa de prevenção para dar bons resultados deve ser abrangente e incluir não só os alunos, mas toda a comunidade acadêmica com ações que, além de permear as atividades com equipes bem treinadas, incluam equipes de saúde multiprofissionais atuando nas organizações esportivas, nos eventos e na moradia dos estudantes.

\subsection{Programas de prevenção ao consumo de drogas e o ensino superior no Brasil}

Mariz et al. (2003) chamam a atenção sobre a verdadeira influência que o meio universitário teria na iniciação ou no aumento do uso de drogas entre os jovens. Consideram como fatores de risco "a maior sensação de liberdade e independência experimentada pelo jovem ao ingressar na faculdade" e o estresse pelos desafios, pela necessidade de superação e pela competição constantes. Afirmam que qualquer ação preventiva precisa estar fundamentada em ampla discussão sobre o tema e desprovida de "clichês sociais, estereótipos ou dogmas" e que cada tópico deve ser intensamente debatido com toda a comunidade universitária.

No Brasil, embora diversos trabalhos tenham sido publicados a respeito de pesquisas sobre o uso de álcool, tabaco e outras drogas entre estudantes universitários, poucos são os que ultrapassam os dados de prevalência e relatam ou avaliam programas de prevenção implantados nos campi.

Mariz (2003) aborda o tema prevenção nas escolas, incluindo as universidades. Orienta para caminhos de implantação de projetos a partir de uma vontade institucional, da definição da política institucional, da composição de uma 
equipe de coordenação, baseadas na realidade da IES (diagnóstico a partir de inquérito epidemiológico), de ações de sensibilização e da formação de multiplicadores tendo um projeto específico para a realidade local.

O trabalho de Simão et al. (2008) relata a experiência de uma universidade brasileira. Conclui que essa é uma tarefa difícil, mas que o programa, cujo objetivo é a diminuição do consumo excessivo do álcool, é bem aceito pelos estudantes.

A questão que emerge dessa discussão é: em quantas escolas existe um projeto de prevenção, orientação e/ou assistência dirigido ao corpo discente e que tem como eixo norteador o consumo de álcool, tabaco e outras drogas? $\mathrm{E}$, nas escolas em que esse programa existe, como ele está estruturado?

$\mathrm{Na}$ análise dos projetos direcionados ao problema do consumo de drogas, os três aspectos podem ser observados, com diferentes aprofundamentos em suas ações. Entende-se que a prevenção constitui conjunto de medidas ou preparação antecipada de (algo) que visa prevenir (dispor com antecipação de modo que se evite mal ou dano, impedir, avisar, informar com antecedência); que, na orientação, a ação vai além da informação, e consiste na prescrição da maneira de organizar-se algo, instrução, regra, assim como modelo que inspira uma pessoa, diretriz, guia, ato ou efeito de orientar (encaminhar, guiar, influenciar), e que a assistência significa ato ou efeito de proteger, amparar, de auxiliar, socorro médico (Houaiss, 2009). Um aspecto não exclui o outro, ao contrário, são complementares, contribuindo para que diferentes olhares trabalhem no enfrentamento do problema nos campi.

É importante situar o ensino superior no Brasil. São diferentes instituições, públicas e privadas, que vão de universidades (múltiplos campi) a faculdades isoladas. As atividades dessas instituições se assentam na tríade ensino, pesquisa e extensão, os eixos norteadores para todas as ações educativas. ${ }^{1}$

\footnotetext{
${ }^{1}$ O conceito de educação considerado aqui é aquele proposto por Salviani (1992) "o ato educativo é o ato de produzir direta e intencionalmente, em cada sujeito singular, a humanidade que é produzida histórica e coletivamente pelo conjunto dos homens."
} 
A Lei de Diretrizes e Bases da Educação - LDB - (Lei Federal n. 9394 de 20 de dezembro de 1996) valoriza esses três aspectos quando, em seu art. 43, fala das finalidades da educação superior.

O ensino e a pesquisa devem estar relacionados, e a extensão é a contrapartida que as instituições devem oferecer à sociedade na qual está inserida. Configura-se como um espaço no qual os alunos podem encontrar a realidade, representada pela comunidade/sociedade no entorno e no interior da escola. Considera-se o campus como um espaço de trabalho, convivência e qualidade de vida para alunos, professores e funcionários, e de integração com a comunidade.

Por outro lado, as demandas dessa comunidade/sociedade devem nortear as opções de ensino, pesquisa e de projetos - extensão/assistência (Tamosauskas, 2003). A escola configura-se como lócus privilegiado para que valores, atitudes e comportamentos sejam estimulados e desenvolvidos.

Entre as recomendações da UNESCO na Declaração Mundial sobre a Educação Superior, produto da Conferência Mundial sobre a Educação Superior no século XXI - Visão e ação, 1998, Paris -, destaca-se que é considerada prioridade do Ensino Superior contribuir para a definição e o tratamento dos problemas que afetam o bem-estar das comunidades, das nações e da sociedade mundial. Entre os problemas que afetam essas instâncias e, de um modo particular, a comunidade acadêmica, encontra-se o tema deste estudo: o consumo de álcool, tabaco e outras drogas pelos estudantes de ensino superior.

No VII Encontro Nacional do fórum de pró-reitores de extensão das universidades públicas, realizado em Cuiabá (Universidade Federal do Mato Grosso), em 1993, com o tema a "Avaliação da Extensão no contexto da Autonomia Universitária", foram estabelecidos alguns princípios em relação à extensão universitária: processo educativo, cultural e científico. Ela deve caminhar articulada com o ensino e a pesquisa; deve articular as relações entre a comunidade acadêmica e a sociedade no sentido da transformação social. Como é uma prática acadêmica, deve dirigir seus interesses para as grandes questões sociais do País e àquelas demandadas pelas comunidades regionais e locais. 
Esses princípios colocam a discussão e enfrentamento do consumo de drogas entre um dos temas a serem incluídos em projetos de extensão.

Desse modo, as diretrizes consideradas para uma extensão de qualidade são as seguintes: interação dialógica, interdisciplinaridade e inter-profissionalidade, indissociabilidade ensino-pesquisa-extensão, impacto na formação do estudante e transformação social. A própria Universidade, parte da sociedade, também deve sofrer impacto e ser transformada. (Nogueira, 2000).

Essa responsabilidade, social e pedagógica, pressiona a escola para uma ação. Carlini-Contrim (1998), ao discorrer sobre o tema drogas na escola, diz que: "A intensa preocupação dedicada ao tema do abuso de drogas entre os jovens vem atualmente constituindo um terreno propício para o desenvolvimento de ações pressionadas para serem preventivas, improvisadas e acríticas. A escola intransigente, eficiente e rápida diante de um problema que se acredita cada vez mais fora de controle, é palco privilegiado dessas ações, algumas vezes quase grotescas, desenvolvidas por profissionais muitas vezes mais aflitos do que propriamente cientes do que estão fazendo." (p.19)

A prevenção nas escolas deve ser planejada a partir de ações concretas, com a finalidade de diminuir os riscos associados ao uso de drogas. Nesse sentido, Carlini-Contrim (1998) apresenta cinco modelos:

- modelo do conhecimento científico, que se baseia do fornecimento de informações que poderiam ser o alicerce par decisões racionais e fundamentadas sobre as drogas e seu uso;

- modelo do conhecimento científico, que se baseia do fornecimento de informações que poderiam ser $\mathrm{o}$ alicerce para decisões racionais e fundamentadas sobre as drogas e seu uso;

- modelo da educação afetiva, baseado em técnicas que visam desenvolvimento da autoestima, capacidade de lidar com a ansiedade, habilidade de decidir e interagir em grupo, comunicação verbal e capacidade de resistir às pressões do grupo;

- modelo de oferecimento de alternativas, estimulando crescimento pessoal, excitação, desafio e alívio ao tédio, propiciando sensações com atividades 
paralelas, tais como orientação pelos alunos mais velhos, esportes, atividades artísticas não diretivas;

- modelo de educação para a saúde visando a qualidade de vida e saúde do estudante;

- modelo de modificação das condições de ensino, visando a formação global, com tendência a envolver os pais e a comunidade. Esse modelo inclui: modificações das práticas institucionais, melhoria do ambiente escolar, incentivo ao desenvolvimento social e oferecimento de serviços de saúde.

À escola, local privilegiado do exercício da educação, "cabe fornecer os mapas de um mundo complexo e constantemente agitado e, ao mesmo tempo, a bússola que permita navegar através dele" (Delors, 2000). Apenas um projeto de prevenção plural, com ações em diferentes frentes, instrumentaliza o estudante para o enfrentamento do problema do consumo de drogas. Na mesma direção apontada por Carlini-Contrim, o relatório elaborado por Delors (2000) para a UNESCO mostra a necessidade de diferentes aspectos de conhecimento que devem permear a formação do homem: aprender a conhecer, aprender ao longo da vida; aprender a fazer - praticamente indissociável do anterior e ancorado nele; aprender a viver junto - reconhecer o outro, perceber as interdependências e gerir conflitos inclui a não violência, a solidariedade, viver em grupo respeitando e sendo respeitado; e, por último, aprender a ser - contribuição ao desenvolvimento total da pessoa como indivíduo ético e crítico.

Essas formas de aprender devem inspirar e orientar as decisões educativas na elaboração de programas e definição de políticas pedagógicas. Um programa de prevenção eficiente precisa considerar, no seu planejamento, execução e avaliação, as características da população para quem é dirigido o programa e sua interação com o ambiente que frequenta (Queiróz, 2010; Carlini, 2010).

Essas ações se completam, de modo que a intervenção não deve estar focada apenas no estudante, mas também no seu entorno, estendendo as discussões para o âmbito das politicas educacionais e métodos pedagógicos. A prevenção do consumo de drogas na escola não deve se basear em eventos esporádicos, mas em um programa contínuo e consistente com ações a curto, médio e longo prazos (Moriz, 2003) e ser avaliado continuamente. 
O Projeto Pedagógico e o Plano de Desenvolvimento Institucional, mais que documentos a serem entregues aos órgãos reguladores, devem se caracterizar como instrumentos de compromisso da ação política e pedagógica.

A Lei de Diretrizes e Bases da Educação Nacional (LDB) no 9.394/96, artigo 12, inciso I, diz que "os estabelecimentos de ensino, respeitadas as normas comuns e as do seu sistema de ensino, têm a incumbência de elaborar e executar sua proposta pedagógica", determinando que a escola deva refletir e planejar sua ação educativa, o que passou a ser um pré-requisito para a renovação do reconhecimento dos cursos e recredenciamento das instituições. O termo "político", que faz parte desse processo, implica que cada escola deve assumir sua concepção de homem, mundo, educação e sociedade desse modo. "O projeto político-pedagógico de uma escola é um processo de tomada de consciência dessa escola" (Buttura, 2005). Sua importância é que ele passa a ser um rumo, uma orientação para as ações da escola, definindo os propósitos e compromissos.

O perfil da instituição, sua missão e objetivos devem ser especificados em dois documentos que legalmente são apresentados aos órgãos reguladores do ensino superior: Ministério de Educação e Cultura (MEC) e/ou Conselhos Estaduais, conforme o regime administrativo da instituição, e que determinam parâmetros para sua construção: o Projeto Pedagógico Institucional (PPI) e o Plano de Desenvolvimento Institucional (PDI). O projeto ou plano, teoricamente, permite àquele que o possui uma antecipação do que se pode e se quer alcançar, viabilizando o trabalho por ações orientadas para o objetivo.

A palavra projeto deriva etimologicamente do latim projectus - ação de lançar para frente - e, segundo o dicionário Houaiss, significa desejo, intenção de realizar. Esses sentidos da palavra projeto nos alertam que, sendo um movimento para a frente, esse movimento é de recriação que parte do agora já construído e que, por ser histórico, pode ser transformado. Nas palavras de Gadotti (2000), "um projeto necessita rever o instituído para, a partir dele, instituir outra coisa, tornar-se instituinte".

O Projeto Político-Pedagógico revela um compromisso e uma intencionalidade, é norteador da formação do aluno (profissional e cidadão) e deve articular os três âmbitos de atuação da escola. Segundo André (2001), deve 
"expressar a reflexão e o trabalho realizado em conjunto por todos os profissionais da escola, no sentido de atender às diretrizes do Sistema Nacional de Educação, bem como às necessidades locais e específicas da clientela da escola" e caracterizar a função social da universidade, que traduz posições pedagógicas, econômicas, filosóficas e interesses que se contradizem no cotidiano. A realidade que a IES vive deve ser a base da construção do PPI. Segundo Freire (2002), "quando o homem compreende sua realidade, pode levantar hipóteses sobre o desafio dessa realidade e procurar soluções. Assim, pode transformá-la e, com seu trabalho, pode criar um mundo próprio: seu eu e suas circunstâncias".

O PPI significa mais que os planos dos cursos da instituição, significa assumir uma posição filosófica que testemunha a missão da instituição e seu perfil, e deve ser vivido por todos os participantes do processo educativo da instituição. Veiga (2003) entende que: "O PPP é um meio de engajamento coletivo para integrar ações dispersas, criar sinergias no sentido de buscar soluções alternativas para diferentes momentos do trabalho pedagógico- administrativo, desenvolver o sentimento de pertença, mobilizar os protagonistas para a explicitação de objetivos comuns, definindo 0 norte das ações a serem desencadeadas, fortalecer a construção de uma coerência comum, mas indispensável, para que a ação coletiva produza seus efeitos” (Veiga, 2003, p.8).

O PPI é um plano global da instituição e, segundo Vasconcellos (1995), pode ser definido como "um instrumento teórico-metodológico que visa ajudar a enfrentar os desafios do cotidiano da escola, só que de uma forma refletida, consciente, sistematizada, orgânica e, o que é essencial, participativa. É uma metodologia de trabalho que possibilita re-significar ação de todos os agentes da instituição."

Segundo Boutinet (2002), a elaboração do PPI deve obedecer a diferentes etapas: análise da situação, determinação das necessidades prioritárias, das carências, das incoerências, das disponibilidades, dos atores envolvidos e das intenções. A análise da situação leva a um diagnóstico - os pontos fortes e as fragilidades da instituição são identificados - e são delineadas as necessidades, as carências, as incoerências e as disponibilidades, que vão levar à elaboração dos objetivos, da metodologia e das ações a serem desenvolvidas. Os atores 
envolvidos, sua capacidade e capacitação, estrutura disponível, bem como a forma de avaliar, são inerentes à construção de um projeto.

O projeto político-pedagógico tem um eixo político, explicado por André (2001): "político no sentido de compromisso com a formação do cidadão para um tipo de sociedade, e pedagógico porque possibilita a efetivação da intencionalidade da escola, que é a formação do cidadão participativo, responsável, compromissado, crítico e criativo", preocupado não apenas com o aluno que queremos formar, mas com qual será sua inserção no mundo, seu papel transformador. Para Freire (2002), "a educação é uma forma de intervenção no mundo" e, portanto, a responsabilidade da IES vai além de transmitir conteúdos: deve preparar cidadãos para a vida e para transformar o mundo em que vivem, fazendo parte do processo de construção histórica em uma sociedade cada vez mais complexa.

A organização da escola como um todo, a organização das atividades em sala de aula e a relação com o contexto social imediato são, portanto, olhares que permeiam a construção do projeto político-pedagógico (Veiga, 2001). É nesse projeto que todas as ações de ensino, pesquisa e extensão devem estar articuladas. O PPI deve nascer da realidade da instituição, baseado na análise das causas dos problemas e das situações em que os problemas aparecem, ser de possível execução, prever as condições para seu desenvolvimento e avaliação (Stocco, 2005). ${ }^{2}$

O Plano de Desenvolvimento Institucional (PDI) se caracteriza como um outro documento, que é um compromisso com o Ministério da Educação, e se orienta para o controle e a estabilidade da instituição por meio de ações de curto prazo (Veiga, 2003). É obrigatório desde 2008 pela Lei 11892 de 29/12/2008, deve apresentar a forma como a IES pretende concretizar seu projeto educacional, definir metas a serem alcançadas em tempos definidos, recursos humanos e materiais para a manutenção e o desenvolvimento das ações propostas. Deve incluir o PPI e, portanto, estar articulado com ele.

\footnotetext{
${ }^{2}$ Considera-se aqui o consumo de drogas pelos estudantes um problema que deve ser diagnosticado e estudado, e estabelecido um caminho de enfrentamento contínuo enquanto processo.
} 
Segundo as Diretrizes para Elaboração do PDI, publicadas pela Secretaria de Educação Profissional e Tecnológica da Secretaria de Educação Superior do Ministério da Educação, o "Plano de Desenvolvimento Institucional - PDI, elaborado para um período de 5 (cinco) anos, é o documento que identifica a Instituição de Ensino Superior (IES) no que diz respeito à sua filosofia de trabalho, à missão a que se propõe, às diretrizes pedagógicas que orientam suas ações, à sua estrutura organizacional e às atividades acadêmicas que desenvolve e/ou que pretende desenvolver". Entre seus eixos temáticos temos a gestão institucional, na qual deve ser destacada a política de atendimento ao discente e explicitadas as ações de apoio e estímulo à permanência discente, que, entre outros aspectos, pode incluir projetos de prevenção, assistência, orientação e/ou tratamento relativos ao consumo indevido de álcool, tabaco e outras drogas.

Diante do exposto, pode se considerar que os estudos sobre o papel que as IES têm desempenhado mostram que elas não respondem às necessidades de intervenção.

Conscientes do papel social da escola e da responsabilidade na formação integral de seu aluno (conhecimentos, habilidades e atitudes), questionamos se 0 tema (consumo de álcool, tabaco e outras drogas, lícitas e ilícitas) é incluído nos Projetos Pedagógicos Institucionais ou nos PDls e desenvolvemos este presente projeto. Ele faz parte do I Levantamento Nacional Sobre o Uso de Álcool, Tabaco e outras Drogas entre Universitários das 27 Capitais Brasileiras, constituído pelos temas: 1. dados sócio-demográficos; 2 . prevalência e padrão de uso do tabaco e outras substâncias psicoativas; 3. prevalência e padrão de uso de álcool; 4. uso múltiplo de drogas; 5 . uso de drogas na Universidade de São Paulo; 6. prevalência de comportamentos de risco; 7. saúde mental; 8. comparação do uso de drogas entre os universitários e outros segmentos sociais e 9. políticas institucionais sobre drogas nas IES.

O subprojeto nove, que tinha como meta tema as políticas institucionais sobre drogas nas IES, foi desenvolvido sob minha responsabilidade, e dados novos, bem como o aprofundamento dos dados anteriormente apresentados, deram origem a esta tese de doutorado. 
Ela apresenta o perfil dos universitários frente ao consumo de álcool e outras drogas, as implicações desse uso sobre sua saúde e seu desempenho acadêmico, bem como comportamentos de risco associados.

Sua elaboração foi possível através de uma parceria entre a Secretaria Nacional de Políticas sobre Drogas (SENAD) do Gabinete da Segurança Nacional da Presidência da República e o Grupo Interdisciplinar de Estudos de Álcool e Drogas (GREA) da Faculdade de Medicina da Universidade de São Paulo. 
A LIBERTAÇÃO DOS INDIVÍDUOS SÓ GANHA PROFUNDA SIGNIFICAÇÃO QUANDO SE ALCANÇA A TRANSFORMAÇÃO DA SOCIEDADE. O SONHO SE FAZ DE uMA NECESSIDAde, UMA PRECISÃO. PAulo Freire, PedAGOGIA DA ESPERANÇA, 1992 


\subsection{Objetivo principal}

- Investigar como o consumo de drogas pelos estudantes universitários é tema dos projetos institucionais nas Instituições de Ensino Superior do Brasil.

- Identificar e analisar o perfil dos programas de prevenção, orientação e/ou assistência ao corpo discente existentes nas Instituições de Ensino Superior do Brasil.

\subsection{Objetivos secundários}

- Conhecer a percepção dos alunos sobre a existência de ações de apoio à saúde, informações e ajuda sobre o consumo de drogas em suas Instituições de Ensino Superior.

- Identificar e avaliar os projetos com a temática do consumo de drogas pelos estudantes existentes nos sites oficiais das Instituições de Ensino Superior do Brasil.

- Avaliar os programas relacionados ao tema drogas (nas áreas de ensino, prevenção e assistência) das Instituições de Ensino Superior do Brasil.

- Descrever e analisar os programas/projetos relacionados ao tema drogas nas áreas de ensino, prevenção e assistência direcionados aos alunos. 
NINGUÉM CAMINHA SEM APRENDER A CAMINHAR, SEM APRENDER A FAZER

O CAMINHO CAMINHANDO, REFAZENDO E RETOCANDO O SONHO PELO QUAL

SE PÔS A CAMINHAR. PAUlo Freire, Pedagogia da EsperanÇA, 1992 
O I Levantamento Nacional sobre o uso de álcool, tabaco e outras drogas entre universitários das 27 capitais brasileiras foi analisado e aprovado pela Comissão de Ética para Análise de Projetos em Pesquisa - CAPPESq - da Diretoria Clínica do Hospital das Clínicas da Faculdade de Medicina da Universidade de São Paulo (protocolo de pesquisa n. 0378/08) em sessão de 06/08/2008 ( ANEXO A), e o subprojeto, objeto desta tese de doutorado, aprovado pela mesma comissão em 2012. (ANEXO B).

\subsection{Cenário e sujeitos do estudo (AMOSTRA)}

Trata-se de estudo transversal, envolvendo uma amostra das Instituições de Ensino Superior (IES) das 27 capitais brasileiras (Estados e Distrito Federal). A amostra foi estratificada por conglomerados desiguais (quanto ao número de alunos das IES e ao número de alunos por turma). As cinco regiões administrativas (Norte, Nordeste, Centro-Oeste, Sudeste e Sul) foram definidas como um estrato de amostragem, e o tipo de organização administrativa (pública ou privada) como o segundo estrato. Os conglomerados estabelecidos foram as IES e as classes de alunos. O cálculo do tamanho amostral foi definido na elaboração do I Levantamento Nacional sobre o uso de álcool, tabaco e outras drogas entre universitários das 27 capitais brasileiras (Andrade et al., 2010).

A população pesquisada no presente estudo abrange as Instituições de Ensino Superior e seus alunos. Localizadas nas 27 capitais de estados brasileiros, representam as cinco regiões administrativas (Norte, Nordeste, Centro-Oeste, Sudeste e Sul). Em cada uma dessas capitais foi selecionada a participação de pelo menos uma Instituição de Ensino Superior pública e uma privada. Para a seleção dos alunos participantes, dentro de cada IES foi sorteada uma turma de alunos. Desse modo, a IES é a unidade amostral primária, e a turma de alunos é a unidade amostral secundária.

Uma relação com todas as IES existentes foi obtida através de uma solicitação ao Ministério de Educação e Cultura/Instituto Nacional de Estudos e pesquisas educacionais Anisio Teixeira (INEP), e essa relação foi considerada o sistema de referência das IES do estudo, a partir do qual foi realizado o primeiro 
estágio de seleção da amostra, que incluía faculdades, escolas, institutos, faculdades integradas, centros federais de educação tecnológica e faculdades de tecnologia. Nessa relação, constam informações detalhadas das IES, como o nome da instituição e sua localização (Unidade Federativa e cidade). Em 2008 havia 2.252 IES no Brasil e 811 (36\%) delas se localizavam em capitais. O número de estudantes matriculados em cursos de graduação presenciais era de 5.080.056, com 45\% (2.318.204) nas capitais. Na relação enviada pelo MEC/INEP estavam presentes todas as IES do Brasil, mas a população de interesse são apenas as IES das capitais - as que não estavam localizadas em uma capital foram excluídas.

Como as 27 capitais deveriam estar presentes na amostra e, quanto ao regime administrativo, tanto IES públicas quanto privadas deveriam ser contempladas, a estratificação em relação a essas duas variáveis totalizou 54 estratos. Foi definida como amostra a participação de duas IES públicas e duas privadas em cada uma das capitais. Em cada instituição foi selecionada uma turma (classe) de alunos.

O total obtido foi de 103 IES, uma vez que em cinco capitais havia apenas uma instituição pública. Em São Paulo optou-se por selecionar mais IES, com a finalidade de maior variabilidade de respostas serem captadas. Desse modo, foram selecionadas 13 IES, três públicas e dez privadas nesta capital. Essa estratificação foi utilizada apenas para fins de definição da escolha da IES considerada unidade amostral primária.

\subsection{Sorteio da amostra de IES}

Inicialmente foram selecionadas 114 IES - o sistema de referência é separado de acordo com a estratificação mencionada acima e, em cada um dos estratos, duas IES são selecionadas, exceção das capitais de Rondônia, Acre, Amapá, Sergipe e Mato Grosso do Sul, em que havia apenas uma IES pública, e na capital de São Paulo, em que foram selecionadas três IES públicas e dez privadas. Com o intuito de utilizar as informações contidas no sistema de 
referência, ordenado separadamente para cada estrato, o sorteio foi realizado através de uma seleção sistemática com ponto inicial aleatório.

Uma vez selecionada a IES, foi feito contato com a sua direção, solicitando autorização para a participação e a designação de um interlocutor que pudesse fornecer dados sobre a instituição. Cem instituições de ensino superior, 52 públicas e 48 privadas, aceitaram participar da pesquisa.

\subsection{Sorteio da amostra de turma de alunos}

Uma segunda etapa foi o sorteio das turmas. Para isso, foi solicitado aos gestores de cada uma das IES que concordaram em participar da pesquisa, uma lista de disciplinas obrigatórias presenciais de todos os cursos no campus da capital, e essa lista foi separada por ano letivo, período e área de estudo. As turmas/classes foram selecionadas por sorteio sistemático. Todos os alunos das classes sorteadas foram convidados a participar voluntariamente do estudo. Nesta segunda fase de sorteio, cada IES tinha um quadro de amostragem próprio. O número de alunos selecionados foi proporcional ao total de alunos daquela IES.

\subsection{Instrumentos de pesquisa}

\subsubsection{Questionário a ser respondido pelos alunos}

O questionário estruturado respondido pelos alunos era anônimo, de autopreenchimento e individual, e constituído por cinco perguntas com respostas fechadas, que corresponderam aos temas de interesse do estudo (existência, utilização do programa de assistência à saúde, acesso à informações sobre drogas, apoio institucional). É importante ressaltar que essas questões (números de 73 a 77, Anexo C) faziam parte de um questionário com 98 questões, correspondentes ao I Levantamento Nacional sobre o uso de álcool, tabaco e outras drogas entre universitários das 27 capitais brasileiras. Junto com 0 questionário, o aluno recebeu o Termo de Consentimento Livre e Esclarecido. $\mathrm{Na}$ 
devolução, os dois documentos foram depositados em urnas diferentes, para preservar o anonimato do estudante.

Os questionários tiveram sua digitação eletrônica efetuada por uma equipe especializada, e o software SPSS Data Entry foi usado na construção do banco de dados, que foram exportados no formato .sav do SPSS versão 13.1 para Windows. Uma equipe de aplicadores da empresa de pesquisa IPSOS Public Affairs conduziu essa coleta dos dados em todas as capitais (Andrade, 2010).

\subsubsection{Questionário a ser respondido pela instituição}

O segundo instrumento da coleta de dados foi um questionário semiestruturando para ser respondido pelos representantes das IES designados pelo corpo diretivo da instituição. Esse questionário tinha por finalidade identificar a existência de programa de prevenção, orientação ou assistência sobre o uso de álcool, tabaco e outras substâncias psicoativas, direcionado ao corpo discente. Os representantes designados pelas instituições foram contatados pessoalmente, por e-mail e telefone, e receberam o formulário para ser respondido pessoalmente ou por via eletrônica sobre a existência de programas que apresentavam esse enfoque (Anexo D).

A utilização de dois instrumentos - pesquisa aos sites e questionário - para a obtenção de um mesmo dado (existência, ou não, de programas institucionais) caracteriza uma metodologia de triangulação de dados. Chamamos triangulação quando diferentes métodos para coleta de dados são utilizados para obtenção de um mesmo dado, como uma estratégia para testar a validade e a confiabilidade da pesquisa (Golafshani, 2003).

\subsubsection{Pesquisa nos sites}

Como sistematização para a coleta de dados, com a finalidade de conhecer a existência de programas/projetos voltados para a prevenção, orientação e/ou assistência ao corpo discente em relação ao uso de álcool, tabaco e outras drogas, foi usada como ferramenta a pesquisa na internet através dos sites/portais 
da Instituição de Ensino Superior (IES), tendo como endereço (URL) o site oficial de cada uma das 100 instituições. Esse instrumento foi utilizado de forma independente por dois pesquisadores experientes nesse tipo de busca.

A primeira fase da busca teve como objetivo percorrer o site segundo a visita e a visão de um usuário comum. Seguindo a interface apresentada no site de cada instituição, o menu de navegação principal foi identificado e percorrido na íntegra em busca de algum programa ou projeto de prevenção, orientação ou assistência aos alunos em relação ao uso de drogas. Nos casos das instituições cujos sites continham sub-homes e menus de navegação internos, a pesquisa prosseguiu até que algo fosse encontrado ou se esgotassem as possibilidades de exploração do site.

Uma segunda estratégia de coletar esses dados foi a utilização de mecanismos de busca interna oferecidos pelo próprio site, tendo como palavraschave: programa, prevenção, orientação, assistência, álcool, cigarro e drogas. Deve-se notar que, em alguns casos, os sites das instituições não apresentam ao visitante nenhum mecanismo de pesquisa, impossibilitando a busca tanto aos pesquisadores deste trabalho como aos usuários regulares.

Terceiro momento da pesquisa nos sites das IES selecionadas ocorreu com a utilização de um mecanismo de busca avançada, externa ao site, com as mesmas palavras-chave. Isso é importante não apenas porque muitos sites não possuem mecanismo de busca interna - ou, se possuem, podem ser pouco eficientes -, não retornando todo o conteúdo que realmente existe no site. Por essa razão, optou-se pelo uso do mecanismo de busca do Google (google.com), que mapeia todo o conteúdo dos sites. Para isso, os pesquisadores usaram expressões de buscas no Google que filtram sua busca global para um único domínio, ou seja, apenas ao site da IES, como no exemplo abaixo:

site: www.instituição.br "álcool"

Todos os resultados obtidos foram catalogados para análise posterior. Nessa pesquisa, a publicação de notícias sobre drogas lícitas e ilícitas nos sites e também a realização de eventos pontuais sobre álcool, tabaco ou outras drogas não caracterizaram a existência de um programa a respeito. 
É importante salientar que, em metodologias de pesquisa qualitativa, esse processo de dupla pesquisa com os mesmos instrumentos é uma forma de validação interna dos dados obtidos, sempre que os dados coletados sejam muito próximos. Neste caso específico, os dados foram semelhantes, não houve discrepância. Os dados foram coletados entre maio e dezembro de 2009.

\subsection{Análise do perfil dos programas institucionais}

Constatada a existência de programa de prevenção, orientação e/ou assistência sobre o uso de álcool, tabaco e outras drogas, por um dos instrumentos usados (questionário ou busca no site), foi solicitado ao representante da instituição (via telefonema e e-mail) o envio de uma cópia do programa, para análise documental. A análise de documentos é uma das técnicas de obtenção de dados na pesquisa qualitativa. Entende-se aqui como documento o registro por escrito que possa ser usado como fonte de informação. Segundo Cunha (2010), "declaração escrita para servir de prova". Os documentos analisados neste estudo foram os projetos institucionais disponibilizados e as respostas escritas das questões abertas do questionário respondido pelos representantes designados pela IES.

Os dados obtidos foram analisados em termos dicotômicos (sim/não) em relação à existência dos programas e outras questões fechadas e as questões abertas foram analisadas pela técnica qualitativa de análise do conteúdo (Bardin, 2002), técnica usada para analisar textos. O objetivo principal da análise do conteúdo consiste em classificar sistematicamente palavras, frases, sentenças e outras unidades de texto em uma série de categorias significativas (Kalof et al., 2008).

Finalmente, os programas enviados e os obtidos no site tiveram suas características analisadas através de técnica de metodologia qualitativa, a análise de conteúdo, definida por Bardin (2002) como um conjunto de técnicas de análise de comunicações que utiliza procedimentos sistemáticos e objetivos de descrição do conteúdo das mensagens (no caso documentos), que permitam a inferência de conhecimentos relativos às condições de produção/recepção dessas mensagens e 
que se preocupam com um nível de realidade que não pode ser quantificado, buscando compreender as características, estruturas e/ou modelos.

O tratamento do material coletado (os projetos), como fase indispensável no processo de análise para o desenvolvimento da pesquisa, foi a leitura do material para início da categorização das unidades de análise. De início foi realizada uma "leitura flutuante" (Turato, 2003), na qual não se privilegia nenhum componente, e que se faz necessária para uma aproximação com o texto.

Feita a leitura dos documentos na fase inicial, como segundo passo, foi feita a releitura do material com mais atenção, já conhecendo previamente seu conteúdo, com a finalidade de revisão das categorias propostas, que é um estágio intermediário de categorização (detecção de unidades de significado em um texto), e de "preservar o material" que não se enquadra em nenhuma das unidades ou categorias criadas ou fora do tema objeto desta pesquisa, impedindo que este seja perdido.

Obtivemos, desse modo, depois de idas e vindas aos documentos, as seguintes categorias: ano de implantação do projeto, inclusão no PDI (Plano de Desenvolvimento Institucional) ou no PPI (Projeto Político Institucional), público a que se destina, objetivos, ações previstas e avaliação, as quais, durante a análise, se desdobraram em subcategorias.

A finalidade dos métodos quantitativos e qualitativos é chegar ao melhor resultado para entendimento do problema levantado pela pesquisa. A escolha de um deles depende da natureza do problema, e talvez uma forma simples de diferenciá-los seja dizendo que a pesquisa quantitativa usa ferramentas estatísticas para ajudar a entender os dados obtidos, enquanto a pesquisa qualitativa procura entender os dados sem o uso dessas ferramentas, confiando na capacidade de o pesquisador observar padrões (Kalof et al., 2008) e eleger categorias.

Os estudos qualitativos não pretendem medir, nem associar as medições a números (observação, questionário/entrevista aberta, revisão de documentos, discussão em grupos, história de vida, entre outros), nem são, geralmente, analisados estatisticamente, embora a análise possa incluir expressões numéricas. "Por sua vez, a pesquisa qualitativa dá profundidade aos dados, a dispersão, a 
riqueza interpretativa, a contextualização do ambiente, os detalhes e as experiências únicas" (sic) (Sampiere et al., 2006). 
NO FUNDO NINGUÉM CHEGA LÁ, PARTINDO DE LÁ, MAS DE CERTO AQUI. ISSO SIGNIFICA EM ÚLTIMA ANÁLISE, QUE NÃO É POSSÍVEL AO (A) EDUCADOR (A) DESCONHECER, SUBESTIMAR OU NEGAR OS “SABERES DE EXPERIÊNCIAS FEITAS” COM Que os EduCANdos chegam À escola. Paulo Freire, Pedagogia DA ESPERANÇA, 1992. 


\subsection{Descrição da amostra}

\section{Instituições}

A amostra pesquisada é formada por 100 Instituições de Ensino Superior (IES, constituídas por universidades, institutos e faculdades isoladas) que aceitaram participar da pesquisa. Localizadas nas capitais dos Estados, elas foram sorteadas e representam as escolas públicas e privadas das cinco regiões geográficas do Brasil.

Tabela 1: Distribuição das IES por região geográfica e regime administrativo. $\mathrm{N}=100$

\begin{tabular}{|l|c|c|c|}
\hline \multicolumn{2}{|l|}{ POR REGIÃO E REGIME } & & \\
\hline & PRIVADAS & PÚBLICAS & Total \\
\hline Norte & $13(13 \%)$ & $11(11 \%)$ & $24(24 \%)$ \\
\hline Nordeste & $17(17 \%)$ & $15(15 \%)$ & $32(32 \%)$ \\
\hline Centro-Oeste & $6(6 \%)$ & $7(7 \%)$ & $13(13 \%)$ \\
\hline Sudeste & $11(11 \%)$ & $9(9 \%)$ & $20(20 \%)$ \\
\hline Sul & $5(5 \%)$ & $6(6 \%)$ & $11(11 \%)$ \\
\hline Total & $\mathbf{5 2 ( 5 2 \% )}$ & $\mathbf{4 8 ( 4 8 \% )}$ & $\mathbf{1 0 0 ( 1 0 0 \% )}$ \\
\hline
\end{tabular}

As IES estão localizadas nas capitais dos Estados brasileiros, apresentando a seguinte distribuição: $24 \%$ nas capitais dos Estados da região Norte: $32 \%$ no Nordeste, $13 \%$ na região Centro-Oeste, $20 \%$ no Sudeste e 11\% no Sul, sendo, como regime administrativo, $52 \%$ privadas e $48 \%$ públicas. 
Tabela 2: Distribuição das IES participantes por número de cursos oferecidos e regime administrativo. $\mathrm{N}=100$

\begin{tabular}{|c|c|c|c|}
\hline Número de Cursos & PÚBLICAS & PRIVADAS & Total \\
\hline 1 A 10 & 3 & 18 & $21(21 \%)$ \\
\hline $\mathbf{1 1}$ A 20 & 7 & 7 & $14(14 \%)$ \\
\hline 21 A 50 & 17 & 20 & $37(37 \%)$ \\
\hline + 50 & 21 & 7 & $28(28 \%)$ \\
\hline TOTAL & 48 & 52 & $100(100)$ \\
\hline
\end{tabular}

As escolas selecionadas apresentavam variedade em relação ao número de cursos: $21 \%$ das escolas ofereciam até dez cursos, sendo que em nove dessas instituições havia cursos na área de saúde; $14 \%$ das instituições apresentavam entre 11 e 20 cursos (seis instituições com cursos na área de saúde); 37\% entre 21 e 50 cursos (33 instituições com cursos na área da saúde) e $28 \%$ instituições ofereciam mais de 50 cursos (27 instituições com cursos na área de saúde). No total das escolas que participaram da pesquisa, 75 ofereciam cursos nas áreas biológica e/ou saúde.

\section{Estudantes}

Fizeram parte da amostra 12.711 estudantes do ensino superior, matriculados nas instituições das capitais dos Estados brasileiros, distribuídos pelas cinco regiões administrativas. 
Tabela 3- Distribuição dos estudantes pesquisados por região administrativa

\begin{tabular}{|c|c|}
\hline Região administrativa & Total de alunos \\
\hline Norte & $2.301(18,1 \%)$ \\
\hline Nordeste & $3.203(25,2 \%)$ \\
\hline Centro-Oeste & $2.199(17,3 \%)$ \\
\hline Sudeste & $2.568(20,2 \%)$ \\
\hline Sul & $2.440(19,2 \%)$ \\
\hline Total & 12.711 \\
\hline
\end{tabular}

Entre os alunos que participaram da pesquisa, $48,8 \%$ estão matriculados em instituições públicas e $51,2 \%$ em instituições privadas, apresentando uma distribuição semelhante entre os dois regimes administrativos (tabela 4).

Tabela 4 - Distribuição dos alunos que responderam ao questionário por gênero e regime administrativo da instituição

\begin{tabular}{|l|c|c|c|}
\hline \multirow{2}{*}{ Gênero } & \multicolumn{2}{|c|}{ TIPO DE IES } & \multirow{2}{*}{ Total } \\
\cline { 2 - 4 } & Pública & \multicolumn{1}{|c|}{ Privada } & \\
\hline Masculino & $50 \%$ & $41 \%$ & $43 \%$ \\
\hline Feminino & $50 \%$ & $59 \%$ & $57 \%$ \\
\hline BASE & $\mathbf{6 . 2 0 6}$ & $\mathbf{6 . 5 0 5}$ & $\mathbf{1 2 . 7 1 1}$ \\
\hline
\end{tabular}

Os estudantes eram $59 \%$ do gênero feminino e $41 \%$ do gênero masculino, equitativamente em escolas públicas e em escolas privadas - um número ligeiramente maior de mulheres (tabela 4). 


\subsection{Respostas dos alunos ao questionário}

Os questionários dos alunos não tinham identificação, não sendo possível, desse modo, relacionar suas respostas com as respostas das instituições. Todos os alunos que responderam ao questionário assinaram um Termo de Consentimento Livre e Esclarecido (Anexo E).

As questões referentes à existência de programas, informações fornecidas pelas IES e a possibilidade de encontrar ajuda da IES em relação ao consumo de álcool, tabaco e outras drogas são as de número 73 a 77 do questionário geral aplicado aos alunos no I Levantamento Nacional sobre o uso de álcool, tabaco e outras drogas entre universitários das 27 capitais brasileiras (Andrade et al., 2010) (Anexo C).

\section{Programas de atendimento à saúde}

Tabela 5 - Distribuição das respostas dos alunos em relação à existência de programas de atendimento à saúde discente e sua distribuição por gênero em número absoluto e porcentagem

\begin{tabular}{|l|c|c|l|}
\hline & \multicolumn{2}{|c|}{ Gênero } & \multirow{2}{*}{ Total } \\
\hline Respostas & Masculino & Feminino & \\
\hline Não & $36 \%$ & $36 \%$ & $4.564(36 \%)$ \\
\hline Sim & $56 \%$ & $60 \%$ & $7.353(58 \%)$ \\
\hline Não respondeu & $8 \%$ & $5 \%$ & $760(6 \%)$ \\
\hline Total & 5682 & 6995 & 12.677 \\
\hline
\end{tabular}

Mais de metade dos alunos, $58 \%$, respondeu saber da existência de um programa de atendimento à saúde dos estudantes na instituição, enquanto $36 \%$ responderam que não existe programa de atendimento ao discente e $6 \%$ não 
responderam a questão. A distribuição de respostas foi semelhante para os dois gêneros.

Tabela 6 - Distribuição das respostas em porcentagem quanto à existência de um programa de atendimento à saúde do aluno em relação à região administrativa e tipo de IES

\begin{tabular}{|l|c|c|c|c|c|c|c|c|}
\hline \multirow{2}{*}{ Resposta } & \multicolumn{2}{|c|}{ TIPO DE IES } & \multicolumn{5}{c|}{ REGIÃO ADMINISTRATIVA } & \\
\cline { 2 - 9 } & Pública & Privada & Norte & Nordeste & $\begin{array}{c}\text { Centro- } \\
\text { Oeste }\end{array}$ & Sudeste & Sul & Total \\
\hline Não & $34 \%$ & $36 \%$ & $40 \%$ & $31 \%$ & $33 \%$ & $37 \%$ & $29 \%$ & $\begin{array}{c}4.576 \\
36 \%\end{array}$ \\
\hline Sim & $62 \%$ & $57 \%$ & $54 \%$ & $67 \%$ & $63 \%$ & $55 \%$ & $66 \%$ & $\begin{array}{c}7.372 \\
58 \%\end{array}$ \\
\hline $\begin{array}{l}\text { Não } \\
\text { respondeu }\end{array}$ & $4 \%$ & $7 \%$ & $6 \%$ & $3 \%$ & $5 \%$ & $7 \%$ & $6 \%$ & $\begin{array}{c}763 \\
6 \%\end{array}$ \\
\hline $\begin{array}{l}\text { Total de } \\
\text { alunos }\end{array}$ & $\mathbf{6 . 2 0 6}$ & $\mathbf{6 . 5 0 5}$ & $\mathbf{2 . 3 0 5}$ & $\mathbf{3 . 2 0 0}$ & $\mathbf{2 . 1 9 9}$ & $\mathbf{2 . 5 6 6}$ & $\mathbf{2 . 4 4 1}$ & $\mathbf{1 2 . 7 1 1}$ \\
\hline
\end{tabular}

As respostas dos alunos em relação à presença de programa de atenção à saúde do aluno, por tipo de IES, mostra uma porcentagem de $62 \%$ de respostas afirmativas em instituições públicas e $57 \%$ nas instituições privadas nas diferentes regiões. As regiões Nordeste e Sul apresentam maior porcentagem de respostas afirmativas, enquanto a menor porcentagem aparece no Norte e no Sudeste.

Tabela 7- Distribuição das respostas quanto à existência de um programa de atendimento à saúde do aluno em relação ao curso em que estava matriculado

\begin{tabular}{|l|c|c|c|c|}
\hline \multirow{2}{*}{} & \multicolumn{3}{|c|}{ ÁREA DE ESTUDO } & \multirow{2}{*}{} \\
\cline { 2 - 5 } & $\begin{array}{c}\text { Biológicas/Saúd } \\
\text { e }\end{array}$ & Exatas & Humanas & \multirow{2}{*}{ Total } \\
\hline Não & $23 \%$ & $35 \%$ & $39 \%$ & $\mathbf{4 . 5 7 6 ( 3 6 \% )}$ \\
\hline Sim & $74 \%$ & $56 \%$ & $55 \%$ & $\mathbf{7 . 3 7 2 ( 5 8 \% )}$ \\
\hline $\begin{array}{l}\text { Não } \\
\text { respondeu }\end{array}$ & $3 \%$ & $9 \%$ & $7 \%$ & $\mathbf{7 6 3 ( 6 \% )}$ \\
\hline Total & $\mathbf{3 . 2 1 2}$ & $\mathbf{3 . 2 7 6}$ & $\mathbf{6 . 0 0 7}$ & $\mathbf{1 2 . 7 1 1}$ \\
\hline
\end{tabular}


Em relação à área do conhecimento do curso em que o aluno estava matriculado, $74 \%$ são da área biológica, que inclui os cursos de saúde. conhecem o programa de atendimento à saúde oferecido por suas instituições, porcentagem maior do que as observadas nas outras áreas do conhecimento.

\section{Utilização dos programas de atendimento à saúde do estudante}

Tabela 8- Distribuição das respostas por gênero e tipo de IES em que o aluno está matriculado referentes ao uso do programa de atendimento à saúde dos alunos

\begin{tabular}{|l|c|c|c|c|c|}
\hline \multirow{2}{*}{ Respostas } & \multicolumn{2}{|c|}{ SEXO } & \multicolumn{2}{c|}{ TIPO DE IES } & \multirow{2}{*}{ Total } \\
\cline { 2 - 5 } & Masculino & Feminino & Pública & Privada & \\
\hline Não & $89 \%$ & $88 \%$ & $88 \%$ & $89 \%$ & $\begin{array}{l}\mathbf{6 . 4 8 8} \\
\mathbf{8 8 \%}\end{array}$ \\
\hline Sim & $10 \%$ & $10 \%$ & $12 \%$ & $9 \%$ & $\mathbf{7 3 7}$ \\
& & & & & $\mathbf{1 0 \%}$ \\
\hline $\begin{array}{l}\text { Não } \\
\text { respondeu }\end{array}$ & $2 \%$ & $2 \%$ & $1 \%$ & $2 \%$ & $\mathbf{1 4 7}$ \\
\hline & 3.314 & 4.037 & 3.738 & 3.635 & $\mathbf{2 . 3 7 3}$ \\
\hline
\end{tabular}

Entre os alunos que sabiam da existência de um programa de atendimento à saúde do corpo discente, a maioria, $88 \%$, declarou não fazer uso desse programa. Poucos alunos fazem uso do serviço, $10 \%$. As porcentagens são semelhantes quando considerados gênero e tipo de IES. 
Tabela 9 - Distribuição das respostas por região administrativa em relação ao uso do programa de atendimento à saúde dos alunos

\begin{tabular}{|c|c|c|c|c|c|c|}
\hline \multirow[b]{2}{*}{ Respostas } & \multicolumn{5}{|c|}{ REGIÃO ADMINISTRATIVA } & \multirow[b]{2}{*}{ Total } \\
\hline & Norte & Nordeste & Sudeste & Sul & $\begin{array}{c}\text { Centro- } \\
\text { Oeste }\end{array}$ & \\
\hline Não & $85 \%$ & $88 \%$ & $89 \%$ & $86 \%$ & $90 \%$ & $\begin{array}{l}6.488 \\
88 \%\end{array}$ \\
\hline Sim & $13 \%$ & $11 \%$ & $9 \%$ & $14 \%$ & $9 \%$ & $\begin{array}{r}737 \\
10 \%\end{array}$ \\
\hline Não respondeu & $2 \%$ & $1 \%$ & $2 \%$ & 0 & $2 \%$ & $\begin{array}{l}147 \\
2 \%\end{array}$ \\
\hline BASE & 1.157 & 1.988 & 1.334 & 1.597 & 1.297 & 7.373 \\
\hline
\end{tabular}

Do mesmo modo, não se observam diferenças na frequência de utilização dos serviços de saúde oferecidos ao estudante quanto à distribuição das respostas nas cinco regiões administrativas.

Tabela 10- - Distribuição das respostas conforme o curso em que o aluno está matriculado, em relação ao uso do programa de atendimento à saúde dos alunos.

\begin{tabular}{|l|c|c|c|c|}
\hline \multirow{2}{*}{ Respostas } & \multicolumn{2}{|c|}{ ÁREA DE ESTUDO } & \multirow{2}{*}{ Total } \\
\cline { 2 - 5 } & Biológicas/Saúde & Exatas & Humanas & \\
\hline Não & $85 \%$ & $90 \%$ & $89 \%$ & $\begin{array}{c}\mathbf{6 . 4 8 8} \\
\mathbf{8 8 \%}\end{array}$ \\
\hline Sim & & & & $\mathbf{7 3 7}$ \\
& $14 \%$ & $8 \%$ & $8 \%$ & $\mathbf{1 0 \%}$ \\
\hline Não respondeu & & & & $\mathbf{1 4 7}$ \\
& & $2 \%$ & $2 \%$ & $\mathbf{2 \%}$ \\
\hline BASE & & & & $\mathbf{7 . 3 7 3}$ \\
\hline
\end{tabular}


Entre os alunos matriculados nos cursos ligados à área biológica/saúde, $14 \%$ dizem frequentar o programa de atendimento à saúde discente. Esse número é maior do que o encontrado em cursos de outras áreas: $8 \%$ nos cursos de exatas e $8 \%$ nos cursos de ciências humanas.

\section{Informações recebidas sobre o uso de álcool e outras drogas e seu impacto na saúde, fornecidas pela IES nos últimos 12 meses.}

Em relação às informações recebidas na IES em que está matriculado sobre o uso de álcool e de outras drogas e seu impacto sobre a saúde, $71 \%$ dos estudantes assinalaram que nos últimos 12 meses não receberam informação sobre esse tema em suas IES, $23 \%$ declaram ter recebido informações e $6 \%$ não responderam à pergunta.

Tabela 11 - Distribuição das respostas por gênero, região administrativa e tipo de IES quanto a ter recebido informações sobre o uso de drogas e seu impacto na saúde nos últimos 12 meses.

\begin{tabular}{|c|c|c|c|c|c|c|c|c|c|c|}
\hline \multirow[b]{2}{*}{ Respostas } & \multicolumn{2}{|c|}{ GÊNERO } & \multicolumn{5}{|c|}{ REGIÃO ADMINISTRATIVA } & \multicolumn{2}{|c|}{ TIPO DE IES } & \multirow[b]{2}{*}{ Tota } \\
\hline & Masculino & Feminino & Norte & $\begin{array}{l}\text { Norde } \\
\text { ste }\end{array}$ & $\begin{array}{l}\text { Centro- } \\
\text { Oeste }\end{array}$ & Sudeste & Sul & Pública & Privada & \\
\hline Não & $67 \%$ & $75 \%$ & 71\% & $73 \%$ & $70 \%$ & $71 \%$ & $73 \%$ & $76 \%$ & $70 \%$ & $\begin{array}{l}9.025 \\
71 \%\end{array}$ \\
\hline Sim & $26 \%$ & $20 \%$ & $23 \%$ & $25 \%$ & $26 \%$ & $22 \%$ & $23 \%$ & $21 \%$ & $23 \%$ & $\begin{array}{l}2.924 \\
23 \%\end{array}$ \\
\hline $\begin{array}{l}\text { Não } \\
\text { Respondeu }\end{array}$ & $7 \%$ & $5 \%$ & $6 \%$ & $2 \%$ & $4 \%$ & $7 \%$ & $4 \%$ & $3 \%$ & $7 \%$ & $\begin{array}{l}763 \\
6 \%\end{array}$ \\
\hline Total & 5.682 & 6.995 & 2.305 & 3.200 & 2.199 & 2.566 & 2.441 & 6.206 & 6.505 & 12.711 \\
\hline
\end{tabular}

Em relação ao gênero, 26\% dos homens declaram ter recebido alguma informação sobre esse tema, enquanto entre as mulheres 20 respondem que receberam informação. Analisando os resultados por região administrativa e tipo de IES, observa-se que as porcentagens são semelhantes (tabela 11). 
Tabela12 - Frequência das respostas dos estudantes por área do curso quanto a ter recebido informações sobre o uso de drogas e seu impacto na saúde nos últimos 12 meses.

\begin{tabular}{|l|c|c|c|c|}
\hline \multirow{2}{*}{} & \multicolumn{3}{|c|}{ Área de estudo } & \multirow{2}{*}{ Total } \\
\cline { 2 - 5 } & Biológicaslsaúde & Exatas & Humanas & \\
\hline Não & $66 \%$ & $70 \%$ & $73 \%$ & $\mathbf{9 . 0 2 5}$ \\
& & & & $\mathbf{7 1 \%}$ \\
\hline Sim & $30 \%$ & $24 \%$ & $20 \%$ & $\mathbf{2 . 9 2 4}$ \\
& & & & $\mathbf{2 3 \%}$ \\
\hline Não respondeu & $4 \%$ & $6 \%$ & $7 \%$ & $\mathbf{7 6 3}$ \\
& & & & $\mathbf{6 \%}$ \\
\hline & $\mathbf{3 . 2 1 2}$ & $\mathbf{3 . 2 7 6}$ & $\mathbf{6 . 0 0 7}$ & $\mathbf{1 2 . 7 1 1}$ \\
\hline
\end{tabular}

Ainda em relação a esse questionamento, as respostas afirmativas observadas nos diferentes cursos mostram que 30\% dos alunos de ciências biológicas tiveram informações, frequência maior quando comparados às demais áreas do conhecimento e ao índice geral, 23\%. Entre os alunos de ciências humanas está a menor porcentagem, 20\% de respostas afirmativas (tabela 12).

Para os alunos que responderam terem recebido na sua IES informação sobre o uso de álcool e outras drogas e seu impacto sobre sua saúde nos últimos 12 meses, foi perguntado qual a metodologia empregada na divulgação dessas informações. Nesta questão o aluno poderia assinalar mais de uma opção. 
Tabela13 - Distribuição das respostas dos estudantes quanto metodologia empregada na divulgação de informações sobre o uso de drogas e seu impacto na saúde nos últimos 12 meses analisados área do curso e gênero. ( Mais de uma resposta possível) $\mathrm{N}=3150$

\begin{tabular}{|l|c|c|c|c|c|c|}
\hline \multirow{2}{*}{ Metodologia } & \multicolumn{2}{|c|}{ ÁREA DE ESTUDO } & \multicolumn{2}{c|}{ GÊNERO } & Total \\
\cline { 2 - 6 } & $\begin{array}{c}\text { Biológica } \\
\text { s }\end{array}$ & Exatas & Humanas & $\begin{array}{c}\text { Masculin } \\
0\end{array}$ & $\begin{array}{c}\text { Feminin } \\
0\end{array}$ & \\
\hline $\begin{array}{l}\text { Aulas, palestras, } \\
\text { reuniões ou } \\
\text { workshops }\end{array}$ & $60 \%$ & $55 \%$ & $47 \%$ & $48 \%$ & $55 \%$ & $\begin{array}{c}1.606 \\
51 \%\end{array}$ \\
\hline $\begin{array}{l}\text { Cartas, comunicados } \\
\text { ou panfletos }\end{array}$ & $24 \%$ & $26 \%$ & $25 \%$ & $30 \%$ & $21 \%$ & 787 \\
\hline $\begin{array}{l}\text { Pôsteres } \\
\text { informativos }\end{array}$ & $23 \%$ & $29 \%$ & $23 \%$ & $23 \%$ & $25 \%$ & 756 \\
\hline $\begin{array}{l}\text { Leitura nos jornais } \\
\text { dos estudantes }\end{array}$ & $23 \%$ & $11 \%$ & $21 \%$ & $18 \%$ & $21 \%$ & 630 \\
\hline $\begin{array}{l}\text { Curso especial sobre } \\
\text { álcool e drogas }\end{array}$ & $3 \%$ & $7 \%$ & $6 \%$ & $9 \%$ & $3 \%$ & 189 \\
\hline Não respondeu & $6 \%$ & $2 \%$ & $5 \%$ & $3 \%$ & $7 \%$ & 157 \\
\hline Total de alunos & 1.169 & $\mathbf{6 8 5}$ & 1.240 & 1.479 & 1.661 & 3.150 \\
\hline
\end{tabular}

As informações são oferecidas aos alunos com diferentes metodologias e instrumentos. As informações mais lembradas pelos alunos (51\%) foram as oferecidas em aulas, palestras, reuniões ou workshops, sendo que essa porcentagem é maior nas respostas dos alunos dos cursos da área de biologia/saúde. A frequência de respostas em relação às outras maneiras da IES divulgar informações sobre o tema pode ser observada na tabela 12. Apenas $6 \%$ dos alunos assinalam ter recebido informações pela participação em curso específico que tinha como tema álcool e outras drogas.

A distribuição das respostas dos alunos quanto à metodologia empregada para a divulgação de informações sobre o consumo de drogas e seu impacto na saúde oferecidas pelas IES, por região administrativa e tipo de IES, é apresentada na tabela 14. 
Tabela 14 - Distribuição das respostas por tipo de IES e região administrativa quanto a metodologia empregada na divulgação de informações sobre o uso de drogas, seu impacto na saúde nos últimos 12 meses (possibilidade de assinalar mais de uma resposta) $\mathrm{N}=3.150$

\begin{tabular}{|c|c|c|c|c|c|c|c|c|}
\hline \multirow{2}{*}{ Metodologia } & \multicolumn{2}{|c|}{ TIPO DE IES } & \multicolumn{5}{|c|}{ REGIÂO ADMINISTRATIVA } & \multirow[b]{2}{*}{ Total } \\
\hline & Pública & Privada & Norte & Nordeste & $\begin{array}{l}\text { Centro- } \\
\text { Oeste }\end{array}$ & Sudeste & Sul & \\
\hline $\begin{array}{l}\text { Aulas, palestras, } \\
\text { reuniões ou workshops }\end{array}$ & $47 \%$ & $53 \%$ & $49 \%$ & $53 \%$ & $58 \%$ & $51 \%$ & $44 \%$ & $51 \%$ \\
\hline $\begin{array}{l}\text { Cartas, comunicados } \\
\text { ou panfletos }\end{array}$ & $32 \%$ & $23 \%$ & $32 \%$ & $28 \%$ & $21 \%$ & $23 \%$ & $42 \%$ & $21 \%$ \\
\hline Pôsteres informativos & $39 \%$ & $20 \%$ & $31 \%$ & $35 \%$ & $24 \%$ & $19 \%$ & $53 \%$ & $24 \%$ \\
\hline $\begin{array}{l}\text { Artigos e informativos } \\
\text { nos jornais dos } \\
\text { estudantes }\end{array}$ & $24 \%$ & $18 \%$ & $18 \%$ & $28 \%$ & $17 \%$ & $17 \%$ & $29 \%$ & $17 \%$ \\
\hline $\begin{array}{l}\text { Curso especial sobre } \\
\text { álcool e drogas }\end{array}$ & $5 \%$ & $6 \%$ & $5 \%$ & $6 \%$ & $5 \%$ & $6 \%$ & $6 \%$ & $5 \%$ \\
\hline Não respondeu & $3 \%$ & $5 \%$ & $7 \%$ & $2 \%$ & $6 \%$ & $6 \%$ & 0 & $6 \%$ \\
\hline Total & 1.449 & 1.701 & 600 & 832 & 623 & 552 & 543 & 3.150 \\
\hline
\end{tabular}

\section{Ajuda na instituição para reduzir ou parar o consumo de álcool ou outras drogas}

A última questão que os estudantes deveriam responder era sobre a possibilidade de obter ajuda na instituição (conselho, professores ou outro adulto) para reduzir ou parar o consumo de álcool ou outras drogas, 40\% acreditam ser possível ou muito possível obter ajuda, 8\% acham não ser possível e $51 \%$ não sabem ou não responderam.

Tabela 15 - Distribuição das respostas quanto à possibilidade de encontrar ajuda na IES para reduzir ou parar o consumo de álcool ou outras drogas.

\begin{tabular}{|c|c|c|c|c|c|c|c|c|c|c|c|}
\hline & \multicolumn{2}{|c|}{ TIPO DE IES } & \multicolumn{5}{|c|}{ REGIÃO ADMINISTRATIVA } & \multicolumn{3}{|c|}{ ÁREA DE ESTUDO } & \multirow{2}{*}{ Total } \\
\hline & $\begin{array}{l}\text { Públic } \\
\text { a }\end{array}$ & Privada & Norte & Nordeste & Sudeste & Sul & $\begin{array}{l}\text { Centro- } \\
\text { Oeste }\end{array}$ & Biológicas & Exatas & $\begin{array}{l}\text { Huma } \\
\text { nas }\end{array}$ & \\
\hline $\begin{array}{l}\text { Muito } \\
\text { possível }\end{array}$ & $9 \%$ & $14 \%$ & $13 \%$ & $10 \%$ & $14 \%$ & $16 \%$ & $11 \%$ & $15 \%$ & $14 \%$ & $13 \%$ & $13 \%$ \\
\hline Possível & $31 \%$ & $26 \%$ & $29 \%$ & $30 \%$ & $26 \%$ & $33 \%$ & $33 \%$ & $32 \%$ & $26 \%$ & $26 \%$ & $27 \%$ \\
\hline $\begin{array}{l}\text { Não é } \\
\text { possível }\end{array}$ & $9 \%$ & $8 \%$ & $8 \%$ & $9 \%$ & $8 \%$ & $9 \%$ & $7 \%$ & $4 \%$ & $9 \%$ & $9 \%$ & $8 \%$ \\
\hline Não sei & $47 \%$ & $41 \%$ & $40 \%$ & $46 \%$ & $42 \%$ & $37 \%$ & $42 \%$ & $42 \%$ & $42 \%$ & $42 \%$ & $42 \%$ \\
\hline $\begin{array}{l}\text { Não } \\
\text { respondeu }\end{array}$ & $5 \%$ & $10 \% \$$ & $8 \%$ & $5 \%$ & $10 \%$ & $5 \%$ & $6 \%$ & $7 \%$ & $9 \%$ & $9 \%$ & $9 \%$ \\
\hline Total & 6.206 & 6.505 & 2.305 & 3.200 & 2.566 & 2.441 & 2.199 & 3.212 & 3.276 & 6.007 & 12.711 \\
\hline
\end{tabular}


Em relação a essa resposta, observa-se que, de um modo uniforme, $42 \%$ dos alunos respondem não saber se podem obter essa ajuda 37\% na região Sul e $46 \%$ na região Nordeste, a maior porcentagem Não aparecem diferenças em relação à área do curso. Em todas as áreas, $42 \%$ dos alunos não sabem se é possível encontrar essa ajuda.

Em relação ao gênero, $42 \%$ dos homens e $39 \%$ das mulheres acreditam ser possível ou muito possível encontrar ajuda na IES. Nos dois gêneros, 8\% responderam que não é possível encontrar ajuda. Responderam não saber se poderão encontrar ajuda $38 \%$ dos homens e $46 \%$ das mulheres, e não responderam a essa questão $11 \%$ dos homens e $7 \%$ das mulheres.

\subsection{Respostas das instituições ao questionário}

O segundo instrumento de coleta de dados foi um questionário semiestruturado (ANEXO D), que foi respondido por $82 \%$ das instituições (82 em 100) que aceitaram participar da pesquisa, enquanto $18 \%$ das instituições (18 em 100) não responderam, mesmo após múltiplas solicitações por contatos pessoais, via telefone e e-mails com os interlocutores designados pelas instituições.

Existência na IES de um programa/projeto de prevenção, orientação ou assistência ao estudante em relação ao consumo de álcool, tabaco ou outras drogas

Os dados abaixo relacionados têm como base da amostra as 82 (100\%) IES que responderam ao instrumento. A presença de projeto ou programa de prevenção, orientação ou assistência do uso de álcool, tabaco e outras drogas, direcionados ao corpo discente, foi relatada em $32,9 \%$ (27 em 100) das instituições; em 67,1\% (55 em 100) não existe projeto nesse tema. Quando essa questão foi respondida negativamente, houve a exclusão do questionário, uma vez que as demais questões dependiam da existência do projeto. 
Em relação à existência de um programa voltado ao discente e ao número de cursos, foi observado que a maioria das instituições nas quais existe um programa, 85,7\% (23 em 27) são instituições com mais de vinte cursos, 11,1\% (3 em 27) possuem entre 11 e 20 cursos e apenas 3,7\% (1 em 27) tem até 10 cursos.

Tabela 16 - Distribuição do número de cursos oferecidos pelas IES que responderam de modo afirmativo ao questionário quanto à existência de programas de prevenção, orientação ou assistência ao consumo de drogas pelos estudantes

\begin{tabular}{|l|c|c|c|c|c|}
\hline \multicolumn{2}{|c|}{} & \multicolumn{4}{|c|}{ Respostas SIM (27) } \\
\hline N & $\begin{array}{c}\text { No total das } \\
\text { IES }\end{array}$ & & Públicas & Privadas & $\begin{array}{c}\text { Com cursos } \\
\text { de saúde }\end{array}$ \\
\hline 1 A 10 & $21(21 \%)$ & $\begin{array}{c}\mathbf{1} \\
\mathbf{( 3 , 7 \% )}\end{array}$ & 0 & $\begin{array}{c}1 \\
(3,7 \%)\end{array}$ & $\begin{array}{c}1 \\
(3,7 \%)\end{array}$ \\
\hline 11 A 20 & $14(14 \%)$ & $\mathbf{3}$ & $\begin{array}{c}1 \\
(3,7 \%)\end{array}$ & $\begin{array}{c}2 \\
(7,4 \%)\end{array}$ & $\begin{array}{c}1 \\
(3,7 \%)\end{array}$ \\
\hline 21 A 50 & $37(37 \%)$ & $\mathbf{1 1}$ & 6 & 5 & 11 \\
& & $\mathbf{( 4 0 , 7 \% )}$ & $(22,2 \%)$ & $(18,5 \%)$ & $(40,7 \%)$ \\
\hline + 50 & $28(28 \%)$ & $\mathbf{1 2}$ & $\begin{array}{c}11 \\
(40,7 \%)\end{array}$ & $\begin{array}{c}1 \\
(3,7 \%)\end{array}$ & $\begin{array}{c}10 \\
(37 \%)\end{array}$ \\
\hline TOTAL & $100(100)$ & $\mathbf{2 7}$ & $\begin{array}{c}18 \\
(66,7 \%)\end{array}$ & $\begin{array}{c}9 \\
(33,3 \% \$)\end{array}$ & $\begin{array}{c}24 \\
(88,9 \%)\end{array}$ \\
\hline
\end{tabular}

As instituições públicas correspondem a 66,7\% (18 em 27) dos projetos, e as privadas a $33,3 \%$ (9 em 27). Cursos da área de saúde estão presentes em $88,9 \%$ (24 em 27) das IES com projeto. As frequências das respostas das IES por região administrativa e tipo de IES (pública ou privada) estão discriminadas na tabela 17. 
Tabela 17 - A distribuição dos programas existentes por região administrativa e tipo de IES de acordo com as respostas ao questionário.

\begin{tabular}{|c|c|c|c|c|}
\hline Região, Regime & Sim & Não & $\begin{array}{c}\text { Não } \\
\text { Responde } \\
\mathbf{u}\end{array}$ & Total de IES \\
\hline Norte & $\mathbf{5}$ & $\mathbf{1 3}$ & $\mathbf{6}$ & $\mathbf{2 4}$ \\
\hline Privadas & 3 & 6 & 4 & 13 \\
\hline Públicas & 2 & 7 & 2 & 11 \\
\hline Nordeste & $\mathbf{8}$ & $\mathbf{2 0}$ & $\mathbf{4}$ & $\mathbf{3 2}$ \\
\hline Privadas & 0 & 14 & 3 & 17 \\
\hline Públicas & 8 & 6 & 1 & 15 \\
\hline Centro Oeste & $\mathbf{2}$ & $\mathbf{9}$ & $\mathbf{2}$ & $\mathbf{1 3}$ \\
\hline Privadas & 1 & 4 & 1 & 6 \\
\hline Públicas & 1 & 5 & 1 & 7 \\
\hline Sudeste & $\mathbf{7}$ & $\mathbf{1 0}$ & $\mathbf{3}$ & $\mathbf{2 0}$ \\
\hline Privadas & 4 & 5 & 2 & 11 \\
\hline Públicas & 3 & 5 & 1 & 9 \\
\hline Sul & $\mathbf{5}$ & $\mathbf{3}$ & $\mathbf{3}$ & $\mathbf{1 1}$ \\
\hline & 1 & 1 & 3 & 5 \\
\hline Privadas & 4 & 2 & 0 & 6 \\
\hline Públicas & $\mathbf{9}$ & $\mathbf{3 0}$ & $\mathbf{1 3}$ & $\mathbf{5 2}$ \\
\hline Total de Privadas & $\mathbf{1 8}$ & $\mathbf{2 5}$ & $\mathbf{5}$ & $\mathbf{4 8}$ \\
\hline Total geral & $\mathbf{2 7}$ & $\mathbf{5 5}$ & $\mathbf{1 8}$ & $\mathbf{1 0 0}$ \\
\hline
\end{tabular}

Inclusão no Projeto Pedagógico Institucional ou no Plano de Desenvolvimento Institucional

Em relação à inclusão do programa (de prevenção, orientação ou assistência) no Plano de Desenvolvimento Institucional (PDI) ou Projeto Pedagógico Institucional (PPI), 63\% (17 de 27) responderam sim. Em 22,2\% (6 de 27) das IES o projeto não faz parte de nenhum dos dois documentos e $14,8 \%$ (4 de 27) não responderam a essa questão. É importante assinalar que a presença do projeto em cada um dos documentos foi feita em questões diferentes e foram respondidas da mesma maneira, ou seja, em todas as IES nas quais o projeto está incluído no PPI, também foi assinalado que ele faz parte do PDI. Em 63\% (17 em 27) ele se delineia como um projeto de extensão (respostas não se excluem). 
Como resposta ao tipo de ação que o programa se propõe realizar, as instituições informaram que: o foco é a prevenção (81,5\% - 20 em 27 IES ); o foco é a orientação ao estudante $(44,4 \%-12$ em 27$)$; o foco é a assistência $(48,1 \%$ 13 em 27). Esses dados podem ser observados na Figura 1:

Figura 1 - Ações planejadas como enfrentamento ao consumo de drogas segundo o objetivo das IES

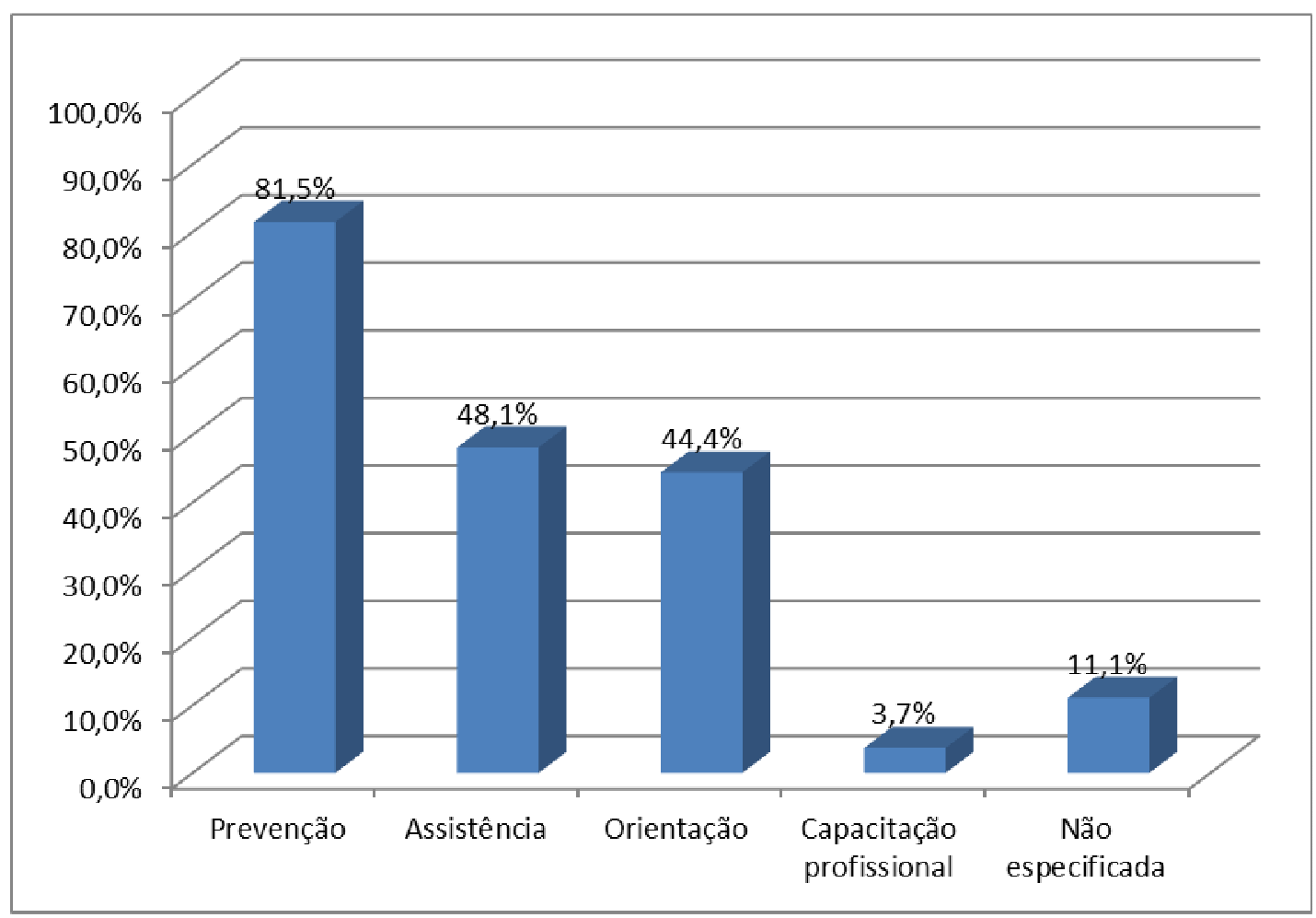

Muitas IES possuem mais de uma frente de atuação, distribuídas do seguinte modo: $33,3 \%$ delas ( 9 em 27) atuam nas 3 áreas: prevenção, orientação e assistência; 25,9\% (7 em 27 ), só na prevenção; 11,1\% (3 em 27) na orientação e na prevenção; 11,1\% (3 em 27) na prevenção e na assistência; 3,7\% (uma em 27) atua só na assistência e 3,7\% (uma em 27) apenas na capacitação profissional. Em 3 instituições (11,1\%), o tipo de ação oferecido não foi explicitado (Figura 2). 
Figura 2 - Intersecção entre os diferentes tipos de ações planejadas nos programas: prevenção, orientação e/ou assistência.

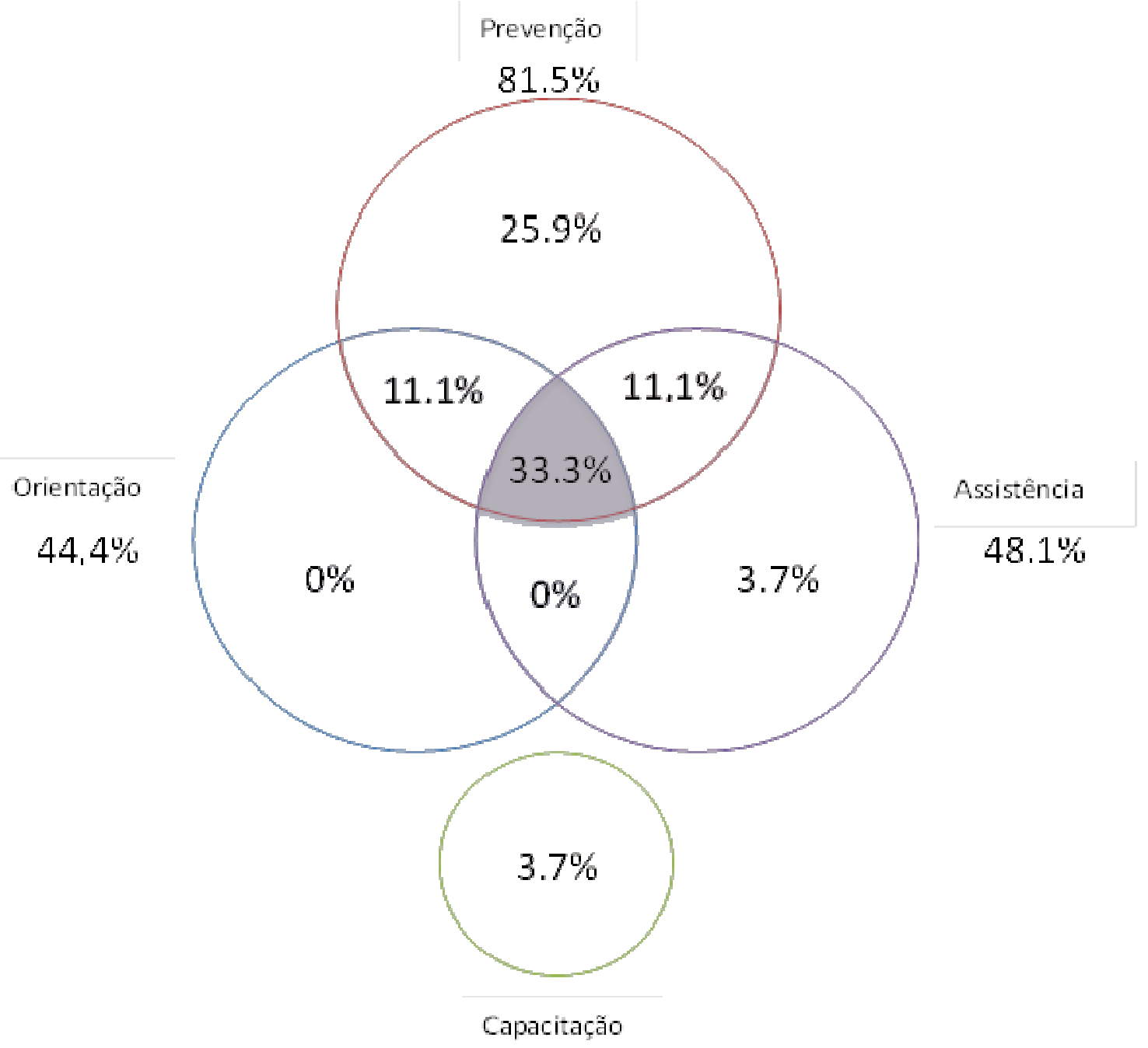

\section{Público-alvo, Acesso e Divulgação}

Entre os programas de prevenção/orientação/assistência relacionados ao uso de drogas para o corpo discente, 14,8\% (4 em 27) são voltados apenas ao atendimento do aluno; em 51,9\% (14 em 27) das instituições, toda a comunidade acadêmica é atendida, e em 33,3\% (9 em 27) das instituições o programa é voltado para o público em geral, e os estudantes podem ser atendidos. 
O acesso do aluno ao programa ocorre de diferentes maneiras: por encaminhamento de órgãos institucionais em 29,6\% (8 em 27) das IES; através de busca espontânea em 25,9\% (7 em 27); por referência interna ou externa em $22,2 \%$ ( 6 em 27); através de palestras em 11,1\% ( 3 em 27); faz parte dos programas curriculares em $7,4 \%$ (2 em 27); e os alunos participam como bolsistas em 3, 7\% (1 em 27).

Os programas existentes são divulgados nas instituições de diferentes maneiras por $92,6 \%$ (25 em 27) das IES, e 7,4\% (2 em 27) das instituições acreditam não haver necessidade de divulgação, pois os programas já são bem conhecidos.

Tabela 18: Frequência das estratégias de divulgação interna dos programas de prevenção orientação ou assistência presentes nas IES

\begin{tabular}{|l|l|}
\hline Estratégias de divulgação interna & Frequência \\
\hline Site & $9(33,3 \%)$ \\
\hline Órgãos de divulgação interna & $8(29,6 \%)$ \\
\hline Folders e cartazes & $3(11,1 \%)$ \\
\hline Cinema, debates e seminários & $2(7,4 \%)$ \\
\hline Sala de aula & $1(3,7 \%)$ \\
\hline Manual do aluno & $1(3,7 \%)$ \\
\hline Publicações & $1(3,7 \%)$ \\
\hline Total parcial & $25(92,6 \%)$ \\
\hline Não há necessidade de divulgação & $2(7,4 \%)$ \\
\hline & $27(100 \%)$ \\
\hline
\end{tabular}

Entre as diferentes estratégias de divulgação interna dos projetos, as mais citadas foram: site institucional, 33,3\% (9 em 27), e órgãos de divulgação interna não especificados $29,6 \%$ (8 em 27). Outros meios referidos estão discriminados na tabela 18. 
Como outros públicos (comunidade externa) podem participar do programa/projeto de algumas instituições, foi perguntado como é a divulgação fora da IES. O programa não é divulgado fora da instituição em $51,9 \%$ das IES (14 em 27); $44,4 \%$ o divulgam (12 em 27) e 3,7\% (1 em 27) não responderam a esse questionamento. Quando existe, essa divulgação ocorre de diferentes modos, que incluem: site da IES, cursos e palestras, rádio e televisão, material impresso, visitas, parcerias e departamento de recursos humanos.

\section{Participação do Aluno}

O acesso do estudante ao programa pode ocorrer de diferentes maneiras: em 29,6\% (8 em 27) das IES, por encaminhamento de órgãos institucionais; em $25,9 \%$ (7 de 27), através de busca espontânea; em 22, 2\% (6 de 27), por referência interna ou externa; em 11,1\% (3 de 27), através de palestras; em 7,4\% (2 de 27), faz parte dos programas curriculares; e em 3, 7\% (1 de 27), o aluno participa como bolsista e sua atividade não foi mencionada.

\section{Responsável pelo Projeto}

Dentro de cada IES a responsabilidade pelo projeto é muito variável: um grupo específico foi nomeado em 40,7\% (11 em 27) das instituições; o departamento de extensão é responsável por $25,9 \%$ dos projetos; o núcleo pedagógico por $11,1 \%$; a secretaria ou a diretoria de assuntos estudantis por $7,4 \%$; e uma IES não informou (tabela 19). 
Tabela 19 - Distribuição dos responsáveis pelo projeto nas instituições

\begin{tabular}{|l|l|}
\hline Responsável pelo programa & Número de IES \\
\hline Grupo específico & $11(40,7 \%)$ \\
\hline Extensão & $7(25,9 \%)$ \\
\hline Núcleo pedagógico & $3(11,1 \%)$ \\
\hline Um profissional & $3(11,1 \%)$ \\
\hline Secretaria/diretoria de assuntos estudantis & $2(7,4 \%)$ \\
\hline Não informou & $1(3,7 \%)$ \\
\hline Total de IES & 27 \\
\hline
\end{tabular}

\subsection{Pesquisa no site}

Ao mesmo tempo em que os representantes respondiam ao questionário, outro instrumento de coleta de dados era utilizado: a busca de informação nos portais/sites das instituições.

O instrumento de coleta de dados "busca na internet através do sites/portais" de cada uma das 100 instituições que participaram teve como resultado o encontro de 20 IES que possuíam alguma modalidade de programa/projeto referente à prevenção, à orientação ou à assistência aos discentes em relação ao uso de álcool, tabaco e outras drogas. Das sete instituições nas quais a existência de projeto não foi encontrada no site e responderam de modo afirmativo no questionário, nenhuma enviou o projeto.

Fica claro o envolvimento das IES em relação ao problema do uso de drogas pelo corpo discente, uma vez que observamos que 53 das IES (53\% de 100 ) apresenta em seu site oficial atividades curriculares, eventos pontuais ou campanhas que abordam o tema, embora nem sempre se caracterize a existência de um programa. 


\subsection{Site e questionário}

Associando os dados obtidos através dos questionários e a busca nos sites, foi observada a presença de projetos em 20 instituições nos dois instrumentos e resultados diferentes (resposta sim no formulário e não obteve confirmação do programa no site) em sete IES. É importante relatar que em uma instituição foi identificada a existência de um programa no site, mas como ela não respondeu ao formulário, não foi incluída na análise de dados, sete instituições que responderam sim quanto à existência do projeto no questionário, quando esse projeto foi solicitado para análise, quatro IES declaram não ter o programa ainda escrito.

Comparando as informações obtidas nas questões abertas do questionário com os dados obtidos através da análise dos sites, pode-se ainda observar que Núcleos/Grupos de apoio pedagógico ou psicopedagógico ao discente estão presentes em 66,7\% (18 em 27) das IES que declaram possuir programa relacionado ao uso de drogas, 29,6\% (8 em 27) não forneceram essa informação e $3,7 \%$ (1 em 27) não o possuem. Em relação à frequência, do total de escolas que compunham a amostra - 100 IES -, apenas 31\% (31 em 100) possuem esse núcleo (dados obtidos na análise dos portais das IES).

\subsection{Análise dos projetos}

Quando são observados os dados obtidos nas respostas ao questionário e no site por região geográfica, observamos:

- Na região Norte, $22,8 \%$ (5 em 27) das escolas têm projeto, sendo duas públicas e três privadas. Quanto ao público a que se destina o projeto, dois são específicos para o corpo discente, dois se destinam à comunidade acadêmica e um à comunidade em geral. Dos dois projetos enviados pelas IES para análise qualitativa, um é de escola pública e outro de escola privada.

- Na região Nordeste, oito escolas $(25 \%)$, todas públicas, responderam sim à existência de um projeto. Duas escolas não têm o projeto escrito (uma 
estava em fase de construção). Em relação aos oito projetos, observa-se que quatro projetos se dirigem à comunidade em geral, dois para a comunidade acadêmica e dois são específicos para o corpo discente. Quatro projetos foram enviados pelas IES para análise.

- No Centro-Oeste, duas escolas $(13,4 \%$ ) (uma pública e uma privada) têm projetos. Uma refere ainda que o projeto está em construção. Ambos são projetos não específicos para alunos, mas dirigidos para a comunidade em geral. Dois projetos desta região foram enviados pelas IES para análise.

- Na região Sudeste, é observada a presença de projeto em $35 \%$ das instituições (7 em 20), três públicas e quatro privadas. Quanto ao público a que se destina 0 projeto, observamos que cinco são voltados para a comunidade acadêmica e dois se destinam à comunidade em geral. Foram enviados pelas IES cinco projetos para análise, três de escolas públicas e dois de privadas.

- Na região Sul, 54,5\% (6 em 11) das escolas (quatro públicas e duas privadas) responderam sim em relação à existência de um projeto. Quanto ao público a que se destina, observamos que quatro projetos se destinam à comunidade acadêmica, um é específico para o corpo discente e um à comunidade em geral. Foram enviados pelas IES para análise cinco projetos, três de escolas públicas e dois de escolas privadas.

Tabela 20 - Distribuição dos projetos analisados e total de projetos por região administrativa.

\begin{tabular}{|l|c|c|}
\hline & $\begin{array}{c}\text { Projetos obtidos para } \\
\text { análise }\end{array}$ & $\begin{array}{c}\text { Total de projetos } \\
\text { existentes }\end{array}$ \\
\hline Norte & 2 & 5 \\
\hline Nordeste & 4 & 8 \\
\hline Centro Oeste & 2 & 2 \\
\hline Sudeste & 5 & 7 \\
\hline Sul & 5 & 6 \\
\hline TOTAL & $18(66,7 \%)$ & 27 \\
\hline
\end{tabular}


Foram, então, analisados 18 projetos de prevenção, orientação ou assistência ao discente em relação ao uso de álcool, tabaco e outras drogas. Esses projetos foram enviados pelas IES ou constavam no site. Entre as 27 IES que afirmaram possuir um projeto, cinco não foram obtidos (não foram enviados $\mathrm{e}$ não foram divulgados no portal) e quatro instituições (14,8\% de 27$)$ declararam ainda não ter o projeto escrito.

É importante esclarecer que os projetos foram solicitados para todas as IES que responderam afirmativamente sobre a existência de um projeto de prevenção, orientação ou assistência voltado ao corpo discente em relação ao consumo de álcool, tabaco e outras drogas. Todos os projetos enviados foram analisados (18 projetos).

$\mathrm{Na}$ fase inicial de observação dos documentos (pré-análise) foram identificadas seis unidades de análise relevantes para o conhecimento dos projetos: data de início do programa, inclusão do projeto no PPI/PPD, público-alvo, objetivos, ações (táticas e estratégias planejadas) e avaliação. Uma síntese é descrita como complemento após cada projeto.

\section{Projeto1}

Início: mais de 20 anos

Tema: Pesquisas em dependência química e envolvimento com drogas

Projeto incluído no PDI/PPI

Público-alvo: comunidade externa, mais focada em adolescentes

Objetivos (duas linhas de pesquisa):

- Contribuir com a evolução da abordagem científica das questões referentes à dependência química e envolvimento com drogas

- Construir metodologias de promoção à saúde 
Ações (estratégias e táticas):

- Investigação em relação à drogadição, sistemas de dependência e codependência com foco na adolescência e na família

- Construção de intervenções sistêmicas na prevenção e no tratamento das dependências químicas

- Estudo sob o ponto de vista epidemiológico, clínico e etnográfico

Metodologias de promoção à saúde com a formação de um corpo teóricoconceitual da intervenção clínica

- Formação de multiplicadores

Avaliação: Não especificada

Observações: Apesar de o tema (drogas) ser o foco, o estudante da IES não participa diretamente do projeto, que é voltado para a pesquisa e pretende construir uma base teórico-metodológica para intervenções, não havendo intervenções como ações previstas, mas o estudo delas. Portanto, não apresenta ações de prevenção, orientação ou acompanhamento dos alunos da IES. O projeto incluído no PDI mostra uma preocupação da IES com o tema drogas.

\section{Projeto 2}

Início: não especificado

Tema: Formação de multiplicadores, prevenção e educação

Projeto incluído no PDI/PPI

Público-alvo: comunidade externa e pessoas que vivem em situação de vulnerabilidade social

Objetivos:

- Capacitar a comunidade em ações junto a segmentos sociais em situação de vulnerabilidade

- Prestar assessoria a entidades governamentais ou não governamentais 
Ações (estratégias e táticas):

- Capacitação e assessoria a acadêmicos, profissionais e entidades governamentais e da comunidade

- Cursos de extensão. Cursos teóricos de prevenção e educação em relação ao uso abusivo de drogas

- Elaboração de pesquisas

- Palestras congressos, espaços de conversação e troca de experiências

- Estágio curricular

- Sessões de cinema com debates

Avaliação: Uso de indicadores e trabalhos de conclusão de curso (alunos).

Observações: O estudante participa através de estágios curriculares obrigatórios ou não obrigatórios, não é o foco das ações de prevenção. Uma indicação da preocupação com o tema é ele estar presente no PDI da instituição, apesar de não existirem ações de prevenção, orientação ou assistência tendo como foco os estudantes.

\section{Projeto 3}

Início: 1985

Tema: Estudos e terapia do abuso de drogas

Projeto não incluído no PDI/PPI

Público-alvo: comunidade externa

Objetivos:

- Acolher e oferecer tratamento psicoterápico a toda a comunidade

- Fornecer informações sobre o tema 
Ações (estratégias e táticas):

- Inclui atividades informativas, de acompanhamento e assistência

- Os alunos do curso de graduação de medicina têm um seminário de 16 horas

- Na prevenção, as estratégias usadas são palestras e recursos complementares, como música, teatro, fotografia e cerâmica

- Na orientação atende ao usuário e à família

- Assistência (sem hospitalização), com o programa de redução de riscos e consultório de rua

- No ensino são oferecidos cursos de especialização

- Atua também na área de pesquisa

- Núcleo editorial

Avaliação: Não especificada

Observações: É um projeto abrangente, voltado inicialmente para a comunidade em geral (projeto de extensão) e não como uma atividade específica para o atendimento acadêmico, mas os alunos estão incluídos nas ações de prevenção, orientação e assistência. Mesmo não fazendo parte do Plano de Desenvolvimento Institucional, ou sem compor o Projeto Pedagógico Institucional, acolhe e assiste os estudantes de forma abrangente.

\section{Projeto 4}

Início: não especificado

Tema: Estudos sobre drogas

Projeto não incluído no PDI/PPI

Público-alvo: comunidade interna e externa, com foco em escolas públicas

Objetivos:

- Fornecer subsídios para a construção de politicas sobre drogas no âmbito universitário e na sociedade 
- Atuar na prevenção ao uso de drogas, promover inclusão social e redução de danos

Ações (estratégias e táticas):

- Atuar no crescimento e no desenvolvimento pessoal, através de simpósios, oficinas públicas seminários

- Educação sobre drogas

- Promover um levantamento na IES sobre o comportamento dos estudantes de graduação frente ao uso de drogas psicotrópicas

- Publicação de livro com os resultados do projeto

Avaliação: Não especificada

Observações: Apesar de ser um projeto orientado para comunidade externa, um passo na aproximação das atividades com os estudantes da IES é a pesquisa, que se propõe mapear o comportamento dos estudantes e que poderá subsidiar ações no sentido de prevenção. O foco do projeto é a pesquisa e a prevenção.

\section{Projeto 5}

Início: 2005

Tema: Educação preventiva ao uso de drogas e formação permanente de pessoal para educação (multiplicadores)

Projeto incluído no PDI/PPI

Público-alvo: comunidade acadêmica e escolas públicas (comunidade externa) $\mathrm{O}$ aluno participa como multiplicador na educação preventiva

Objetivos:

- Consolidar o grupo de trabalho

- Sensibilizar, informar e capacitar multiplicadores em educação preventiva ao uso de drogas e grupos de apoio e de pesquisa 
- Contribuir para a formação de rede de escolas em todos os níveis de ensino

Ações (estratégias e táticas): em parceria com outras instituições

- Diagnóstico sobre a disseminação do uso de drogas lícitas e ilícitas na comunidade acadêmica (alunos e professores)

- Revisão e implementação de componentes curriculares que contemplem ações participativas e de educação preventiva ao uso de drogas

- Capacitação de multiplicadores para educação preventiva

- Formação de grupos de apoio para educadores, pais e alunos envolvidos no programa

- Elaboração de material educativo sobre o tema

- Realização de seminários sobre prevenção

- Elaboração de projetos de pesquisa

Avaliação: Sistemática, com o uso de critérios empíricos e científicos. Os indicadores serão construídos.

Observações: Trata-se de um projeto amplo do qual participa, além da IES, a rede pública de ensino da cidade e outras instituições envolvidas com a temática. Cinco projetos específicos fazem parte do programa, voltados para a área de educação e prevenção ao uso de drogas, elaboração de material didático, grupos de apoio e pesquisa. Uma mudança nos componentes curriculares faz parte do projeto. Tem como preocupação não apenas fornecer conhecimento, mas formar multiplicadores. O envolvimento da comunidade é no sentido de formar multiplicadores (profissionais da educação) e participação em eventos, além de realização de pesquisa para diagnóstico da disseminação do uso de drogas no campus. Os alunos também participam dos eventos, como multiplicadores, de grupos de apoio e pesquisa. 


\section{Projeto 6}

Início: 2000

Tema: Prevenção e apoio ao tratamento de alcoolismo e prevenção ao tabagismo em prol de melhor qualidade de vida.

Projeto incluído no PDI/PPI

Público-alvo: comunidade acadêmica e, indiretamente, familiares

Objetivos:

- Sensibilizar a comunidade

- Desenvolver ações de caráter social e preventivo, bem como apoio ao tratamento

- Promover a reintegração

- Orientar e atender os familiares

- Reduzir os custos institucionais causados pela doença e desenvolver política de melhoria da qualidade de vida através de ações de combate ao tabagismo.

Ações (estratégias e táticas):

- Encaminhamento, acompanhamento e avaliação;

- Acompanhamento médico, nutricional, educacional e físico; assistência social; prevenção, orientação e acompanhamento

- Realização de seminários, campanhas educativas, reuniões e contatos individuais

- Sensibilização e envolvimento de chefias, coordenadores e presidentes do centro acadêmico

- Instrumentos: filmes, cartazes

- Confecção de manuais, portarias e fichas de acompanhamento

- Campanhas

- Oferta de tratamento

Avaliação: Contínua e sistematizada, com indicadores estabelecidos. Adesão aos programas, envolvimento da comunidade universitária, avaliação com equipes técnicas multidisciplinares. 
Observações: São dois projetos que têm como foco o combate ao uso de tabaco e álcool no campus, voltados diretamente para a comunidade universitária, visando a prevenção, a orientação e a assistência. Tem como uma de suas preocupações a integração do paciente. Não envolve a comunidade extra ou externa à universidade. Avaliação prevista no processo. Presente no PDI e no PPP, o que mostra uma preocupação importante da instituição.

\section{Projeto 7}

Início: 2000

Tema: Prevenção ao uso de drogas

Projeto incluído no PDI/PPI

Público-alvo: alunos e familiares

Objetivos:

- Prevenir o consumo de drogas no campus

- Capacitar alunos bolsistas para conscientizar e prevenir em relação ao uso de drogas

Ações (estratégias e táticas):

- Estratégias de prevenção: atividades de integração, dinâmicas de relaxamento e laborativas, acompanhamento e visita domiciliar

- Orientação psicopedagógica

- Tratamento: psicoterapia individual, grupo de terapia, terapia de casal, terapia interfamiliar, interconsulta e atendimento psiquiátrico 
Avaliação: Não especificada.

Observações: Projeto elaborado para a comunidade estudantil e que se estende aos familiares com ações de prevenção, orientação e assistência ao estudante. A IES tem ainda um projeto de extensão que capacita o estudante de graduação como multiplicador na identificação, conscientização e prevenção do problema do uso de drogas. O estudante também pode participar de pesquisas para identificar o uso de drogas em colégios da região e de ações de prevenção na comunidade externa.

\section{Projeto 8}

Início: Não especificado

Tema: Apoio psicopedagógico ao estudante. Não é um programa específico sobre o tema estudado

Projeto incluído no PDI/PPI

Público-alvo: alunos, através de busca espontânea ou encaminhamento

Objetivos:

- Favorecer o desenvolvimento psicossocial discente através de ações de orientação e acompanhamento psicopedagógico

- Realizar campanhas de prevenção. Não é um programa específico

Ações (estratégias e táticas):

- Prevenção, campanhas e eventos

- Orientação e assistência (busca espontânea e encaminhamentos)

- Atendimento individual por demanda

- Atendimento psicopedagógico

- Intervenção individual e grupal

- Orientação e

- Encaminhamento 
Avaliação: Não especificada

Observações: Não é um programa específico, mas o núcleo promove eventos nos quais o tema pode ser incluído e atende os alunos que procuram o grupo, quer espontaneamente, quer encaminhados por professores, por problemas de aprendizado, saúde ou social.

\section{Projeto 9}

Início: 2000

Tema: Programa institucional de redução do uso indevido de drogas

Projeto incluído no PDI/PPI

Público-alvo: comunidade acadêmica.

Objetivos:

- Prevenir o uso indevido de drogas

- Conscientizar e sensibilizar a comunidade acadêmica no que diz respeito ao uso indevido de drogas e

- Realizar pesquisas

Ações (estratégias e táticas):

- Prevenção através de palestras, oficinas, comentários de filmes, mesas redondas

- Orientação (busca espontânea e encaminhamentos)

- Estratégias: produção de material didático

- Atendimentos individuais e em grupo, acompanhamento familiar

- Orientações e acompanhamentos

- Avaliação médica

- Participação em pesquisas 
Avaliação: Não especificada

Observações: Alunos são atendidos e também são multiplicadores. A instituição tem, ainda, um programa de extensão desenvolvido em escolas de ensino médio e fundamental com foco na prevenção e no tratamento.

\section{Projeto 10}

Início: 1998

Tema: Prevenção e reabilitação do alcoolismo e outras

Projeto incluído no PDI/PPI

Público-alvo: comunidade externa, alunos podem frequentar (alunos como usuário e formação profissional)

Objetivos:

- Tratar dos problemas relacionados ao álcool e outras drogas em nível de atenção primária e secundária e reabilitação

- Formular estratégias de prevenção para a comunidade

Ações (estratégias e táticas):

- Prevenção: ciclo de palestras

- Atendimento inicial: triagem - entrevista inicial, orientação e encaminhamento; avaliação geral - história clínica (pregressa, atual e de ingestão), exames físicos e laboratoriais, anamnese, exame físico e exames laboratoriais

Assistência: ambulatório de atendimento multidisciplinar, atendimento psicológico (individual e grupo), atendimento/orientação de família

- Tratamento, trabalho terapêutico realizado com ênfase numa abordagem biopsicossocial multidisciplinar para cada indivíduo, voltada para os problemas relacionados ao uso, abuso e dependência do álcool e outras drogas, dentro de uma visão sistêmica

- Grupo de reflexão de familiares e grupo de reflexão de usuários 
- Ensino - disciplinas na graduação, cursos de extensão e atualização, capacitação de grupos profissionais específicos

- Pesquisa produzindo dissertações, teses e artigos científicos

Avaliação: Não especificada

Observações: $O$ projeto atende o aluno, embora não desenhado exclusivamente para esse público. Projeto abrangente que atende à prevenção, à orientação e à assistência ao aluno frente à problemática do uso de drogas nas IES.

\section{Projeto 11}

Início: 1983

Tema: Assistência psicológica e prevenção, orientação e acompanhamento.

Projeto incluído no PDI/PPI

Público-alvo: alunos

Objetivos:

- Prestar assistência psicológica aos alunos de forma geral e

- Oferecer prevenção e acolhimento ao discente

Ações (estratégias e táticas):

- Prevenção: distribuição de boletins informativos, atualização sobre os recursos da comunidade para atendimento de dependentes químicos

- Orientação (profissional especializado) e esclarecimento de dúvidas, atendimento - Assistência: atendimento (demanda espontânea) para acolhimento e sensibilização, encaminhamento para tratamento dentro e fora da instituição, acompanhamento e atendimento a familiares

Avaliação: Não especificada 
Observações: O projeto enviado prevê ações de prevenção, orientação e assistência aos alunos, sem envolver outras populações. Foi informada, via e-mail, a existência de outros programas em unidades isoladas, sob a responsabilidade de diferentes cursos, bem como de núcleos pedagógicos de faculdades da IES. Um projeto abrangente para toda a IES está sendo formulado.

\section{Projeto 12}

Início: 1997

Tema: Prevenção ao uso de álcool e drogas

Projeto incluído no PDI/PPI

Público-alvo: alunos e funcionários

Objetivos:

- Compreender a extensão do problema

- Desenvolver habilidades para identificar, avaliar e fazer uma terapia breve Prevenir o consumo de drogas.

Ações (estratégias e táticas):

- Treinamento de equipes para dar atendimento aos usuários ou dependentes

- Criação de material informativo para os diferentes campi

- Realização de um programa específico de prevenção

- Campanhas de prevenção e programas educativos

- Discussão de políticas (normatização) do uso de álcool e drogas

- Estudo para implantação de um centro de referência

Avaliação: Não especificada

Observações: Projeto orientado para a atenção ao discente a partir de uma pesquisa de diagnóstico do problema cuja "principal conclusão foi que seria importante iniciar um programa de prevenção no primeiro ano de todas as 
faculdades, tanto para o uso de álcool e drogas como de gravidezes indesejadas e doenças sexualmente transmissíveis." Orientado por esse trabalho , foi elaborado um projeto voltado aos alunos, baseado no pressuposto da redução de danos. 0 programa faz também capacitação de equipes na região através de cursos para profissionais.

\section{Projeto 13}

Início: 1998

Tema: Assistência à saúde mental do estudante

Projeto incluído no PDI/PPI

Público-alvo: Inicialmente, estudantes, mas se ampliou atendendo a toda a comunidade acadêmica.

Objetivos:

- Prestar atendimento psicológico e psiquiátrico ao aluno

- Promover saúde individual, institucional e organizacional

Ações (estratégias e táticas):

- Prevenção, detecção precoce e tratamento ambulatorial do aluno que o busca espontaneamente ou é orientado a fazê-lo

- Atendimento de urgência, quando necessário. Terapia breve. $O$ atendimento ao aluno inclui o enfrentamento do problema

- Consultas médicas, no início do curso e busca espontânea

- Acompanhamento do problema do aluno

- Pesquisa

Avaliação: Presença de banco de dados e escalas de avaliação específicas.

Observações: $O$ projeto se iniciou com a finalidade de oferecer atendimento psicológico e psiquiátrico ao aluno e caminhou para um programa mais 
abrangente, em que se oferece um atendimento à saúde do discente como um todo sem deixar de ter o enfoque para a saúde mental.

\section{Projeto 14}

Início: 1996

Tema: Qualidade de vida, programa de extensão com ações gerais, que incluem a prevenção-educação em relação ao uso indevido de drogas tendo os alunos como multiplicadores, atuando na comunidade

Projeto incluído no PDI/PPI

Público-alvo: Comunidade em geral, alunos como multiplicadores

Objetivos:

- Visa a formação do indivíduo enquanto ser humano e social e a formação do cidadão, do profissional e do profissional cidadão.

Ações (estratégias e táticas):

O projeto é amplo e só estão aqui citadas as ações que envolvem a temática.

- Informativos e guias de qualidade de vida

- Capacitação de multiplicadores com palestras para o público interno e externo

- Eventos, campanhas e cursos

- Atendimento, aconselhamento e encaminhamento

Avaliação: Não especificada.

Observações: É um projeto de extensão preocupado com a formação geral do profissional e do cidadão. O aluno participa ativamente como multiplicador e, em datas determinadas, ações de prevenção são executadas. A qualidade de vida, de forma ampla, é objeto deste projeto, sendo confeccionados informativos e guias oferecidos à comunidade interna e externa da IES, envolvendo, assim, a escola e seu entorno. 


\section{Projeto 15}

Início: Não especificado

Tema: Atendimento psicopedagógico

Projeto incluído no PDI/PPI

Público-alvo: estudantes

Objetivos:

- Proporcionar atendimento psicopedagógico aos alunos que apresentam indicadores de dificuldades de aprendizagem e de integração social decorrentes de: problemas educacionais e psicológicos e transtornos mentais; dependência química, deficiência ou necessidades especiais.

Ações (estratégias e táticas):

- Acolhimento a estudantes que apresentam dificuldades na vida acadêmica. Identificação das necessidades

- Orientação e encaminhamento. Para consecução desta ação, serão utilizados recursos tanto da comunidade acadêmica como da externa

- Acompanhamento com vistas à qualidade da vida acadêmica

- Serviços de saúde, atendimento psicológico, fisioterapia, prevenção e atenção ao uso de drogas

Avaliação: Não especificada

Observações: Um programa que acompanha o aluno e que não tem como foco a temática do uso de drogas pelo corpo discente. A IES possui um serviço de saúde e pedagógico que, entre outros atendimentos, tem um programa de assistência e tratamento aos dependentes químicos.

\section{Projeto 16}

Início: 2007 
Tema: Qualidade de vida, prevenção sobre o uso de tabaco e álcool

Projeto incluído no PDI/PPI

Público-alvo: comunidade acadêmica

Objetivos:

- Prevenir o uso e promover saúde

- Promover ambiente livre do tabaco

- Alertar para os efeitos nocivos do álcool

Ações (estratégias e táticas):

- Campanhas de prevenção e promoção

- Ações a médio e longo prazo

- Envio de e-mails

- Trabalho junto aos diretórios e centros acadêmicos

- Divulgação e certificação de ambiente livre de tabaco

- Ações culturais: música, teatro, pintura do chão com desenhos, debates

- Placas educativas no campus, trabalho junto aos calouros ("portas de entrada")

Avaliação: Em toda a instituição para reajustes do projeto. Não especificada

Observações: Dirigido à comunidade acadêmica, é direcionado à prevenção sobre o uso de tabaco e álcool e, desse modo, à promoção à saúde. Importante a informação ser fornecida também através das artes cênicas e debate com os atores. Importante também observar que ações de médio e longo prazo estão previstas, o que caracteriza ação contínua. $O$ trabalho junto aos diretórios e centros acadêmicos é outro aspecto importante para envolver de modo mais consistente o corpo discente.

\section{Projeto 17}

Início: 2004 
Tema: Prevenção ao uso abusivo de drogas

Projeto incluído no PDI/PPI

Público-alvo: comunidade acadêmica

Objetivos:

- Possibilitar o repasse de informações prevenindo o uso indevido de drogas e a instalação da dependência

- Apoiar e divulgar os programas que trabalham com tratamento e recuperação de dependentes químicos

- Assessorar programas de reintegração social do dependente em recuperação e ações de apoio a recaídas

Ações (estratégias e táticas):

- Orientação a estudantes, servidores e familiares

- Encaminhamento a serviços especializados da IES e/ou da comunidade externa

- Atendimento de enfermagem às pessoas em crises existenciais e situacionais

- Atendimentos a usuários de drogas e familiares

- Atendimento na área de saúde

- Orientação em caso de overdose

- Encaminhamento para casos de dependência

- Atendimento na área de doenças sexualmente transmissíveis (DST e AIDS)

- Atendimento psicoterapêutico à comunidade, podendo ser individual, familiar ou grupal

- Encaminhamento para outros profissionais

- Palestras

- Pesquisa

- Informações no site

Avaliação: Não especificada 
Observações: O programa acolhe, orienta e acompanha o aluno com problemas e encaminha a outros profissionais quando necessário. Abrange toda a comunidade acadêmica.

\section{Projeto 18}

Início: 2001

Tema geral: Qualidade de vida

Projeto não incluído no PDI/PPI

Público-alvo: comunidade acadêmica

Objetivos:

- Criar, instituir, implementar, trabalhar e articular ações, campanhas, eventos, atividades, divulgando informações em favor da qualidade de vida da comunidade universitária

Ações (estratégias e táticas):

- Destaque para as ações que tem como foco o uso de drogas

- Campanha permanente de prevenção

- Palestras, oficinas e seminários

- Performances de alunos (artes cênicas)

- Elaboração de material impresso para distribuição

- Semana de atividades de promoção à saúde estendidas para comunidade regional, com palestras e apresentações culturais (extensão)

- Pesquisa sobre qualidade de vida

Avaliação: Não especificada

Observações: O projeto desenvolvido por esta instituição é direcionado à comunidade acadêmica, e tem como tema a qualidade de vida. $O$ consumo de drogas e sua repercussão na saúde é um dos conteúdos trabalhados. A 
participação dos alunos (artes cênicas) nas apresentações deve ser ressaltada nas ações com a comunidade regional.

A análise do conteúdo dos documentos evidenciou as categorias e subcategorias sintetizadas no Quadro 1. As categorias são identificadas por apresentarem caracteres comuns e têm como objetivo fornecer uma representação simplificada dos dados brutos.

Quadro 1- Categoria e subcategorias para análise do conteúdo dos documentos disponibilizados pelas instituições

\begin{tabular}{|c|c|}
\hline Categorias & Subcategorias \\
\hline Data de início & $\begin{array}{l}\text { - até ano } 2000 \\
\text { - a partir de } 2001 \\
\text { - não refere }\end{array}$ \\
\hline Público-alvo & $\begin{array}{l}\text { - apenas alunos } \\
\text { - comunidade acadêmica } \\
\text { - comunidade externa/inclui alunos }\end{array}$ \\
\hline Inclusão no PDI/PPI & $\begin{array}{l}\text { - incluído } \\
\text { - não incluído }\end{array}$ \\
\hline Objetivos & $\begin{array}{l}\text { - prevenir } \\
\text { - tratar } \\
\text { - promover a qualidade de vida } \\
\text { - integrar socialmente e reduzir de dano } \\
\text { - capacitar } \\
\text { - acompanhar e atender } \\
\text { - pesquisar-assessorar, consolidar o grupo } \\
\text { - divulgar programas } \\
\text { - reduzir de custos }\end{array}$ \\
\hline Ações & $\begin{array}{l}\text { - atividades de prevenção } \\
\text { - estratégias tradicionais } \\
\text { - capacitação }\end{array}$ \\
\hline
\end{tabular}




\begin{tabular}{|l|l|}
\hline Ações & - assistência e tratamento \\
& - pesquisa \\
& - produção de material educativo \\
& - atividades culturais \\
& - grupos de apoio \\
& - intervenções sistêmicas \\
- uso da mídia digital & - mudança de currículo \\
\hline Avaliações & - não especificadas \\
& - sistemática com uso de indicadores \\
& - por toda a instituição \\
\hline
\end{tabular}

Consolidando as categorias de análise observadas, em relação à data de início, foi identificado que dez projetos começaram até o ano 2000, quatro depois dessa data e quatro não referem data de início. Em relação à inclusão no PPI e PPI, conforme comentado anteriormente, embora considerados como diferentes documentos, ambos refletem compromisso formal da instituição com os órgãos reguladores oficiais. A subcategoria incluído no PDI/PPI aparece em 13 projetos e não está incluída em cinco.

Quando a categoria observada é público-alvo, embora de alguma forma todos os projetos permitam a participação do estudante, a subcategoria aluno aparece em quatro como foco principal; em sete a subcategoria observada é comunidade acadêmica; e em sete é comunidade externa, e inclui aqui usuários do sistema de saúde sem especificidade.

Analisando os objetivos, observa-se que, em todos, a subcategoria prevenir o consumo de drogas está presente. Algumas instituições descrevem de forma simples e direta: "criar, instituir, implementar, trabalhar e articular ações, campanhas, eventos, atividades, divulgando informações em favor da qualidade de vida da comunidade universitária", "ações e estratégias de prevenção", "fornecer informações e acolhimento antes do confronto com a mesma e a 
instalação da dependência" , "fornecer subsídios para construção de políticas sobre drogas" ou "criar e desenvolver projetos". Em outras esse objetivo parece implícito e é confirmado quando se observa a categoria ações, como "favorecer o desenvolvimento psicossocial discente, prestar atendimento psicológico e psiquiátrico ao aluno com dificuldade no aprendizado", "formação do indivíduo enquanto ser humano e social" ou "informações em favor da qualidade de vida".

Outras subcategorias frequentes na categoria objetivo são: tratamento (5 referências), que se apresenta como "assistir", prestar atendimento " psicológico, psiquiátrico", "tratar problemas relacionados ao álcool e outras drogas em nível de atenção primária, secundária e reabilitação"; promoção à saúde e qualidade de vida (ocorrências em 5 instituições), resumidas da seguinte forma: "criar, instituir, implementar, e articular ações e informações em favor da qualidade de vida" ou "promoção à saúde". Nessa ocorrência pode ser incluída a "formação do indivíduo enquanto ser humano". Ainda foram encontradas as subcategorias que têm como objetivo a integração social e redução de danos (3 IES). Em quatro projetos, uma das subcategorias dos objetivos era capacitação. Acompanhamento e atendimento ao aluno foram identificados em dois projetos, sendo que um refere como objetivo "contribuir com a evolução da abordagem científica das questões referentes à dependência química e envolvimento com drogas".

A capacitação aparece nos objetivos de quatro projetos: capacitar o aluno, professores, comunidade interna e externa e capacitar multiplicadores. Com uma única referência aparecem ainda as subcategorias: assessoria, consolidação do grupo de trabalho, divulgação de programas de reintegração social e redução de custos com os problemas decorrentes do consumo de drogas.

A análise da categoria ações no programa evidenciou, muitas vezes, planejamentos inespecíficos, incluindo "atividades de prevenção, ações a médio e longo prazo, um programa específico ou ações junto aos calouros", sem menção à metodologia ou a estratégias e instrumentos que serão utilizados (ocorrência em seis projetos).

As estratégias tradicionais, como eventos, campanhas, palestras, oficinas, seminários, mesas-redondas e simpósios aparecem em 13 projetos, associadas a 
outras atividades com características específicas: ciclo de palestras, campanhas permanentes, semanas de atividades.

Embora alguns projetos tenham como um dos objetivos a capacitação de alunos (bolsistas ou não), docentes, profissionais da saúde, voluntários e formação de multiplicadores, essas subcategorias aparecem também como ações propostas em oito projetos. A subcategoria assistência/tratamento, que aparece em 12 projetos, também apresenta diferentes aspectos. Alguns projetos detalham esse atendimento: "ambulatório de atendimento multidisciplinar, atendimento psicológico (individual e grupo), avaliação geral - história clínica (pregressa, atual e de ingestão), anamnese, exame físico e exames laboratoriais... voltado para os problemas relacionados ao uso, abuso e dependência do álcool e outras drogas." São mencionados, além de tratamento ambulatorial, triagem, atendimentos de urgência, "orientação em casos de overdose", terapia breve ou redução de riscos. Outros projetos são menos específicos, mas referem à participação de diferentes profissionais, como médicos (saúde em geral e psiquiatra), psicólogos, psicopedagogos, enfermeiros, nutricionistas, assistentes sociais.

Apesar de apenas uma instituição apresentar em seus objetivos a pesquisa, essa subcategoria aparece como uma das ações propostas em nove instituições, explicitadas de várias maneiras: "revisão teórica que subsidia a prática, amplia conhecimentos sobres efeitos da dependência no contexto familiar, verifica condições de vulnerabilidade social"; levantamento epidemiológico dos estudantes para diagnóstico do problema; promoção da qualidade de vida em geral. Em três instituições a publicação da experiência está prevista com uma coletânea sobre drogas, livro e produção de artigos, dissertações e teses. Uma subcategoria relevante encontrada é a produção de material educativo que ocorre em oito instituições e inclui: elaboração de informativos impressos (boletins folhetos e guias), placas e cartazes, manuais, portarias, fichas de acompanhamento e vídeos.

As atividades culturais representam uma subcategoria com ações diversificadas. Sete projetos incluem filmes (3), teatro (3), música (2), além de performance dos alunos, fotografia, cerâmica e pintura de desenhos no chão. 
A formação de grupos de apoio aparece em quatro projetos como uma estratégia de ação. Aspectos importantes foram incluídos nas ações planejadas, e em dois projetos aparece o planejamento, a construção e a implementação de intervenções sistêmicas. Sensibilizar e envolver lideranças ocorre no planejamento de três instituições, incluindo gestores, corpo docente e diretório acadêmico. O estágio, em disciplinas da graduação, extensão e atualização, aparece como subcategoria em duas instituições.

Apesar de atualmente a mídia digital estar ao alcance de todos e ser intensamente usada pelos estudantes, apenas em dois projetos ela faz parte das ações explicitadas - uma com o envio de e-mails e outra usando o site institucional como instrumento de informação. Apenas em uma instituição o projeto tem ações diretamente relacionadas com a mudança do currículo: "rever e implementar componentes curriculares que contemplem ações participativas e de educação preventiva".

Uma categoria prevista para a análise era a avaliação dos programas. A maior parte dos projetos não faz menção ao tipo de avaliação que será adotado. Treze IES foram incluídas na subcategoria não especificada. Em quatro projetos a avaliação é sistemática e com o uso de indicadores, sendo que em um (entre os quatro) a avaliação é feita por toda a instituição, mas não se especifica a metodologia que será utilizada. 
SE, NA VERDADE, NÃO ESTOU NO MUNDO PARA SIMPLESMENTE A ELE ME ADAPTAR, MAS PARA TRANSFORMÁ-LO; SE NÃO É POSSÍVEL MUDÁ-LO SEM UM CERTO SONHO OU PROJETO DE MUNDO, DEVO USAR TODA POSSIBILIDADE QUE TENHA PARA NÃO APENAS FALAR DE MINHA UTOPIA, MAS PARA PARTICIPAR DE PRÁticas com Ela coerentes. PAUlo Freire, PedAgogia da INDiGNAÇÃO, 2000 
O "I Levantamento Nacional sobre o uso de álcool, tabaco e outras drogas entre universitários das 27 capitais brasileiras" (Andrade et al., 2010) mostrou a prevalência do uso de álcool, tabaco e outras drogas, os problemas decorrentes desse consumo, os comportamentos de risco e a avaliação da saúde mental do universitário e constatou que $49 \%$ dos universitários brasileiros já fizeram uso na vida de alguma substância ilícita, enquanto na população brasileira em geral esse consumo é de $22,8 \%$, segundo estudos de Carlini (2007). Além disso, $86 \%$ dos universitários já fizeram uso na vida de álcool e $47 \%$ de produtos de tabaco, números acima dos descritos para a população brasileira no todo, identificando essa população universitária como vulnerável aos problemas e consequências associadas a esse consumo.

Esta pesquisa foi planejada partindo-se das hipóteses e delineando instrumentos de coleta de dados que pudessem responder à questão que deu origem ao estudo: a existência de projetos institucionais voltados para a prevenção, a orientação e a assistência ao estudante do ensino superior em relação ao consumo de drogas. A pesquisa qualitativa procura descrever e narrar, em vez de explicar; compreender mais que prever; e busca a possibilidade de extrapolar os dados para situações em contextos similares, não a generalização (Golafshani, 2003). Desse modo, a validade está relacionada com a coerência interna da pesquisa. A triangulação de métodos foi utilizada como estratégia para demonstrar a validade e a confiabilidade da pesquisa, pois permite uma visão multidimensional do problema (Lincoln; Guba, 2006), com utilização de múltiplos métodos, fontes e pesquisadores. Além da utilização de dois instrumentos pesquisa aos sites e questionário - para obtenção de um mesmo dado (existência, ou não, de programas institucionais), a busca nos sites foi feita por dois pesquisadores, que obtiveram os mesmos resultados.

Este estudo mostra-se inovador ao identificar, descrever e caracterizar projetos institucionais que proporcionem ao aluno do ensino superior brasileiro informações, orientações e assistência, uma vez que o consumo de drogas pelos universitários acarreta problemas de saúde, sociais e na vida acadêmica, como baixo desempenho escolar, falta às aulas e dificuldade de acompanhar sua classe. (US Department of Education, 2008). Por aproximar os estudantes em diferentes 
atividades curriculares e extracurriculares, ser lugar de adquirir conhecimento e promover a construção de valores, a escola é um espaço privilegiado para ações de prevenção ao consumo indevido de drogas.

Como limites deste estudo, a amostra representa alunos e IES apenas das capitais. Embora tenha havido variações nas características das amostras (gênero, curso, tipo de IES, região administrativa, número de cursos oferecidos pela IES), não se pode afirmar que as conclusões possam ser generalizadas para todas as instituições de ensino superior do Brasil. O enfoque foi nos projetos implantados voltados ao consumo de drogas, mas foram excluídas discussões sobre a questão social, as repercussões na saúde do estudante e seu aproveitamento escolar. Esses aspectos foram apenas considerados como indutores na necessidade de planejamento e implantação desses projetos. Como dificuldades encontradas, podemos citar que algumas IES inicialmente sorteadas se recusaram a participar da pesquisa, mesmo após múltiplos contatos. Entre as que aceitaram participar, algumas não responderam ao questionário enviado ao representante designado oficialmente pela instituição. Outra dificuldade foi a obtenção dos documentos para análise do conteúdo, pois, mesmo com insistentes pedidos, alguns não foram enviados e não eram apresentados nos portais. Curiosamente, quatro instituições declararam não estar ele ainda escrito. $O$ autopreenchimento dos questionários pode, desse modo, ser considerado como uma limitação do estudo.

Os números observados em relação ao consumo de drogas e suas repercussões na vida dos estudantes são preocupantes e necessitam de uma resposta ativa no sentido de prevenção, orientação ou assistência dos diferentes atores que convivem com esses jovens universitários. É da própria universidade que se espera uma intervenção positiva, que inclua no seu Projeto Pedagógico e no seu Plano de Desenvolvimento Institucional ações efetivas. Segundo Araldi (2012), essa problemática é um dos temas que emergem e que demandam uma ação da escola. As primeiras aproximações com o tema incluíam disseminação da informação, educação afetiva e programas alternativos; mais recentemente, foram incorporadas teorias de psicologia comportamental e treinamento de habilidades sociais de resistência, abordagens que reforçam as competências (Butvin et al., 2002), sabendo-se que é necessária uma mudança de comportamento e que o 
ambiente (campus) deve ser amigável e receptivo aos estudantes com dificuldades.

\subsection{Discussão dos dados obtidos através dos questionários}

Programas/serviços que sejam responsáveis pela saúde do estudante de forma geral e que incluam orientações e acompanhamento aos estudantes com dificuldades ou dúvidas em relação ao consumo de drogas existem em diferentes instituições. Desse modo, entre os principais tópicos a destacar está o fato de que, embora grande parte dos alunos pesquisados saiba da existência, em sua IES, de programa de atendimento à sua saúde, são poucos os que buscam esse serviço. Segundo os alunos, menos de um terço relata ter recebido informações a respeito do uso de drogas e de seu impacto na saúde, embora mais de metade das instituições divulguem eventos pontuais e informações a esse respeito em seus sites oficiais. (Essas informações não são identificadas pelos alunos.) Entre as IES que participaram deste estudo, 27\% dizem possuir um programa de prevenção, orientação ou assistência aos alunos quanto ao consumo de drogas, mas apenas 18 programas foram obtidos para a análise, e causa estranheza quatro instituições declararem que o projeto não estava escrito, embora assumam sua existência. Todos os projetos analisados (18) tinham a prevenção como um dos objetivos, direta ou indiretamente.

A preocupação com o tema extrapola os muros das instituições: alguns programas são voltados também para a comunidade externa e incluem o aluno; em outros o aluno é capacitado para participar como multiplicador das informações para a comunidade fora da IES, faltando nesses projetos ações voltadas diretamente para o corpo discente.

Diferentes pesquisas, citadas anteriormente, mostram o consumo de drogas pelos estudantes universitários, mas são escassos os estudos que mostram a percepção desses alunos sobre a atenção que a escola, como responsável pela formação integral do aluno, dedica ao tema. 
A responsabilidade da escola superior vai além de transmitir conhecimentos e capacitação restrita à área profissional de formação: ela deve ter um papel ativo na formação desse jovem como pessoa e cidadão. As palavras de Paulo Freire em Pedagogia da Esperança (1992) mostram que a formação do indivíduo se dá na e pela sociedade na qual ele está imerso e na qual deve viver e sobreviver:

Não importa em qual sociedade estejamos, em que mundo nos encontremos,
não é possível formar engenheiros ou pedreiros, físicos ou enfermeiras,
dentistas ou torneiros, educadores ou mecânicos, agricultores ou filósofos,
pecuaristas ou biólogos sem uma compreensão de nós mesmos enquanto seres
históricos, políticos, sociais e culturais, sem a compreensão de como a
sociedade funciona. E isto, no treinamento supostamente técnico, não se dá.

Ouvir os estudantes sobre outros aspectos por meio da análise de suas respostas ao questionário específico foi relevante.

Formar estudantes que irão viver na sociedade como cidadãos críticos e responsáveis, como está nas Diretrizes Curriculares dos Cursos de Graduação (1997), requer algo mais que uma matriz que contemple os conteúdos inerentes à formação profissional: deve-se oferecer espaços e ocasiões para que o aluno possa praticar e exercer sua criatividade e análise crítica, considerando as dimensões éticas e humanísticas, desenvolvendo atitudes e valores orientados para a cidadania, pois, como diz Freire (1996), devemos formar "mulheres e homens, seres histórico-sociais, nos tornarmos capazes de comparar, de escolher, de decidir, de romper. Por tudo isso, nos fazemos seres éticos".

Os 12.711 estudantes que participaram da pesquisa estão distribuídos em 100 instituições das cinco regiões administrativas, sendo 52 públicas e 48 privadas. São representados por $43 \%$ de homens e $57 \%$ de mulheres, tendo, portanto, uma distribuição semelhante quando observamos o gênero e o tipo de IES que frequentam. Como esses questionários não eram identificados, não é possível relacionar as respostas dos alunos com a respectiva instituição de origem.

Mais de metade (58\%) dos alunos sabe da existência de um programa de atendimento à saúde em sua escola, sendo a saúde considerada em um sentido amplo que inclui - mas não se limita a - os aspectos relacionados ao consumo de drogas, lícitas e ilícitas. Os alunos de ciências biológicas (incluindo a área de 
saúde) são os que mais conhecem a existência dos programas, talvez pela própria natureza do curso que diretamente estão vinculados à vida e saúde.

O fato importante é que, se se levar em conta o total da população pesquisada, apenas um número muito pequeno de alunos utiliza o serviço, e é entre os alunos de ciências biológicas que existe uma procura um pouco maior. Continua a ser um número baixo de utilização de um serviço disponível lembrando que esses serviços de saúde não são exclusivamente direcionados ao consumo de drogas, mas à saúde como um todo, como um direito social (Constituição da República Federativa do Brasil, artigo 196). Esses serviços precisam ser mais bem divulgados e conquistar a confiança dos estudantes para sua melhor utilização. Embora conheçam o serviço de cuidado à saúde que é disponibilizado nas instituições para atendimento ao aluno, a utilização do serviço é mínima, e a escola deve avaliar esse serviço e investigar as razões de sua não utilização pelos estudantes.

Um aspecto importante da prevenção ao consumo de drogas é a disponibilização de informações sobre seu uso e seus impactos sobre a saúde. Por essa razão foi perguntado aos alunos se, nos últimos 12 meses, tinham recebido informações na sua IES focadas nessa temática. Menos de um quarto dos estudantes que responderam ao questionário afirma tê-las recebido, uma porcentagem baixa, demonstrando a falta de comunicação e a necessidade de divulgar as ações propostas. Novamente, em decorrência das peculiaridades dos cursos da área biológica, a porcentagem de alunos foi maior. É importante lembrar que o tema faz parte dos currículos dessa área e entra como conteúdo programático em diferentes disciplinas, o que leva a que um maior número de alunos tenha acesso a informações, como conteúdos obrigatórios do currículo. Em relação à região administrativa, tipo de IES e gênero, as porcentagens são próximas, e não existem diferenças significativas. Isso mostra que a deficiência em transmitir informações que ajudem a compreender e dimensionar o problema do consumo de drogas (licitas e ilícitas) é uniforme e pouco trabalhado nas instituições pesquisadas. Esses dados, comparados com a divulgação de diferentes atividades, eventos pontuais ou campanhas que abordam o tema nos sites institucionais, que ocorrem em pelo menos metade das instituições, mostra 
que as informações trabalhadas nessas ocasiões não atingem de forma importante o público estudantil. Portanto, a comunicação é falha e a adesão dos alunos às atividades não é efetiva, talvez por uma abordagem inadequada do problema.

Considerando-se que projetos baseados apenas em ações informativas esporádicas, que não induzam a mudanças de comportamento, caracterizam uma forma reducionista de encarar o problema, o combate ao consumo inadequado de drogas inicia-se com o fornecimento de informações, mas apenas elas - muitas vezes fornecidas de modo inadequado - não transformam a realidade dos campi. "A teoria sem a prática vira verbalismo, assim como a prática sem teoria vira ativismo. No entanto, quando se une a prática com a teoria, tem-se a práxis, a ação criadora e modificadora da realidade." (Freire, 2000).

Os dados observados sobre a informação deficitária que os alunos recebem estão de acordo com o que Polymerou (2007) diz a respeito do Reino Unido, onde falta informação sobre os programas e repercussão na extensão do dano que o abuso de drogas e álcool causa nos estudantes e na universidade, mostrando uma realidade semelhante à observada neste estudo. Segundo Sanchez (2011), entre usuários de drogas prevalece a falta de informações - ou elas são incompletas -, o que é ineficaz quando se fala em prevenção. Por isso não se deve basear programas e prevenção só na divulgação de informações - isso seria apenas uma parte do processo. Deve, portanto, ser planejado um projeto duradouro e consistente, com ações que gerem resultados a curto, médio e longo prazos (Mariz, 2003).

Além de atingirem só uma pequena parte dos estudantes, as informações sobre o uso de álcool e outras drogas e repercussões na saúde ocorrem principalmente através de metodologias tradicionais, como aulas e palestras, o que está de acordo com os dados observados na análise do conteúdo dos documentos enviados (projetos), que mostra que em 13 projetos essa metodologia é utilizada. A comunicação escrita (cartas, comunicados, panfletos, pôsteres informativos), assinalada por metade dos alunos, mostra que a preocupação em produzir material didático (que ocorre em 8 projetos) é uma forma da informação, adaptada à realidade local, chegar aos alunos. 
O envolvimento das lideranças estudantis é um meio pouco explorado, e menos de um quarto dos projetos mostra essa preocupação. Os alunos assinalam a alternativa leitura em publicações estudantis como uma forma importante de obter informações, e essa é uma tática que pode ser usada, estimulando o corpo discente a participar dos projetos. Poucos alunos participaram de algum curso especial sobre álcool e outras drogas compatível com os documentos apresentados pelas instituições, que mostram mais cursos dirigidos à formação de profissionais da educação ou de saúde, nos quais a participação estudantil é restrita.

Embora a escola se configure como um espaço privilegiado de informação e educação, os alunos não recebem, em sua maioria, esse conhecimento sobre drogas na IES, bem como não se apropriam de forma adequada dos espaços que possam existir para atendimento e discussão.

Anderson et al. (2009) fizeram uma metanálise dos programas efetivos de prevenção de problemas relacionados ao álcool no ensino superior. Concluíram que apenas a educação escolar não diminui o dano, mas auxilia a diminuí-lo com o fornecimento de informações sobre as consequências do uso de drogas. Reafirmam que o oferecimento das informações é um passo para a prevenção, mas não o único e que, talvez, possa ser definido como o passo inicial.

Em relação ao apoio e à ajuda que o estudante acredita encontrar em sua instituição (conselho, professores ou um adulto) para reduzir ou parar o consumo de drogas, menos de metade acredita ser possível ou muito possível de ser obtido, e apenas $9 \%$ acham não ser possível encontrar essa ajuda. Mais da metade não sabe ou não respondeu. Portanto, se forem somados os alunos que não sabem, não responderam ou não acreditam nessa possibilidade de ajuda, temos $60 \%$ da população pesquisada. Independentemente da existência de um programa, eventos e campanhas, a escola deveria ser um lugar de acolhimento para os estudantes, bem como as políticas de acompanhamento psicopedagógico e as áreas de convivência para os estudantes deveriam estar incluídas no PDI, conforme orientação da Secretaria de Educação Profissional e Tecnológica da Secretaria de Educação Superior (Brasil, 2007). 
O ambiente escolar, do ensino fundamental ao superior, deveria ser sempre um lugar de acolhimento, no qual os alunos estivessem seguros de encontrar apoio. Esse conceito é reforçado com o que declara Paulo Freire (2010):

Escola é o lugar onde se faz amigos, não se trata só de prédios, salas, quadros, programas, horários, conceitos... Escola é, sobretudo, gente, gente que trabalha, que estuda, que se alegra, se conhece, se estima... Nada de conviver com as pessoas e depois descobrir que não tem amizade a ninguém; nada de ser como o tijolo que forma a parede, indiferente, frio, só. Importante na escola não é só estudar, não é só trabalhar, é também criar laços de amizade, é criar ambiente de camaradagem, é conviver, é se 'amarrar nela'! Ora, é lógico. numa escola assim vai ser fácil estudar, trabalhar, crescer, fazer amigos, educar-se, ser feliz."

Apesar de 100 instituições aceitarem participar da pesquisa, nem todas responderam ao questionário e apenas um terço declarou ter um projeto que inclui ações de prevenção, orientação e/ou assistência ao discente. A maioria das instituições que tem um projeto com essas finalidades apresenta cursos na área de saúde numa proporção maior do que entre as instituições do total da amostra. Nesses cursos o tema drogas se inclui nos currículos, permeando diferentes disciplinas (bioquímica, psicologia, psiquiatria, saúde coletiva, epidemiologia e outras), o que se configura como um facilitador e modo de introduzir a discussão desse tema.

No Brasil existem múltiplas políticas públicas para o enfrentamento do consumo de drogas, mas não existe obrigação legal para que instituições de ensino superior mantenham programas de prevenção, orientação ou assistência a seus alunos. Nos Estados Unidos, para receber recursos federais, as faculdades e universidades devem fornecer ao estudante informações sobre suas políticas de prevenção, com diretrizes formuladas desde 1989 (Faden et al., 2009). Essas diretrizes exigem a divulgação de informações sobre as normas que regulamentam o uso de álcool e drogas e sobre o risco à saúde, associadas às informações sobre o uso ilícito de drogas e álcool, bem como qualquer aconselhamento, tratamento, programa de educação, disponíveis para o aluno, e uma declaração de 
que a instituição vai aplicar sansões para a violação de seus padrões de conduta, descrevendo essas sanções.

Neste estudo, entre as escolas participantes da pesquisa que declaram possuir um projeto, o maior número possui regime administrativo público, o dobro das instituições com regime administrativo privado. Esses dados sugerem uma maior inserção das instituições públicas no enfrentamento ao consumo de drogas, pois, no total da amostra, o número de instituições públicas e instituições privadas tinha uma distribuição paritária. No Nordeste, todas as IES que declaram possuir um programa de prevenção, orientação e/ou assistência em relação ao consumo de drogas têm regime administrativo público.

Em sete das 27 instituições que responderam ter um projeto, a busca no site não mostrou a presença de um projeto de prevenção, orientação e/ou assistência em relação ao consumo de drogas voltado ao estudante, apenas eventos pontuais. De certo modo, não ter o documento escrito foi considerado como ausência de um projeto, o que não significa a inexistência de ações relacionadas ao problema do consumo de drogas entre os estudantes. Novamente é necessário rever o problema de divulgação no site e como as informações são disponibilizadas nesse meio.

Entre as 27 IES que declaram possuir um projeto, apenas em 17 eles fazem parte do Projeto Pedagógico e do Plano de Desenvolvimento Institucional, documentos exigidos das IES, caracterizando um compromisso oficialmente assumido pela instituição com os órgãos reguladores. Isso mostra que, apesar de as instituições saberem da importância de uma intervenção em prevenção, orientação e/ou assistência ao aluno em relação ao uso de drogas, nem todas assumem oficialmente o compromisso. Esses dois documentos têm finalidades e periodicidade diferentes, mas cada um deles representa um compromisso que será considerado na avaliação e no recredenciamento da instituição.

Quando foi solicitado o projeto para as instituições, quatro instituições declararam que ele ainda não havia sido escrito ou que estava em fase de elaboração. Embora existam atividades de prevenção, orientação e/ou assistência em relação ao consumo de drogas, ainda não se configuram como um projeto escrito. Desse modo, apesar de o panorama do consumo de drogas entre 
universitários ser preocupante, essa preocupação não se traduz em um efetivo planejamento institucional.

Em quatro das 27 instituições, o programa é voltado apenas ao aluno; em 14, o programa é voltado para a comunidade acadêmica, o que é importante, pois o entorno influencia e até determina a eficácia das ações propostas que, nessas instituições, envolvem, além dos estudantes, o corpo docente, o técnico e o administrativo na busca de um ambiente saudável. Diferentes autores, como Dejong (2007), Moriz (2003) e Polymerou (2007) ressaltam a importância do envolvimento de todos os componentes da comunidade acadêmica nas diferentes ações que envolvem as políticas institucionais focadas no consumo de drogas.

Em nove instituições o projeto é aberto, dirigido a usuários do sistema de saúde, não havendo ações específicas voltadas para o corpo discente, mas preocupação com o usuário em geral, e o aluno participa ora como usuário, ora como agente multiplicador. É importante a inserção da universidade na comunidade a que pertence, mas o corpo discente é o foco de formação do ensino superior e responsabilidade da instituição. As IES mostram com esse direcionamento uma adesão às políticas nacionais de enfrentamento do consumo de drogas, cumprindo seu papel social de divulgação do conhecimento e assistência à comunidade na qual a IES está inserida, seu entorno. Apenas um dos projetos voltados exclusivamente para o corpo discente é específico no enfrentamento do consumo de drogas pelos estudantes - nos demais 0 acolhimento e a orientação geral do estudante são a meta do programa apresentado, mas a prevenção, a orientação e/ou a assistência estão incluídas direta ou indiretamente.

DeJong (2007) ressalta que os projetos institucionais bem avaliados apresentam ações que têm como foco o indivíduo, o grupo, a instituição como um todo, a comunidade e políticas públicas de enfrentamento estaduais e federais. Desse modo, o fato de incluir a comunidade nas ações e participando dos eventos traz uma atuação expandida, mas, em algumas instituições, o problema do consumo de drogas pelo estudante está diluído no projeto, não havendo ações diretamente voltadas para esse público. 
O acesso do aluno ao programa se dá, na maior parte dos projetos, por busca espontânea direta ou após atividades que divulgam o programa, e a necessidade de ser encaminhado ou referenciado por professor ou departamento ocorre em 13 instituições. É importante que o aluno possa chegar ao programa de diferentes formas, facilitando-Ihe e estimulando a participação. Muitas vezes tornase necessário que alguém da confiança do aluno (professor, coordenador, preceptor ou um de seus pares) o sensibilize e indique a possibilidade de orientação prevista nos diferentes projetos.

Para que os programas tenham êxito, eles devem incluir efetivamente toda a comunidade acadêmica, e a divulgação ampla dos projetos através de diferentes técnicas facilita esse conhecimento. Os meios de divulgação utilizados pelas instituições (a maioria divulga seus programas) variam - mídia eletrônica, impressa, audiovisual, publicações, além de palestras e debates - e possibilita acesso ao público-alvo de diferentes modos. Enquanto metade dos alunos refere ter obtido informações em aulas, palestras, reuniões, esse não é o meio de divulgação mais usado pelas escolas. Os instrumentos de divulgação interna dos projetos necessitam de avaliação e ressignificação para que possam atingir o público-alvo. Curiosamente, duas instituições não sentem necessidade de divulgação interna de seus programas, acreditando já serem conhecidos, esquecendo-se de que novos alunos chegam à escola a cada ano e de que os projetos, para obterem adesão, precisam ser constantemente divulgados. Algumas escolas que possuem projetos com um público mais abrangente (comunidade externa) os divulgam também fora da instituição. A divulgação para a comunidade externa é feita de diferentes maneiras (rádio, internet, cartazes, participação em eventos), procurando atingir toda a população-alvo, mas os sites institucionais são pouco explorados. A importância desse meio de comunicação é salientada por Faden et al. (2009), que ressaltam a importância das divulgações on-line, as quais ficam mais disponíveis e acessíveis aos alunos e a outros interessados, sem limite de local e horário, e refletem um maior engajamento das escolas de ensino superior na questão do uso de drogas no campus. A autora chama ainda atenção para o fato de que as informações estão dispersas nos sites, e essa foi também uma dificuldade encontrada na apuração dos dados deste estudo. Para que esse 
problema fosse minimizado, foram adotados três modos diferentes de busca de informações nos sites institucionais.

Os trabalhos que avaliam os projetos implantados nas instituições de ensino superior mostram a importância do envolvimento, nesses programas, da comunidade acadêmica e do entorno do campus, para que o programa de prevenção seja efetivo (DeJong, 2007). Desse modo, o fato de ser parte de um projeto de extensão faz com que a academia ultrapasse seus muros e envolva a comunidade/sociedade na qual a IES se localiza. Direcionando para um maior número de participantes, 17 das IES assumem o programa como parte de sua atividade de extensão, sendo, em 7 , o setor de extensão/assuntos comunitários 0 responsável por ele.

Os cursos da área de saúde apresentam em seu conteúdo curricular a abordagem do tema em diferentes disciplinas, fazendo parte dos conhecimentos que o aluno deve adquirir na sua formação profissional. Isso não implica que o tema deste estudo se destaque nos conteúdos programáticos. Esse tema é muitas vezes abordado em estágios curriculares, obrigatórios ou não. Em duas instituições o conteúdo sobre o tema, que é oferecido em diferentes disciplinas curriculares, é considerado como um projeto de prevenção. É importante salientar que o conhecimento por si só não implica resultado positivo; esse resultado deve levar à mudança de comportamentos, um passo importante para a prevenção ao uso de drogas (DeJong, 2007).

A importância do problema levou 11 instituições a criar um grupo específico com a finalidade de implantar e executar o projeto, mas em três IES apenas um profissional é responsável pelo programa, dependendo o cuidado ao aluno de iniciativas individuais, o que provavelmente acarreta problemas na divulgação e operacionalização do projeto e reflete a não existência de um compromisso coletivo e institucional com o tema. Dejong (2007) chama a atenção para a necessidade de um grupo permanente, que se mobilize e seja representativo dos diferentes setores do campus, incluindo o pessoal administrativo. Mariz (2003) ressalta a necessidade de uma equipe de coordenação do projeto, não apenas para que o programa seja mantido por um período longo, mas para orientar as avaliações e redirecionar o programa em busca da efetivação dos objetivos. 
Novamente é pontuada a necessidade de não ser um simples evento, mas um programa contínuo caracterizando um processo de mudança orientado por uma efetiva avaliação.

Os Núcleos/Grupos de apoio psicopedagógico ao discente estão presentes em 66,7\% das 27 IES que possuem um programa, enquanto na amostra inicial está presente em 31\% (entre 100). Por esses dados pode-se inferir que esse núcleo é um estimulador para a existência de programas de prevenção, uma vez que ele recebe e orienta alunos com problemas (demanda espontânea ou encaminhamento). A existência de um serviço de atendimento à saúde do aluno, que inclui orientação, sinaliza a preocupação dessas instituições em desenvolver um programa voltado ao tema drogas. Em três instituições as ações desse grupo são identificadas com seus programas de prevenção, orientação ou assistência no consumo de drogas.

Já foi comentada a inserção do ensino e da extensão nos projetos institucionais que têm como tema "prevenção, orientação e assistência ao aluno, relacionadas ao uso de álcool, tabaco e outras drogas”. O terceiro eixo de atividades inerentes às instituições de ensino superior no Brasil é a pesquisa. Entre as escolas que apresentam programas de prevenção, orientação ou assistência em relação ao uso de drogas, 14 fazem pesquisa nessa área, com a constituição de núcleos estruturados. Muitas dessas pesquisas envolvem alunos (alguns com bolsa). Nessas instituições, a preocupação ultrapassa o apoio ao aluno no tema e alcança um novo patamar, o de produção de conhecimento científico.

\subsection{Discussão dos dados obtidos na análise dos projetos}

Em relação à análise do conteúdo dos projetos obtidos, dez deles tiveram seu início há mais de dez anos, embora nenhum apresente avaliações desses anos do projeto implantado. Embora tenham sido executados por muito tempo, não há relato de avaliações que pudessem nortear seu percurso, nem existem evidências da efetividade das ações planejadas, com mudança da realidade do 
consumo de drogas no campus ou em seu entorno. A inclusão do projeto no PPI ou PDI ocorre em 14 projetos, indicando um comprometimento oficial da instituição no enfrentamento ao consumo de drogas, uma vez que esses documentos são considerados e sua execução cobrada no processo de avaliação institucional para fins de recredenciamento. Embora os projetos relatem sua inclusão no PPI e no PDI, novamente a avaliação de sua efetividade não aparece contemplada.

Ainda que o aluno possa participar/ser atendido por todos os programas enviados, alguns programas são voltados para o público em geral, não é o aluno o público-alvo das ações especificas de prevenção, orientação ou assistência. São de extrema importância os programas (sete) que envolvem toda a comunidade acadêmica, porque todos os atores que convivem no ambiente escolar devem participar ativamente dos projetos, para que sejam efetivos.

Dos quatro programas voltados apenas para os estudantes, em dois não existem ações diretamente focadas para o atendimento do aluno, mas existe demanda para esse acolhimento (procura espontânea ou encaminhamento). Orientação e encaminhamento podem ocorrer através dos núcleos psicopedagógicos, embora as duas instituições tenham entendido essas atuações como parte de um programa institucional voltado para o enfrentamento ao consumo de drogas. Em dois programas com foco exclusivo nos estudantes, o consumo de drogas faz parte explícita dos objetivos, e ações especificas de prevenção, orientação e assistência estão planejadas.

Todos os projetos apresentam em seus objetivos, direta ou indiretamente, a prevenção, uma etapa que se destaca no enfrentamento ao consumo de drogas. Moriz (2003) considera a prevenção como a forma mais eficiente de combater o consumo indevido de drogas. A análise dos documentos mostra a preocupação das IES não apenas em implementar diferentes modos de prevenção, mas de articulá-los - desde fornecer informações (modo menos dispendioso) até elaborar políticas de enfrentamento. Os projetos mais amplos trazem promoção à saúde, qualidade de vida e formação do indivíduo "como ser coletivo". O tratamento e o acompanhamento do usuário, bem como a redução de danos e a integração social aparecem como objetivos. DeJong (2007) afirma que uma das áreas-chave de enfrentamento ao consumo de drogas é a informação que se traduza em mudança 
de atitude e mudança ambiental dos fatores, que contribua para o entendimento do tema, ofereça aos alunos estratégias de proteção à saúde, que intervenha e que trate dos alunos com problema no consumo de drogas.

Ações focadas na prevenção, na orientação ou na assistência individual ou coletiva são essenciais, mas a formação de multiplicadores e lideranças, como aparece em vários projetos, propiciará um aumento da população atendida pelo programa (Mariz, 2003), bem como a capacitação de profissionais de educação e saúde que possam participar dos projetos. A equipe responsável deve estimular outras pessoas da instituição, e fora dela, a participar do projeto, direta e indiretamente, nas ações programadas, para ajudar no trabalho dessa questão com os alunos e demais envolvidos. Com isso, aumenta gradativamente o número de pessoas preparadas e diminuem erros que podem acontecer na abordagem do tema.

Muitas vezes, ao analisar os projetos, percebem-se os limites estreitos que existem entre os seus objetivos e as ações planejadas, uma vez que, em alguns projetos, a metodologia e os objetivos são sobrepostos e as ações descritas de uma forma genérica ("ações de prevenção"). Os projetos analisados não apresentam detalhes da metodologia utilizada. As estratégias mais utilizadas são as tradicionais de divulgação de informações em um ambiente escolar nas quais o "especialista" repassa seus conhecimentos para diferentes plateias. Importante ressaltar que são essas metodologias as mais assinaladas pelos estudantes em relação às informações recebidas sobre o assunto nos últimos 12 meses na IES. Isso mostra que as estratégias e os métodos utilizados não necessitam ser sempre inovadores, mas diversificados, para que possam alcançar os estudantes de diferentes modos, e em diferentes ocasiões, através de diferentes meios. Nesse sentido, são planejadas diferentes atividades culturais e mídia digital. Em relação a meios de comunicação digital, percebe-se que estão sendo pouco explorados pelas IES, que incluem apenas o envio de e-mails e divulgação parcial no site institucional, não utilizando formas de comunicação digital consagradas pelos estudantes, como redes sociais, sites, aplicativos para smartphones.

Os estudantes das instituições de ensino superior pertencem à geração $Y$, também chamada Geração Millennials, Geração da Internet e iGeração. São 
pessoas nascidas entre 1980 e 2007, que já que já foram criadas com computador, internet e conectividade, e desenvolveram afinidade com o uso de novas tecnologias (Lipkin, Perrymore, 2010). Portanto, esses meios de comunicação devem ser explorados nos projetos institucionais para difusão de informações e promover discussões e atividades colaborativas. Oblinger (2005) descreve esses alunos:

Um estudante caminha pelo campus ouvindo um iPod, um outro está envolvido em mensagens de texto em seu telefone celular. Durante a aula, eles estão pesquisando, enviando mensagens instantâneas e jogos - muitas vezes ao mesmo tempo. Mais propensos a usar a biblioteca como um local de encontro do que um recurso, esta é a Geração Net.

Múltiplas estratégias em diferentes níveis, para cada objetivo formulado, aumentam a probabilidade de o objetivo ser alcançado e, nesse sentido, sete projetos planejam atividades culturais com a participação de alunos, algumas vezes como espectadores (filme, teatro, musica), outras vezes com a participação ativa em artes cênicas, fotografia, artes plásticas (cerâmica e pintura) e participando de discussões e comentários ao final das apresentações. É importante a participação ativa na prevenção e, como já foi visto, a geração que hoje frequenta o ensino superior está mais propensa ao ambiente participativo, com atividades vivenciais e sensoriais (níveis físico e virtual) e prefere aprender fazendo em vez de contar ou ler (Jones et al. 2010), isto é, aprende de forma diferente das gerações anteriores.

As ações incluídas na subcategoria assistência/tratamento aparecem em 12 dos 18 projetos analisados e incluem ambulatórios de triagem, de clínica e atendimentos psicológicos e psicoterapêuticos, com terapia breve (foi constatada a existência de atendimento de urgência em uma instituição). Importante destacar que atendimentos multiprofissionais também estão descritos. Diferentes profissionais promovem diferentes e complementares olhares. Um problema complexo como o consumo de drogas requer uma abordagem multiprofissional: não apenas atividades com diferentes profissionais trabalhando em conjunto, mas 
também o planejamento com gestores (olhar político), educadores (estratégias pedagógicas) e especialistas das diferentes facetas relacionadas ao consumo de drogas.

Os projetos de prevenção ao uso de drogas por estudantes do ensino superior mais bem avaliados ressaltam a importância da atuação das lideranças do campus (estudantes, docentes, funcionários e gestores) para que seus resultados sejam expressivos (Muraskin, 1993; Delong, 2007; Polymeron 2007). Nos documentos analisados, apenas três fazem menção ao estímulo ao envolvimento e à sensibilização das lideranças. Todo projeto a ser implantado nos campi depende das lideranças acadêmicas para adesão, execução e avaliação das ações.

A publicação Shool-based drug abuse prevention (2009), da Public Safety (Canadá) sobre avaliação de programas de prevenção do abuso de drogas diz que não existe um único conjunto de critérios para a avaliação, e que mesmo programas considerados exemplos podem, em um contexto diferente, não ter a mesma eficácia. Além disso, os efeitos reais de um programa não duram no longo prazo, eles devem ser reestruturados e otimizados. A publicação destaca a necessidade de processos e de avaliação rigorosa, consistente, transparente e de longo prazo.

A produção de material educativo (em oito instituições) é um aspecto importante, pois esse material, além de contribuir para a divulgação e a fixação do conhecimento apreendido, é instrumento de ensino de práticas e atitudes adequadas no enfrentamento do consumo de drogas e um material que pode ser apresentado fora da instituição, servindo de reforço para a elaboração de outros projetos.

A informação tem papel decisivo quando se fala de prevenção, mas é apenas o primeiro passo. O saber pode não alterar o panorama observado de consumo de drogas pelos estudantes e suas consequências. Há necessidade de mudança de atitudes e, para que isso ocorra, o ambiente do campus deve ser restritivo ao consumo. É necessário que outros aspectos sejam incorporados pela comunidade acadêmica: saber fazer, saber ser e saber conviver (Delors, 2000). Nesse sentido, em dois projetos o planejamento, a construção e a implementação 
de ações sistêmicas estão previstos e em apenas uma instituição o projeto especifica a necessidade de "rever e implementar componentes curriculares que contemplem ações participativas e de educação preventiva ao uso de drogas", assumindo que as ações curriculares devem ser desenhadas de modo coletivo, integrando os conteúdos e permitindo um conhecimento não linear entre os diferentes locus de ensino na universidade.

A avaliação, que se constitui como parte essencial de todo planejamento, não é especificada na maioria dos projetos, o que é preocupante. Infelizmente, a maioria dos gestores tende a associar a avaliação como uma medida de resultados finais, e os planejadores não conseguem pensar em avaliação até depois de seus programas e políticas já implantados. Contudo, se a avaliação for pensada como integrante do processo de planejamento, vai estimular a reflexão de todo o programa: missão, metas, objetivos e atividades direcionadas para que os objetivos sejam cumpridos (Saltz e DeJong, 2002).

A avaliação dos programas deve ser seguida da comunicação de seus resultados para todos os envolvidos e toda a comunidade, para que sejam informados da influência da intervenção (prevenção, orientação ou assistência) no campus. Sem essa retroalimentação, o impacto inicial que possa ter ocorrido com a implantação do programa pode diminuir ou até mesmo desaparecer com o passar do tempo. Além disso, essa devolutiva tem a tendência de estimular adesões, mesmo quando incialmente os resultados foram menores do que o esperado, pois a discussão dos resultados e a análise dos pontos fracos reforçam a confiança dos envolvidos em seguir e melhorar a intervenção, estimulando os instrumentos ditosos e melhorando as falhas (Saltz e DeJong, 2002).

Nos quatro programas que a incluem nos projetos apresentados, a avaliação é descrita como sistemática, com a construção de indicadores, mas eles não apresentam o modo como isso será executado, quais os indicadores ou quem será responsável por ela. Muraskin (1993) pontua que a avaliação efetiva ocorre a partir da elaboração de objetivos claros, mensuráveis e realistas. Se esses forem excessivamente otimistas e não mensuráveis, pode não ser possível demonstrar o êxito do trabalho, mesmo quando ele tenha sido benfeito. 
Os objetivos dos programas apresentados são, muitas vezes, mal definidos (criar e articular ações ou visa a formação do indivíduo como ser humano), ficando difícil um instrumento de avaliação que possa dar conta desse propósito. A finalidade da avaliação é identificar o efeito do programa no cotidiano do campus, ajudando a perceber se o programa tem alguma influência no conhecimento e, principalmente, nas atitudes de seus participantes, para prevenir ou diminuir o consumo de drogas e readequar esse programa para que tenha maior eficácia. Para que isso ocorra, são três as dimensões da avaliação (Muraskin,1993) - do processo, que ocorre durante a execução do programa (adequação das abordagens instrumento, métodos); dos resultados (efeitos imediatos ou diretamente ligados ao programa) e do impacto (analisando várias ações que se potencializam e efeitos observados que perduram) - e ela deve estar planejada desde a elaboração do projeto.

Essa realidade, que coloca frente a frente o consumo de álcool, tabaco e outras drogas pelo estudante universitário e a inserção das instituições em programas que possam prevenir orientar ou assistir esse aluno, subsidia essas reflexões e inquietações que levam em conta o papel social da Universidade e o compromisso com a formação integral de seus alunos. 
NÃO, NÃO TENHO CAMINHO NOVO.

O QUE TENHO DE NOVO

É O JEITO DE CAMINHAR

APRENDI

(O CAMINHO ME ENSINOU...)

A CAMINHAR CANTANDO

COMO CONVÉM

A MIM

E AOS QUE VÃO COMIGO

POIS JÁ NÃO VOU MAIS SOZINHO

THIAGO DE MELLO, 1996

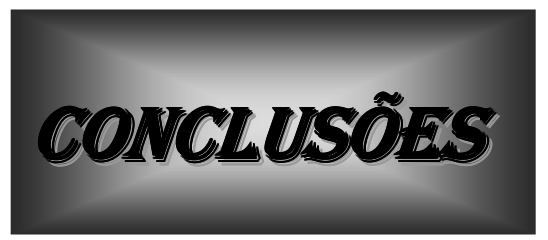


Embora existam evidências de que experiências com drogas lícitas e ilícitas ocorram dentro dos campi das universidades, e que os universitários merecem uma atenção especial, projetos que tenham como foco a prevenção, a orientação ou a assistência em relação ao consumo de substâncias psicoativas não são uma exigência legal de nosso sistema de ensino e, portanto, sua presença depende apenas da vontade política e pedagógica de nossas instituições.

A existência desses projetos nas IES brasileiras se configurou com o eixo norteador deste estudo, permeou e orientou a escolha dos instrumentos de coleta de dados, bem como sua análise, e acompanha estas últimas considerações.

As respostas dos alunos indicam a necessidade de maior esforço das instituições no sentido de divulgar os serviços (de saúde) oferecidos a eles. Além de saberem da sua existência, os estudantes devem ter confiança e utilizá-los. As informações sobre o consumo de drogas são percebidas por um pequeno número de estudantes, mostrando, portanto, a necessidade de um melhor planejamento das atividades, no sentido de diversificar e se aproximar da linguagem do jovem. A comunicação entre a IES e seus estudantes está sendo falha. Freire (1996) afirma que "a tarefa do educador que pensa certo é, exercendo como ser humano a irrecusável prática de interagir, desafiar o educando com quem se comunica e a quem se comunica, produzir sua compreensão do que vem sendo comunicado". Sem isso a interação inexiste.

A escola, que deveria ser um local de acolhimento, atendendo às necessidades específicas de formação do estudante, está distante quando ele precisa de ajuda. A essa questão mais de metade dos estudantes não responde, pois não sabe ou não acredita que possa obter ajuda. Quando a função da escola não se limita ao conhecimento específico da área de formação, a instituição procura estimular o desenvolvimento pessoal e profissional do estudante, sua inserção no mundo, participando do cuidado ao estudante (Sacristan, 2001).

A pesquisa nos portais mostra a preocupação institucional com o tema consumo de drogas pelo estudante universitário, pois mais de metade das IES apresentam eventos ou atividades relacionadas, mas apenas 27 confirmam a existência de projetos no questionário. O número é preocupante quando se 
considera a dimensão local, nacional e mundial do problema. É necessária uma maior participação das instituições, promovendo não apenas ações pontuais, mas processos contínuos de enfrentamento e suporte para seu estudante, através de projetos que, na prática, mudem a realidade do consumo de drogas entre os estudantes universitários. Se, na verdade, não estou no mundo para simplesmente a ele me adaptar, mas para transformá-lo; se não é possível mudá-lo sem um certo sonho ou projeto de mundo, devo usar toda possibilidade que tenha para não apenas falar de minha utopia, mas participar de práticas com ela coerentes (Paulo Freire, 2000).

Através da análise das informações obtidas nos questionários, desenhamos um panorama vasto com propostas que incluem pequenos projetos (informação ou eventos pontuais) até programas amplos que transitam pelos 3 eixos fundantes do ensino superior (ensino, pesquisa e extensão). Passamos por programas que focam apenas o aluno e outros que entendem que o meio no qual está inserida a IES é determinante para o desenvolvimento escolar e essas instituições estendem seus projetos à comunidade externa, entendendo que o problema do consumo de drogas pelo estudante só poderá ser combatido com o enfrentamento conjunto da sociedade na qual o aluno transita. Freire (1992) afirma que a liberdade do indivíduo (no presente estudo prevenção ao consumo de drogas) só tem significado quando se alcança também a transformação da sociedade: o sonho se faz de uma necessidade, uma precisão.

Trabalhos que estudam o consumo de drogas pelo estudante universitário e a diminuição do desempenho escolar indicam que existe uma relação entre os dois fatores, mas são necessários mais estudos para estabelecer essa relação com nitidez (Gill, 2002). Esse fato ressalta a importância da existência dos núcleos de apoio psicopedagógico que atendem, orientam e encaminham os alunos com problemas pedagógicos e pessoais, e deveriam ser presentes em todas as instituições.

Devemos ressaltar a importância de estudo de caso em relação aos programas existentes, uma vez que existe uma grande variedade de propostas, e a avaliação desses diferentes projetos é um desafio que se impõe. Uma primeira 
visão desses programas mostra essa multiplicidade de abordagens e a necessidade de avaliação interna e externa de cada um deles. Nesse sentido, o Departamento de Educação dos Estados Unidos vem promovendo avaliações e financiamento dos melhores e mais efetivos programas de suas universidades desde 1999.

Para que um programa de prevenção tenha bons resultados, há necessidade de que atue em múltiplas frentes e de uma participação ampliada do corpo diretivo, estudantes, docentes, funcionários e membros da comunidade. A adesão de todos esses setores dá legitimidade e efetividade ao processo.

Entre as estratégias sugeridas pelo Office of Safe and Dug-free (US Department of Education) na publicação Alcohol and other drug prevention on colleges campuses: model programs, podem-se destacar: atividades extracurriculares que não incluam álcool e outras drogas; aumento do padrão acadêmico (mais tempo de estudo extraclasse) e maior contato com os professores; biblioteca e instalações de lazer abertas por mais tempo; limitação da disponibilidade do álcool e outras drogas dentro do campus e proximidades; eliminação do álcool nos programas de atletismo (inclusive a propaganda e o patrocínio); restrição de promoções de álcool e propaganda no campus e em publicações do campus e alojamentos; acompanhamento para garantir a conformidade com as políticas e legislações (municipais, estaduais e federais) sobre álcool e outras drogas; disciplinamento de reincidentes e daqueles que estão envolvidos em comportamentos inaceitáveis associados ao uso de substâncias; notificação dos pais quando os alunos se envolvem em violações graves ou reiteradas das políticas ou leis de álcool ou outras drogas; lançamento de uma campanha de mídia para informar os estudantes sobre a quantidade real de consumo no campus; encorajamento da segurança do campus para trabalhar em parceria com a polícia local; formação de parcerias com a comunidade. Os programas apresentados cumprem parcialmente esses requisitos. É importante assinalar que alguns dos programas apresentados pelas IES para este estudo não são voltados para o estudante - ele participa como qualquer usuário da comunidade externa. 
As estratégias mencionadas não devem ser aplicadas como um padrão, mas ser elaboradas e adaptadas à realidade de cada instituição em uma construção coletiva, de forma abrangente e com diferentes olhares que desenhem ações de longa duração em múltiplos segmentos e com uma avaliação e divulgação bem planejadas.

Segundo Dejong (2007), são quatro as dimensões que devem ser alteradas para que os programas de prevenção sejam efetivos: 1. desenvolvimento de conhecimentos, habilidades, atitudes e intenções comportamentais; 2. eliminação ou modificação de fatores ambientais que contribuam para o problema; 3. estratégias de proteção à saúde (consequências a curto prazo) e 4. Intervenção e tratamento de alunos que apresentem indícios do uso abusivo, ou já diagnosticados. Essas dimensões foram parcialmente consideradas na elaboração dos diferentes programas analisados. Os programas não descrevem as ações e as estratégias planejadas para mudança do ambiente no campus, embora existam estratégias de promoção à saúde e intervenção no sentido de tratar ou encaminhar para tratamento estudantes com dificuldades em relação ao consumo de drogas.

A divulgação dos programas oferecidos deve melhorar, incluindo disponibilização do programa nos sites institucionais e as políticas adotadas nos campi em relação ao consumo de álcool, tabaco e outras drogas, bem como as ações planejadas, as regras $\mathrm{e}$ as restrições quanto ao uso, informando e conscientizando o estudante sobre as consequências de violar essas políticas.

A maior dificuldade encontrada é em relação à avaliação dos programas existentes que, se ocorrem, não fazem parte da maioria dos projetos, que não apresentam estratégias ou mecanismos previamente planejados em relação ao cumprimento dos objetivos propostos, muitas vezes não tendo sido elaborados a partir de um diagnóstico local com reconhecimento dos problemas internos da instituição.

O projeto institucional deve ter ações planejadas e efetivadas que mobilizem os estudantes, os professores, os funcionários e os gestores. Apenas a disponibilidade às mudanças, que ocorrem através da percepção e da participação nos processos que alterem a maneira de ser e agir do indivíduo, da coletividade e do ambiente, pode levar a uma redução no consumo de drogas, porque o 
verdadeiro enfrentamento do problema no meio universitário depende do conhecimento, da decisão, da mudança de atitude e compromisso. Lembrando Paulo Freire (1996):

Seria exagero idealista afirmar que a assunção, por exemplo, de que parar de fumar ameaça a minha vida já significa deixar de fumar. Mas deixar de fumar passa, em algum sentido, pela assunção do risco que corro ao fumar. Por outro lado, a assunção se vai fazendo cada vez mais assunção na medida em que ela engendra novas opções, por isso mesmo que ela provoca ruptura, decisão e novos compromissos. Quando assumo o mal ou os males que o cigarro pode me causar, movo-me no sentido de evitar males. Decido, rompo, opto. Mas é na prática de não fumar que a assunção do risco que corro por fumar se concretiza materialmente.

Nesse sentido, um programa do enfrentamento do consumo de drogas objetivando prevenir, orientar ou tratar o estudante se faz com a elaboração de projetos institucionais que se inspirem em programas avaliados como efetivos, norteados por manuais elaborados com essa finalidade, mas norteados pelas características locais dos estudantes e da instituição. O incentivo por órgãos públicos que atuam na área de políticas sobre drogas, direcionado ao ensino superior, com avaliação e financiamento dos melhores programas, além da divulgação dos projetos que possam ser tomados como modelo, é um caminho para o estímulo às instituições na elaboração de mais e melhores projetos. Vale ressaltar que, embora as orientações para elaboração dos programas sejam vitais, o aspecto mais importante é a adaptação local das orientações e dos modelos, a partir do diagnóstico situacional da IES, que tornará o projeto eficaz.

Desse modo, a partir desta primeira pesquisa nacional que mapeou as Instituições de Ensino Superior que respondem ao problema elaborando um projeto de prevenção, orientação ou assistência, percebe-se que esse número é ainda pequeno. $O$ desenho desses projetos necessita de melhorias, focando incisivamente na avaliação. Assim, surge a necessidade de não apenas apoiar os projetos existentes visando a orientação, a avaliação e a ampliação, mas de também, ao mesmo tempo, elaborar políticas públicas dirigidas às IES que estimulem a implementação de outros programas. 
Os dados observados nesta pesquisa podem contribuir para a criação e a avaliação de políticas institucionais voltadas a prevenção, orientação ou assistência, em relação ao uso indevido de álcool, tabaco e outras drogas pelos universitários.

\section{Concluindo:}

Dos alunos pesquisados, 58\% conhecem a existência de ações de apoio à saúde. Poucos (10\%) entre estes que têm conhecimento utilizam os serviços disponíveis e apenas $23 \%$ deles afirmam ter recebido informações sobre 0 consumo de drogas e suas consequências.

Na percepção dos alunos, 59\% não sabem ou não acreditam ser possível encontrar ajuda em relação ao consumo indevido de drogas em suas instituições, embora sejam responsáveis pela formação do aluno como profissional e seu desenvolvimento pessoal e, portanto, local onde se espera deveria haver programas de apoio e orientação ao corpo discente.

Os sites institucionais mostram a existência de eventos cuja temática é o consumo de drogas e sua prevenção em 53\% das instituições pesquisadas, mas é necessário mais do que ações pontuais para que possa ser configurado um projeto institucional de enfrentamento e prevenção desse consumo. Em $20 \%$ das IES pesquisadas foram encontrados no site projetos institucionais com essa temática.

Apenas 32,9\% das IES que responderam ao questionário afirmaram ter projetos/programas referentes ao tema drogas (nas áreas de ensino, prevenção e assistência). As respostas ao questionário mostram projetos que apresentam grande variedade de ações e abrangência, desde ações limitadas a poucos eventos e focada apenas na divulgação de informações, até projetos amplos, que envolvem toda a instituição, nas áreas de ensino, pesquisa e extensão,

Os projetos de que os alunos podem participar são diversificados em relação ao público abrangido - vão desde apenas alunos até comunidade acadêmica e/ou comunidade externa, e incluem prevenção, orientação e/ou assistência ao usuário.

Os projetos enviados e analisados confirmam o observado nas respostas ao questionário sobre a diversidade e a abrangência dos programas, mostrando uma 
preocupação com a prevenção presente em todos os programas, com ações e metodologias diversificadas, incluindo produção de material didático. Mostram ainda atuações nas áreas de assistência e acompanhamento, além de formação de multiplicadores e capacitação. A avaliação dos projetos não aparece no planejamento de 13 entre os 18 programas analisados.

Os resultados mostram que, apesar de os estudantes universitários serem uma população de risco para o uso de álcool, tabaco e outras drogas, o investimento das IES na prevenção e assistência aos estudantes ainda é insuficiente. 


\section{Anexo A}

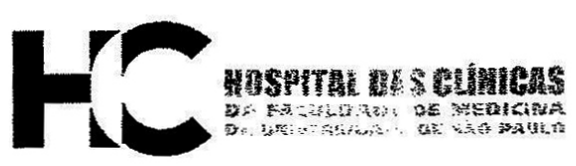

\section{APROVAÇÃO}

A Comissão de Ética para Análise de Projetos de Pesquisa CAPPesq da Diretoria Clínica do Hospital das Clínicas e da Faculdade de Medicina da Universidade de São Paulo, em sessão de 06/08/2008, APROVOU o Protocolo de Pesquisa $n^{\circ}$ 0378/08, intitulado: "I LEVANTAMENTO NACIONAL SOBRE O USO DE ÁlCOOL, TABACO E OUTRAS DROGAS ENTRE UNIVERSITÁRIOS DAS 27 CAPITAIS BRASILEIRAS" apresentado pelo Departamento de PSIQUIATRIA, inclusive o Termo de Consentimento Livre e Esclarecido.

Cabe ao pesquisador elaborar e apresentar à CAPPesq, os relatórios parciais e final sobre a pesquisa (Resolução do Conselho Nacional de Saúde no 196, de 10/10/1996, inciso IX.2, letra "C").

Pesquisador (a) Responsável: Arthur Guerra de Andrade

Pesquisador (a) Executante: Arthur Guerra de Andrade

CAPPesq, 12 de Agosto de 2008

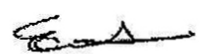

Prof. Dr. Eduardo Massad Presidente da Comissão de Ética para Análise de Projetos de Pesquisa

. Recebuld:13 108 108, as $/ 1$ ho 2

Departamento de Psiguratia de FMUSP

Comissão de Ética para Análise de Projetos de Pesquisa do HCFMUSP e da FMUSP Diretoria Clinica do Hospital das Clínicas da Faculdade de Medicina da Universidade de São Paulo Rua Ovídio Pires de Campos, 255, $5^{\circ}$ andar - CEP 05403010 - São Paulo - SP Fone: 01130696442 Fax: 01130696492 e-mail: cappesq@hcnet.usp.br/secretariacappesq2@hcnet.usp.br 


\section{Anexo B}

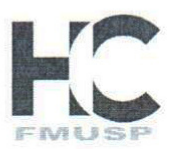

Hospital das Clínicas da FMUSP

Comissão de Ética para Análise de Projetos de Pesquisa

CAPPesq

Ao

Departamento de Psiquiatria

O Coordenador da Comissão de Ética para Análise de Projetos de Pesquisa-CAPPesq da Diretoria Clínica do Hospital das Clínicas da Faculdade de Medicina da Universidade de São Paulo, APROVOU ad-referendum em 06.03.12 a execução do subprojeto intitulado: "POLITICAS INSTITUCIONAIS: COMO O TEMA DROGAS É ABORDADO PELOS PROJETOS PEDAGÓGICOS", que será tese de doutorado da aluna MARCIA RODRIGUES GARCIA TAMOSAUSKAS, tendo como orientador O PROF. DR. MILTON DE ARRUDA MARTINS, pelo Programa de Pós-graduação Ciências Medicas do Departamento de Clinica Medica.

O referido projeto faz parte do Protocolo de Pesquisa $\mathrm{n}^{\circ}$ 0378/08, intitulado "I LEVANTAMENTO NACIONAL SOBRE O USO DE ÁlCOOL, TABACO E OUTRAS DROGAS ENTRE UNIVERSITÁRIOS DAS 27 CAPITAIS BRASILEIRAS", aprovado por esta CAPPesq em 06.08.08, que tem como Pesquisador Responsável Prof. Dr. Arthur Guerra de Andrade

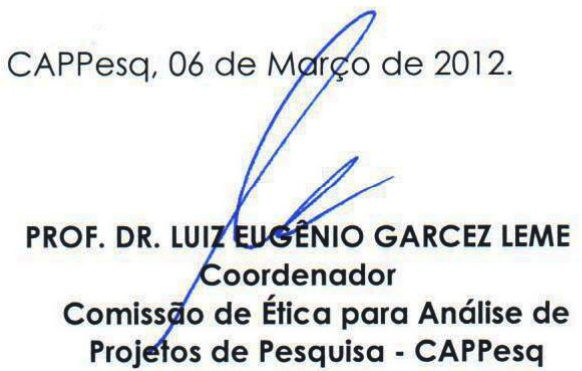




\section{Anexo C}

\section{SEÇÃO J - POLÍTICAS INSTITUCIONAIS}

Q73. A IES onde você estuda oferece algum tipo de programa de atendimento de saúde aos alunos? (CIRCULAR APENAS UMA RESPOSTA)

\begin{tabular}{|l|l|}
\hline Não & 1 \\
\hline Sim & 2 \\
\hline
\end{tabular}

Q74. Em caso afirmativo, você faz uso desse serviço? (CIRCULAR APENAS UMA RESPOSTA)

\begin{tabular}{|l|c|}
\hline Não & 1 \\
\hline Sim & 2 \\
\hline
\end{tabular}

Q75. Nos últimos 12 meses, em sua IES, você recebeu alguma informação sobre o uso de álcool e outras drogas e seu impacto sobre a saúde? (CIRCULAR APENAS UMA RESPOSTA)

\begin{tabular}{|l|c|}
\hline Não & 1 \\
\hline Sim & 2 \\
\hline
\end{tabular}

Q76. Em caso positivo, como essas informações têm sido ministradas?

(ASSINALE TODAS AS ALTERNATIVAS QUE SE APLICAM)

\begin{tabular}{|l|l|}
\hline Através de aulas, palestras, reuniões ou workshops & 1 \\
\hline Através de cartas, comunicados ou panfletos & 2 \\
\hline Através de pôsteres informativos & 3 \\
\hline Através da leitura de artigos e informativos nos jornais dos estudantes & 4 \\
\hline Através de um curso especial sobre álcool e drogas & 5 \\
\hline
\end{tabular}

Q77. Em sua opinião, em sua IES, quanto é possível que um estudante encontre, da parte de um conselho, professores ou outro adulto, ajuda para reduzir ou parar o consumo de álcool ou outras drogas? (CIRCULAR APENAS UMA RESPOSTA)

\begin{tabular}{|l|c|}
\hline Muito possível & 1 \\
\hline Possível & 2 \\
\hline Não é possível & 3 \\
\hline Não sei & 4 \\
\hline
\end{tabular}




\section{Anexo D}

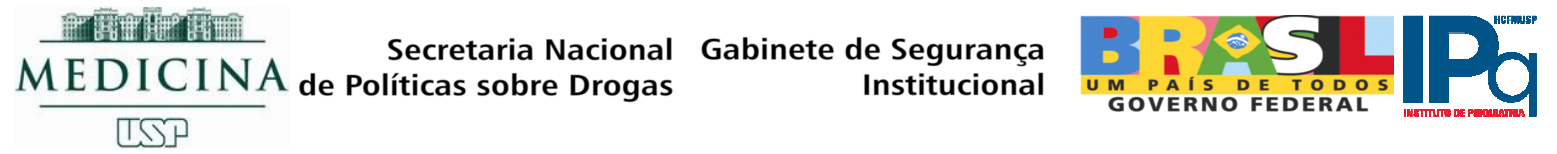

Como parte integrante do "I levantamento nacional sobre o uso de álcool, tabaco e outras drogas entre universitários das 27 capitais brasileiras", pedimos a gentileza de responderem esse formulário. Uma vez respondido, solicitamos que o entreguem na recepção.

Nome da Instituição:

Sigla: Estado:

1. Em sua instituição, existe algum projeto ou programa de prevenção, orientação ou assistência do uso de álcool, tabaco e outras drogas, direcionados ao corpo discente?

( ) SIM ( ) NÃO: em caso negativo, não é necessário continuar respondendo.

Se a resposta for positiva, por favor, responda:

2. Esse programa faz parte do Plano de Desenvolvimento Institucional (PDI)?

( ) $\operatorname{SIM}($ ) NÃO

3. . Esse programa compõe o Projeto Pedagógico da instituição (PPI)?

( ) $\operatorname{SIM}($ ) NÃO

4. Esse é um programa de extensão da IES?

( ) $\operatorname{SIM}($ ) NÃO

5. Esse programa é voltado única e exclusivamente ao corpo discente ou engloba outras populações dentro da IES

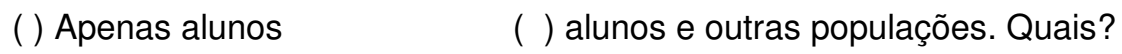

6. Como os alunos têm acesso ao programa?

7. Como esse programa é divulgado dentro da IES?

8. O programa é divulgado para outro publico? De que maneira?

8. Em que departamento ou setor se insere esse programa?

9.Qual o departamento, grupo ou pessoa é responsável por esse programa? Como entrar em contato com o(s) responsável(eis) pelo programa? 


\section{Anexo E}

\section{hOSPItAl das clínICAS da faculdade de medicina da UNIVERSIDADE DE SÃO PAULO-HCFMUSP}

\section{DADOS DE IDENTIFICAÇÃO DO SUJEITO DA PESQUISA}

1. NOME:

DOCUMENTO DE IDENTIDADE № : SEXO : .M $\square \quad F$

DATA NASCIMENTO:

ENDEREÇO APTO:

BAIRRO:

CEP:

TELEFONE:

DDD

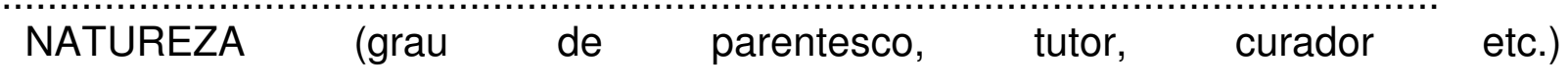

DOCUMENTO DE IDENTIDADE : SEXO: $M \square \quad F \square$ DATA NASCIMENTO. ENDEREÇO:

\section{DADOS SOBRE A PESQUISA}

1. TÍTULO DO PROTOCOLO DE PESQUISA: I Levantamento Nacional sobre o Uso de Álcool, Tabaco e outras Drogas entre Universitários das 27 capitais brasileiras.

2. PESQUISADOR: Arthur Guerra de Andrade 
CARGO/FUNÇÃO: Professor Associado do Departamento de Psiquiatria da Faculdade de Medicina da Universidade de São Paulo - HCFMUSP

INSCRIÇÃO CONSELHO REGIONAL № : 33.807

UNIDADE DO HCFMUSP: Instituto de Psiquiatria

\section{AVALIAÇÃO DO RISCO DA PESQUISA:}

$\begin{array}{lll}\text { RISCO MÍNIMO } & X & \text { RISCO MÉDIO } \\ \text { RISCO BAIXO } & \square & \text { RISCO MAIOR }\end{array}$

4.DURAÇÃO DA PESQUISA : 24 meses

\section{1 - Desenho do estudo e objetivo(s):}

O objetivo deste estudo é realizar o primeiro levantamento nacional sobre a prevalência e o padrão de uso de álcool, tabaco e outras drogas entre os estudantes universitários das redes pública e privada de ensino, das 27 capitais brasileiras. Trata-se de um estudo epidemiológico e transversal, com seleção de amostra representativa através da técnica de amostragem por conglomerados e estratificação. A princípio, propõe-se o estudo de 31.332 universitários, de 1.045 turmas de graduação, distribuídas por, pelo menos, duas Instituições de Ensino Superior (IES) por capital (uma IES pública e outra IES privada). Para a compreensão detalhada e aprofundada desse comportamento entre os universitários brasileiros, a presente proposta foi dividida em nove sub-projetos, de objetivos e equipe específicos.

\section{2 - Descrição dos procedimentos que serão realizados, com seus propósitos e identificação dos que forem experimentais e não-rotineiros.}

Para atingir o propósito acima mencionado, em sua turma serão distribuídos três questionários, de auto-aplicação, constituídos predominantemente por questões fechadas e na forma de alternativas, aos quais você será convidado a responder. O primeiro questionário nos auxiliará a compreender os mais variados tópicos de sua vida, a citar: (a) dados sócio demográficos; (b) breve caracterização de seu ambiente familiar; (c) caracterização de seu curso universitário e vida acadêmica; (d) uso pessoal (na vida, nos últimos 12 meses e nos últimos 30 dias) de álcool, tabaco e outras drogas e outros comportamentos e, finalmente, (e) avaliação de sua opinião sobre os riscos associados ao uso experimental e regular de álcool, tabaco e outras drogas.

O segundo questionário, denominado Inventário de Depressão de Beck (2 ${ }^{\mathrm{a}}$ versão), é um instrumento de auto-aplicação, de 21 questões, com afirmações sobre como você tem se sentido nos últimos 15 dias.

Finalmente, a Escala Breve K-10 é outro instrumento de auto-aplicação, constituído por 10 questões, que será adotado para o rastreamento de possível sofrimento psicológico. 
Para o preenchimento dos três instrumentos de pesquisa você necessitará de cerca de 50 minutos.

\section{3 - Relação dos procedimentos rotineiros e como são realizados (coleta de sangue por punção periférica da veia do antebraço; exames radiológicos).}

Esses procedimentos não se aplicam à presente proposta.

\section{4 - Descrição dos desconfortos e riscos esperados nos procedimentos dos itens 2 e 3.}

Os instrumentos de pesquisa adotados coletarão informações de sua vida pessoal, logo, não existem respostas certas ou erradas. Todas as informações que você puder nos fornecer serão de muito valor. As respostas são anônimas e confidenciais, ou seja, não há campos para o preenchimento de dados pessoais (como nome, endereço, telefone residencial, telefone celular ou email). Assim, para garantir sua segurança e conforto, você terá a oportunidade de escolher o questionário a ser respondido e após completá-lo, você deverá inseri-lo dentro de uma urna, localizada dentro de sua sala de aula. Uma vez coletados, os questionários serão organizados e misturados aos de estudantes de outras Instituições de Ensino Superior (IES) brasileiras. Logo, suas informações serão analisadas em conjunto com as de outros universitários.

De forma geral, a análise dos dados será realizada conforme a região administrativa a que sua IES pertença, de tal forma que as variáveis referentes à IES e à unidade federativa (estado) serão desconsideradas. Assim, a chance de reconhecimento de suas respostas será nula, não lhe oferecendo nenhum tipo de risco.

É importante ressaltar que a sua participação é voluntária, cabendo-lhe o direito de não consenti-la. Caso opte por responder os instrumentos de pesquisa, pedimos que preencha todas as questões, assim como o faça com a maior sinceridade possível. Além disso, caso opte por respondê-los, você tem o direito de desistir a qualquer momento, sem que lhe seja acarretado qualquer tipo de problema.

\section{5 - Benefícios para o participante.}

Não há benefício direto ao participante. Trata-se de uma oportunidade única para que você possa contribuir ao melhor entendimento sobre a situação do uso de álcool, tabaco e outras drogas e outros comportamentos entre os universitários brasileiros, estudo inédito no Brasil. Mais que possibilitar a compreensão do fenômeno do uso de drogas entre os universitários brasileiros, essa é uma oportunidade para o desenvolvimento de programas de prevenção e políticas públicas adequadas, a serem destinadas ao consumo de substâncias psicotrópicas entre os estudantes universitários. 


\section{6 - Relação de procedimentos alternativos que possam ser vantajosos, pelos quais o estudante possa optar.}

A presente proposta não engloba procedimentos alternativos. No caso de negação de participação, você não poderá ser substituído, pois procedimentos estatísticos rigorosos foram utilizados para selecionar sua turma de graduação, na qual todos os estudantes foram selecionados a participar. Porém, você tem o direito de negar ou desistir de participar a qualquer momento.

\section{7 - Garantia de acesso.}

Em qualquer etapa do estudo, você terá acesso aos profissionais responsáveis pela pesquisa para esclarecimento de eventuais dúvidas. O principal investigador é o Dr Arthur Guerra de Andrade que pode ser encontrado no Instituto de Psiquiatria (IPq), da Faculdade de Medicina da Universidade de São Paulo (HCFMUSP), localizado à Rua Ovídio Pires de Campos, 785, São Paulo, SP (email: aandrade@usp.br; telefone: (11) 3842-0404).

Se você tiver alguma consideração ou dúvida sobre a ética da pesquisa, entre em contato com o Comitê de Ética em Pesquisa (CEP) - Rua Ovídio Pires de Campos, 225 - 5ำ andar - Tel: 3069-6442 (ramais 16, 17, 18 ou 20); FAX: 3069-6442 (ramal 26)(e-mail: cappesq@hcnet.usp.br)

8 - É garantida a liberdade da retirada de consentimento a qualquer momento e deixar de participar do estudo, sem qualquer prejuízo à continuidade de seu tratamento na Instituição

9 - Direito de confidencialidade: As informações obtidas serão analisadas em conjunto com outros universitários, não sendo divulgado a identificação de nenhum estudante;

10 - Direito de ser mantido atualizado sobre os resultados parciais das pesquisas, quando em estudos abertos, ou de resultados que sejam do conhecimento dos pesquisadores;

11 - Despesas e compensações: não há despesas pessoais para o participante em qualquer fase do estudo, incluindo exames e consultas. Também não há compensação financeira relacionada à sua participação. Se existir qualquer despesa adicional, ela será absorvida pelo orçamento da pesquisa. 
12 - Em caso de dano pessoal, diretamente causado pelos procedimentos ou tratamentos propostos neste estudo (nexo causal comprovado), o participante tem direito a tratamento médico na Instituição, bem como a indenizações legalmente estabelecidas.

13 - Compromisso do pesquisador de utilizar os dados e o material coletado somente para esta pesquisa.

Acredito ter sido suficientemente informado a respeito das informações que li ou que foram lidas para mim, descrevendo o estudo "I Levantamento Nacional sobre o Uso de Álcool, Tabaco e outras Drogas entre Universitários das 27 capitais brasileiras."

Eu discuti com o Dr Arthur Guerra de Andrade sobre a minha decisão em participar nesse estudo. Ficaram claros para mim quais são os propósitos do estudo, os procedimentos a serem realizados, seus desconfortos e riscos, as garantias de confidencialidade e de esclarecimentos permanentes. Ficou claro também que minha participação é isenta de despesas e que tenho garantia do acesso a tratamento hospitalar quando necessário. Concordo voluntariamente em participar deste estudo e poderei retirar o meu consentimento a qualquer momento, antes ou durante o mesmo, sem penalidades ou prejuízo ou perda de qualquer benefício que eu possa ter adquirido, ou no meu atendimento neste Serviço.

Assinatura do paciente/representante legal Data $1 \quad 1$

Assinatura da testemunha

para casos de pacientes menores de 18 anos, analfabetos, semi-analfabetos ou portadores de deficiência auditiva ou visual.

(Somente para o responsável do projeto)

Declaro que obtive de forma apropriada e voluntária o Consentimento Livre e Esclarecido deste paciente ou representante legal para a participação neste estudo.

Assinatura do responsável pelo estudo

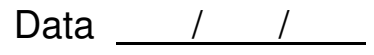


Abramovay M, Castro MG. Drogas nas escolas. Brasília: Unesco, 2005. [acesso em:2012 ago 23]. Disponível em: http://unesdoc.unesco.org/images/0013/001393/139387por.pdf.

Akmatov MK, Mikolajczyk RT, Meier S, Krämer A. Alcohol comsumption among university students in nortyh Rhine-Westphalia, Germany - results from a multicenter cross-sectional study. J AM Coll Health. 2011; 59(7):620-6.

Akvardar Y, Demiral Y, Ergör G, Ergör A, Bilici M, Özer ÖA. Substance use in a sample of Turkish medical students. Drug Alcohol Depend. 2003 Nov 24; 72(2):117-21.

Alfani AC, Castro A, Chade MC, Costa LFO, Del Nero TO, Favero AC, Greghl V, Tribist AL, Hübner CK. Comparação do uso de drogas entre acadêmicos do curso de medicina da Pontifícia Universidade Católica de São Paulo. Rev. Fac. Ciênc. Med. Sorocaba. 2004;6(1):7-14.

Alves ACS, Constantino KRS, Martins FJP, Rodrigues L, Silveira MJL. Uso de drogas lícitas e ilícitas entre os estudantes da universidade Braz Cubas. Biofar, Rev. Biol. Farm. Campina Grande/PB, 2013 jun-ago; 9(2):98-106.

Alves AL, Durães SW, Ferreira LR, Fiorini CM, Fiorini JE, Geraldini AMV Nascimento LC, Santos RLD, Ortiz CF. Use of licit and illicit drugs at the university of Alfenas. Rev. Hosp. Clin. Fac. Med. São Paulo. 2003 Jul-Aug; 58(4):199-206.

Amiri ZM, Shakib AJ, Moosavi AK. Prevalence and risk factors of ecstasy use among college students in Astara, Islamic Republic of Iran. East Mediterr Health J. 2009 Sep-Oct;15(5):1192-200.

Anais do Encontro Nacional do Fórum de Pró-Reitores de Extensão das Universidades Públicas. 1993; Cuiabá [Internet].VII Avaliação da extensão no contexto da autonomia universitária, Cuiabá: Editora UFMT [acesso em 2012 nov 28]; 1993.

Disponívelem:http://www.unifalmg.edu.br/extensao/files/file/colecao_extensao_ univeristaria/colecao_extensao_universitaria_3_avaliacao.pdf.

Anderson P, Chisholm D, Fuhr DC. Effectiveness and cost-effectiveness of policies and programmes to reduce the harm caused by alcohol. Lancet. 2009 Jun 27;373(9682):2234-46.

Andrade AG, Bassit AZ, Mesquita AM, Fukushima JT, Gonçalves EL. Prevalência do uso de drogas entre alunos da Faculdade de Medicina da Universidade de São Paulo (1991-93). Rev. ABP-APAL. 1995 abr-jun; 17(2): 41-6.

Andrade AG, Duarte PCAV, Oliveira LG, organizadores. I Levantamento nacional sobre o uso de álcool, tabaco e outras drogas entre universitários das 27 capitais brasileiras.Brasília: Secretaria Nacional de Políticas sobre Drogas;2010. 284 p. 
Andrade LHSG, Silveira CM, Siu ER, Andreuccetti G, Oliveira LG, Andrade AG. Padrões de consumo do álcool entre universitários. In: Andrade AG, Duarte PCAV, Oliveira LG, organizadores. I Levantamento nacional sobre o uso de álcool, tabaco e outras drogas entre universitários das 27 capitais brasileiras. Brasília: Secretaria Nacional de Políticas sobre Drogas;2010. p.83-100.

Andrade, AG, Queiróz, S, Villaboim, RCM. Uso de álcool e drogas entre alunos de graduação da Universidade de São Paulo. Revista ABP-

APAL.1997b;19(2):53-9.

André, MED. O projeto pedagógico como suporte para novas formas de avaliação. In: Castro AD, Carvalho AMP, organizadores. Ensinar a ensinar. São Paulo: Thomson Pioneira; 2001.

Araldi JC, Ghizoni AC, Njaine K, Oliveira MC. Representações sociais de professores sobre o uso abusivo de álcool e outras drogas na adolescência: repercussões nas ações de prevenção na escola. Interface - Comunic.Saúde Educ. 2012 jan-mar; 16(40):135-48.

Assanangkornchai S, Mukthong A, Intanont T. Prevalence and patterns of alcohol consumption and health-risk behaviors among high school students in Thailand. Alcohol. Clin. Exp. Res. 2009 Dec; 33(12):2037-46.

BachmanJG, O'Malley PM, Schulenberg JEJohnston LD, Bryant AL, Merline AC. The decline of substance use in young adulthood: Changes in social activities, roles, and beliefs. Mahwah:Lawrence Erlbaum Associates;2002.

Bachman JG, Wadsworth KN, O'Malley PM, Johnston L D, Schulenberg JE. Smoking, drinking, and drug use in young adulthood: The impacts of new freedoms and new responsibilities. Mahwah:Lawrence Erlbaum Associates; 1997.

Bardin L. Análise de conteúdo.Trad. Luís Antero Reto e Augusto Pinheiro.Lisboa:Edições 70;2002.

Barria ACR, Queiroz S, Nicastri S, Andrade AG. Comportamento do universitário da área de biológicas da Universidade de São Paulo, em relação ao uso de drogas. Rev. Psiquiatr. Clín. 2000 jul-ago; 27(4):215-24.

Baskin M, Corey K, Faden VB. Anevalution of college online alcohol-policy information: 2007 compared with 2002. J. Stud. Alcohol Drugs. Suppl. 2009 Jul; (16):28-33.

Bastos SECO. Levantamento do uso de drogas e álcool em estudantes de medicina da Universidade Federal de Sergipe. [dissertação]. Ribeirão Preto: Faculdade de Medicina de Ribeirão Preto/USP;1999.

Blume TW. A social role negotiation approach to campus prevention of alcohol and other drug problems. In: Designing alcohol and other drug prevention programs in higher education. [Washington, D.C.]:US Department of Education; 1997. 
Botti NCL, Lima AFD, Simões WMB. Uso de substâncias psicoativas entre acadêmicos de enfermagem da Universidade Católica de Minas Gerais. SMAD [internet]. 2010 [acesso em 2012 set 24]; 6(1):1-16.Disponível em: http://pepsic.bvsalud.org/scielo.php?script=sci_arttext\&pid=S1806$69762010000100013 \&$ lng=pt\&nrm=iso.

Botvin GT, Griffin KW. Drug abuse prevention curricula in shools. In: Sloboda Z, Bukoski WJ.Handbook of drug abuse prevention: theory, science and practice. New York:L Klumer Academic/Plenum Publishers, 2002

Boutinet J. Antropologia do projeto. 5.ed. Porto Alegre: Artmed; 2002.

Brasil.Artigo 16 do Decreto no 5.773 , de 9 de maio de 2006, atualizado em 5 de junho de 2007.Plano de desenvolvimento institucional - PDI:diretrizes para elaboração[Internet].Sistema de Acompanhamento de Processos das Instituições de Ensino Superior - SAPIEnS/MEC[acesso em 2012 ago 18]. Disponível em:http://www2.mec.gov.br/sapiens/pdi.html.

Brasil. Constituição da República Federativa do Brasil. Brasília: Senado Federal; 1988. 292 p.

Brasil. Lei no 11.892, de 29 de dezembro de 2008. Institui a Rede Federal de Educação Profissional, Científica e Tecnológica, cria os Institutos Federais de Educação, Ciência e Tecnologia, e dá outras providências. Diário Oficial [da] União da República Federativa do Brasil. 2008 dez. 30; Seção 1. p.1.

Brasil. Lei no 9.394, de 20 de dezembro de 1996. Estabelece as diretrizes e bases da educação nacional (LDB). Diário Oficial [da]República Federativa do Brasil.1996dez.;no 248. p. 27.833-27.841.

Brasil. Ministério da Educação e do Desporto. Conselho Nacional de Educação. Orientação para diretrizes dos cursos de graduação. Parecer oㅡ 776/97, 3 de dezembro de 1997. [ acesso em 2012 jun 23]. Disponível em:http://portal.mec.gov.br/cne/arquivos/pdf/1997/pces776 97.pdf.

Brasil. Presidência da República, Secretaria Nacional de Políticas sobre Drogas- SENAD. Relatório brasileiro sobre drogas/Secretaria Nacional de Políticas sobre Drogas; IME USP; DuartePCAV, Stempliuk VA, Barroso LP. Brasília: SENAD; 2009. 364 p. [acesso em 2011ago 29]. Disponível em:http://www.unisite.ms.gov.br/unisite/controle/ShowFile.php?id=100977.

Brasil. Presidência da República. Secretaria Nacional de Políticas sobre Drogas- SENAD. I Levantamento nacional sobre o uso de álcool, tabaco e outras drogas entre universitários das 27 capitais brasileiras. Andrade AG, Duarte PCAV, Oliveira LG, organizadores.Brasília:SENAD; 2010. 284 p.

Brenes LFV, Hammes MF, Solé MTV, Hein R, Ramil KAA. Drogas ilícitas entre universitários. Rev. AMRIGS. 1986 abr-jun; 30(2):140-3.

Brenes LFV, Hammes MF, Solé MTV, Hein R, Ramil, KAA. Drogas ilícitas entre universitários. Rev. AMRIGS. 1986 abr.-jun; 30(2):140-3. 
Buttura IM. Projeto político-pedagógico: concepção que define a práxis. Passo Fundo:UFP; 2005.

Canada. Public Safety. School-based drug abuse prevention: promising and successful programs. Otawa:National Crime Prevention Centre (NCPC); 2009.

Canuto MHA, Ferreira RA, Guimarães EMB. Uso e abuso de drogas ilícitas por jovens do $1^{\circ}$ ano da Universidade Federal de Goiás. Rev. Paul. Pediatr. 2006; 24(2):135-42.

Carlini CM, Carlini EA,Fonseca AM, GaldurózJCF, Moura YG, Nappo SA, Noto AR, OliveiraLG, Sanchez ZVM. II Levantamento domiciliar sobre o uso de drogas psicotrópicas no Brasil: estudo envolvendo as 108 maiores cidades do país. São Paulo:CEBRID - Centro Brasileiro de Informações sobre Drogas Psicotrópicas, Departamento de Psicobiologia, Unifesp - Universidade Federal de São Paulo; 2007. 468 p.

Carlini EA, Fonseca AM, GaldurózJCF, NotoAR. V Levantamento Nacional sobre o Consumo de Drogas Psicotrópicas entre Estudantes do Ensino Fundamental e Médio da Rede Pública de Ensino nas 27 Capitais Brasileiras 2004. São Paulo: CEBRID; 2005. 398 p.

Carlini EA, Galduróz JCF, Noto AR. IV Levantamento sobre ouso de drogas entre estudantes do $1^{\circ}$ e do $2^{\circ}$ graus em 10 capitais brasileiras. São Paulo: CEBRID; 1997.

Chiapetti N, Serbena CA. Uso de álcool, tabaco e drogas por estudantes da área de saúde de uma Universidade de Curitiba. Psicol. Reflex. Crit. [Internet]. 2007 [acesso em 2012 ago 22]; 20(2):303-13. Disponível em: http://dx.doi.org/10.1590/S0102-79722007000200017.

Cotrim BC. Drogas na escola: prevenção, tolerância e pluralidade. In: AQUINO JRG, organizador).Drogas na escola: alternativas teóricas e práticas. São Paulo:Summus; 1998.

Cotrim BC. Estratégias preventivas nas escolas. In: Seibel SD, editor. Dependência de drogas. 2.ed. São Paulo:Atheneu;2010. p.787-94.

Cunha, AG. Dicionário etimológico da língua Portuguesa. 4.ed. rev. pela nova ortografia. Rio de Janeiro: Lexicon, 2010.

DeJong W, Langford LM. A typology for campus-based alcohol prevention: moving toward environmental management strategies. J. Stud. Alcohol Suppl. 2002 Mar; (14):140-7.

DeJong W.Alcohol and other drug prevention models on College CampusesGrants 2007. [acesso em 2009 ago 6]. Disponível em: http://www.higheredcenter.org/files/product/effective-prevention.pdf.

Delors J, Mufti IA, Amagi I, Carneiro R, Chung F, Geremek B, Gorham W, Kornhauser A, Manley M, Quero MP, Savané MA, Singh K, Stavenhagen R, Suhr MW, Nanzhao Z. Educação: um tesouro a descobrir. 4.ed. Brasília:MEC; 2000. 
Drug and Alcohol Education and Prevention Team Drugscope. Drugs: guidance for further education instituitions. 2004 [acesso em 2012 out 15]. Disponível em:

http://www.drugscope.org.uk/Resources/Drugscope/Documents/PDF/Educatio n\%20and\%20Prevention/guidancefe.pdf.

Fernández S, Jané M, NebotM. Evaluación de la efectividad de los programas escolares de prevención del consume de tabaco, alcohol Y cannabis: ¿Qué nos dicen los meta-análisis? Rev. Esp. Salud Publica. 2002 May-Jun; 76(3): 175-87.

Fórum de Pró-Reitores de Extensão das Universidades Públicas Brasileiras. 2012;Manaus:Política Nacional de Extensão Universitária; 2012.

Freire P. A escola. Rizoma freireano [Internet]. 2010 [acesso em 2013 jun 18]; (8).Disponível em: http://www.rizoma-freireano.org/index.php/a-escola-paulofreire.

Freire P. Pedagogia da autonomia. São Paulo:Terra e Paz, 1996. (Leitura.)

Freire P. Pedagogia da esperança: um encontro com a pedagogia do oprimido. Rio de Janeiro:Terra e Paz; 1992.

Freire P. Pedagogia do oprimido. 32.ed. Rio de Janeiro:Terra e Paz; 2002.

Freire, P. Pedagogia da indignação: cartas pedagógicas e outros escritos. São Paulo: Editora Unesp; 2000.

Gadotti M. Perspectivas atuais da educação. Porto Alegre: Artes Médicas, 2000

Gill JS. Reported levels of alcohol consumption and binge drinking within the UK undergraduate student population over the last 25 years. Alcohol Alcohol. 2002 Mar-Apr; 37(2):109-20.

Golafshani N.Understanding reliability and validity in qualitative research. The Qualitative Report. 2003 Dec; 8(4):597-606.

Goštautas A, Povilaitis R, Pilkauskienè I, Jakušovaitè I, Statkevičienẻ S. Prevalence of the use of psychoactive substances among students during 2005-2006. Medicina (Kaunas). 2009; 45(7):522-9.

Horta RL, Horta BL, Horta CL. Uso de drogas e sofrimento psíquico numa universidade do Sul do Brasil. Psicol. rev. (Belo Horizonte) [Internet]. 2012[acesso em 2012 jun 17]; 18(2):264-76. Disponível em: http://dx.doi.org/10.5752/P.1678-9563.2012v18n2p264.

Houaiss A, Villar M S \& Franco F M M. Dicionário Houaiss da língua portuguesa. Rio de Janeiro: Objetiva; 2009.

INEP - Instituto Nacional de Estudos e Pesquisas Educacionais Anísio Teixeira. Resumo Técnico: censo da Educação Superior 2008 [Internet]. Brasília: INEP; 2009. [acesso em 2012 jan 28] Disponível em: http://www.inep.gov.br. 
Johnston LD, O'Malley PM, Bachman JG, Schulenberg JE. Monitoring the future national survey results on drug use, 1975-2011. Volume II: College students and adults ages 19-50. Ann Arbor: Institute for Social Research, The University of Michigan; 2012. $314 \mathrm{p}$.

Johnston, L. D., O’Malley, P. M., Bachman, J. G., Schulenberg, J. E. Monitoring the Future national results on drug use: 2012 overview, key findings on adolescent drug use. Ann Arbor: Institute for Social Research, The University of Michigan; 2013.

Jones C, Ramanau R, Cross S, Healing G. Net generation or digital natives: is there a distinct new generation entering university? Computers \& Education. 2010; 54(3):722-32.

Kalof L, Dan A, Dietzv T. Essentials of Social Research. Open University Press, Berkshire:MacGraw-Hill; 2008.

Karam EG, Maalouf WE, Ghandour LA. Alcohol use among university students in Lebanon: prevalence, trends and covariates. The IDRAC University Substance Use Monitoring Study. Medicina (Kaunas). Drug Alcohol Depend.2004 Dec;76(3):273-86.

Kerr-Correa F, Andrade AG, Bassit AZ, Boccuto NMVF. Uso de álcool e drogas por estudantes de medicina da Unesp. Rev. Bras. Psiquiatr. 1999; 21(2):95100.

Koutouzis, Michel, Atlas mondial des drogues. Paris:Observatoire Géopolitique des Drogues; 1996.

Laranjeira R, Pinsky I, Zaleski M, Caetano R, Duarte PCAV. I Levantamento nacional sobre os padrões de consumo de álcool na população brasileira. Brasília: SENAD;2007. 76 p.

Lemos, KM, Neves NMBC, Kuwano AY, Tedesqui G, Bittencourt AGV, Nevesn FBSC, Guimarães AN, Rebello A, Bacellar M, Lima MM. Uso de substâncias psicoativas entre estudantes de Medicina de Salvador (BA). Rev Psiq Clin. 2007; 34(3):118-24.

Lincoln YS, Guba EG. Controvérsias paradigmáticas, contradições e confluências emergentes. In: Denzin NK, LincolnYS. O planejamento da pesquisa qualitativa: teorias e abordagens. 2.ed. Porto alegre: Artmed; 2006. p. 169-92.

Lipkin NA, Perrymore AJ. A geração Y no trabalho: como lidar com a força de trabalho que influenciará definitivamente a cultura de sua empresa. Rio de Janeiro: Elsevier; 2010.

Lord S, Downs G, Furtaw P, Chaudhuri A, Silverstein A, Gammaitoni A, Budman S. Nonmedical use of prescription opioids and stimulants among student pharmacists. J. Am. Pharm. Assoc. 2009;49(4):519-28.

Lucas ACS, Parente RCP, Picanço NS, Conceição DA, Costa, KRC, Magalhães IRS, Siqueira JCA. Uso de psicotrópicos entre universitários da 
área da saúde da Universidade Federal do Amazonas, Brasil. Cad Saúde Pública. 2006;22(3):663-71.

Mardegan OS, Souza RS, Buaiz V, Siqueira MM. Uso de substâncias psicoativas entre estudantes de enfermagem. J. Bras. Psiquiatr. 2007; 56(4):260-6.

Mariz SR, Mariz JP, Valois MEC, Val EB.Fundamentos da prevenção ao uso indevidode drogas entre estudantes. Cad. Pesq.São Luís. 2003 jan-jul; 4(1):69-87.

McCabe SE, Schulenberg JE, Johnston LD, O'Malley PM, Bachman JG, Kloska DD. Selection and socialization effects of fraternities and sororities on U.S. college student substance use: a multi-cohort national longitudinal study. Addiction, 2005 Apr; 100(4):512-24.

Muraskin LD. Understanding evalution: the way to better prevention programs. Departament of Education, Office of Safe and Drug-Free Schools[Internet].1993 [acesso em 2009 ago 5]. Disponível em : http://www2.ed.gov/PDFDocs/handbook.pdf .

Nicastri S, Oliveira LG, Wagner GA, Andrade AG. Prevalência e padrão de uso de tabaco e outras drogas (exceto álcool): estimativa de abuso e dependência. In: Andrade AG, Duarte PCAV, Oliveira LG. I Levantamento nacional sobre o uso de álcool, tabaco e outras drogas entre universitários das 27 capitais brasileiras. Brasília: SENAD; 2010. p.53-82.

Nogueira MDP, organizador. Extensão Universitária: diretrizes conceituais e políticas. Belo Horizonte: PROEX/UFMG; 2000.

Oblinger DG, Oblinger JL. Educating the net generation. Educause [Internet]. 2005 [acesso em 2013 abr 2013].Disponível em:

http://www.educause.edu/ir/library/pdf/pub7101.pdf.

Oliveira LG, Barroso LP, Wagner GA, Ponce J, Malbergier A, Stempliuk VA, Andrade AG. Drug consumption among medical students in São Paulo, Brasil: influences of gender and academic year. Rev. Bras. Psiquiatr. 2009;31(3):22739.

Oliveira LG, Galduróz JCF, Wagner GA, Andrade AG. Uso de drogas pelos universitários brasileiros: contexto nacional e internacional. In: Andrade AG, Duarte PCAV, Oliveira LG. I Levantamento nacional sobre o uso de álcool, tabaco e outras drogas entre universitários das 27 capitais brasileiras. Brasília, DF, Brasil: SENAD; 2010. p.181-97.

Oliveira TB, Azeredo FS, Prado DS, Rezende AGA, Cunha LC, Garrote CFD. Uso de álcool, tabaco e drogas ilícitas por estudantes de farmácia da Universidade Federal de Goiás. Revista Eletrônica de Farmácia [Internet]. 2005 [acesso em 2012 maio 8]. Supl.; 2(2): 133-6. Disponível em:https://www.revistas.ufg.br/index.php/REF/article/viewFile/1995/1963. 
Paduani GF, Ferreira G, Barbosa GA, Morais JCR, Pereira JCP, Almeida MF, Prado MM, Almeida NBC, Ribeiro MA. Consumo de álcool e fumo entre os estudantes da Faculdade de Medicina da Universidade Federal de Uberlândia. Rev. bras. educ. méd. 2008 jan-mar; 32(1):66-74.

Pereira DS, Souza RS, BuaizV, Siqueira MM. Uso de substâncias psicoativas entre universitários de medicina da Universidade Federal do Espírito Santo. J. bras. psiquiatr. [Internet]. 2008[acesso em 2012 jul 14]; 57(3):188-95. Disponível em: http://www.scielo.br/pdf/jbpsiq/v57n3/06.pdf.

Peuker AC, Fogaça J, Bizarro L. Expectativas e beber problemático entre Universitários. Psicologia: Teoria e Pesquisa. 2006;22(2):193-200.

Picolotto E, Libardoni LFC, Migott AMB, Geib LTC. Prevalência e fatores associados com o consumo de substâncias psicoativas por acadêmicos de enfermagem da Universidade de Passo Fundo. Ciên Saude Colet. 2010; 15(3):645-54.

Polymerou A. Alcohol and drug prevention in Colleges and universities. A review of de literature. Mentor UK [Internet]. 2007[acesso em 2011 jun 23]. Disponivel em:

http://www.mentorfoundation.org/uploads/UK_Prevention_Colleges_and_Unive rsities.pdf.

Portugal FB, Marluce MS. Fatores associados ao uso de substâncias psicoativas entre universitários de pedagogia da universidade federal do espírito santo. Cad. Saúde Colet. 2011; 19(3):348-55.

Portugal FB, Souza, RS, Buaiz V \& Siqueira MM. Uso de drogas por estudantes de Farmácia da Universidade Federal do Espírito Santo. J. Bras. Psiquiatr. 2008; 57(2):127-32.

Queiróz S. Fatores de risco e proteção para o consumo de substâncias psicoativas entre adolescentes. In: Seibel SD, editor. Dependência de drogas. 2.ed. São Paulo: Atheneu; 2010. p.991-1005.

Rodrigues AP, Oliveira AS, Zaleski EGF, Arantes SL. Avaliação do nível de propensão para o desenvolvimento do alcoolismo entre estudantes do curso de graduação em enfermagem da universidade católica Dom Bosco SMAD, Rev. Eletrônica Saúde Mental Álcool Drog. (Ed. port.) [Internet]. 2007 [acesso em 2012 fev 10]; 3(1). Disponível em:

http://pepsic.bvsalud.org/scielo.php?script=sci_arttext\&pid=S180669762007000100005\&lng=pt\&nrm=iso.

Rondina RC, Moratelli HB, Botelho C. Tabagismo e características da personalidade em estudantes universitários. Rev Psiquiat Clin. 2001;28(2);2852.

SacristanJG. A educação obrigatória: seu sentido educativo e social. Porto Alegre: Artmed, 2001. 
Saddichha S, Khess CR. Prevalence of tobacco use among young adult males in India: a community-based epidemiological study. Am. J. Drug. Alcohol Abuse. 2010;36(1):73-7.

Saltz RF, DeJong W. Reducing alcohol problems on campus: a guide to planning and evaluation. National Institut of Health. 2002 Apr; (025011).

Salviani, D. Pedagogia histórico-crítica: primeiras aproximações. 10.ed. rev. Campinas:Autores Associados; 2008.

Sampiere RH, ColladoCF, Lucio PB. Metodologia de pesquisa.3.ed. São Paulo:MacGraw-Hill; 2006.

Sanchez ZM, Oliveira LG, Ribeiro LA, Nappo SA. O papel da informação como medida preventiva ao uso de drogas entre jovens em situação de risco. Ciênc. saúde coletiva [Internet]. 2010[acesso em 2012 jul 7]; 15(3):699-708.

Disponível em: http://www.scielo.br/scielo.php?script=sci_arttext\&pid=S1413$81232010000300012 \& \operatorname{lng}=$ en\&nrm=iso.

Santos RMS. Prevenção de droga na escola. Uma abordagem psicodramática. Campinas:Papirus; 1997.

Sá-Silva JR, Almeida CD, Guindani JF. Pesquisa documental: pistas teóricas e metodológicas. Revista brasileira de história \& ciências sociais [Internet]. 2009 [acesso em 2012 dez 12]; I(I). Disponível em:

http://www.rbhcs.com/index_arquivos/Artigo.Pesquisa\%20documental.pdf.

Silva CR, Gobbi BC, Simão AA. O uso da análise de conteúdo como uma ferramenta para a pesquisa qualitativa: descrição e aplicação do método. Organ. rurais agroind. $2005 ; 7(1): 70-81$.

SilvaD. De onde vêm as palavras. Origens e curiosidades da língua portuguesa.São Paulo: A Girafa,2004.

Silva DAS, Pereira IM, Almeida MB, Silva RJS, Oliveira ACC. Estilo de vida de acadêmicos de educação física de uma universidade pública do estado de Sergipe, Brasil. Rev. Bras. Ciênc. Esporte [Internet]. 2012 [acesso em 2012 dez 12]; 34(1):53-67. Disponível em:http://dx.doi.org/10.1590/S010132892012000100005.

Silva LVER, Malbergier A, Stempliuk VA, Andrade AG. Fatores associados ao consumo de álcool e drogas entre estudantes universitários. Rev Saúde Pública. 2006;40(2):208-18.

Simão MO, Kerr-Corrêa F, Smaira SI, Trinca LA, Floripes TMF, Dalben I, Martins RA, Oliveira JB, Cavariani MB, Tucci AM. Prevention of "risky" drinking among students at a Brazilian university. Alcohol \& Alcoholism;43(4):470-6.

Souza FGM, Landim RM, Perdigão FB, Morais RM, Carneiro Filho BA. Consumo de drogas e desempenho acadêmico entre estudantes de medicina no Ceará. Rev Psiquiat Clín. 1999;26(4):188-94. 
Stempliuk VA, Barroso LP, Andrade AG, Nicastri S, Malbergier A. Comparative study of drug use among undergraduate students at the University of São Paulo - São Paulo campus in 1996 and 2001. Rev Bras Psiquiat. 2005;2(3):185-93.

Stocco JAP. (Re)pensando a construção dos projetos político pedagógicos de curso de graduação. Secretariado Executivo SEER [Internet]. 2005 [acesso em 2011 jun 25];1. Disponível em:www.upf.br/seer/index.php/ser/article/view/1737/1147.

Tamosauskas MRG. De médico especialista a professor de medicina: a construção dos saberes docentes[dissertação] [Internet]. São Bernardo do Campo:Universidade Metodista de São Paulo; 2003. [acesso em 2009 abr 22]. Disponível em: <http:// www.abemeducmed.org.br/pdf_tese/dissertacao_marcia_tamosauskas.pdf $>$.

Tavares BF, Béria JU, Lima MS. Prevalência do uso de drogas e desempenho escolar entre adolescentes. Rev. Saúde Pública. 2001; 35(2):150-8.

Tockus D, Gonçalves PS. Deteç̧ão do uso de drogas de abuso por estudantes de medicina de uma universidade privada. J. Bras. Psiquiatr. 2008; 57(3):1847.

Turato, ER. Tratado de metodologia da pesquisa clínico-qualitativa.Petropolis: Vozes; 2003.

Underwood B, Fox K, Manogue M. Tobacco, alcohol and drug use among dental undergraduates at one English university in 1998 and 2008. Br Dent J. 2010; 27.208(4):E8; discussion 164-5.

UNESCO. Declaração Mundial sobre a Educação Superior. Conferência Mundial sobre a Educação Superior no século XXI- Visão e Ação [Internet]. 1998 [acesso em 2011 nov 7]. Disponível em:http://www.unesco.org/education/educprog/wche/declaration_spa.htm.

UNODC United Nations Office for Drug Control and Crime. World Drug Report 2009 [Internet]. 2009 [acesso en 2011 Dec 20]. Disponível em: https://www.unodc.org/documents/wdr/WDR_2009/WDR2009_eng_web.pdf.

UNODC United Nations Office on Drugs and Crime. World Drug Report 2012 [Internet]. 2012 [acesso em 2013 Mar 3]. Disponível em: http://www.unodc.org/unodc/data-and-analysis/WDR-2012.html.

US Department of Education, Office of safe and Drug-Free Schools.Alcool and other drug prevention on college: model programs [Internet]. 2008 [acesso em 2011 Aug 5]. Disponível em:http://edupubs.ed.gov.

Vasconcellos CS. Planejamento: plano de ensino-aprendizagem e projeto educativo. São Paulo:Libertat; 1995.

Veiga, IPA, organizador.Projeto político-pedagógico da escola: uma construção possível. 23.ed. Campinas: Papirus, 2001. 
Veiga, IPA. Inovações e projeto político-pedagógico: uma relação regulatória ou emancipatória?Cad. CEDES. 2003 dez.;23(61):267-81.

Wagner GA, Andrade AG. Uso de álcool, tabaco e outras drogas entre estudantes universitários brasileiros. Rev Psiquiat Clin. 2008; 35:45-8.

Wagner GA, Oliveira LG, Barroso LP, Nishimura R, Ishihara LM, Stempliuk VA, Duarte PCAV, Andrade AG. Drug use in college students: a 13-year trend. Rev Saúde Pública [Internet]. 2012 [acesso em 2013 May 29];46(3):497-504. Disponível em http://www.revistas.usp.br/rsp/article/view/33132/35866.

Walters ST, Bennett ME, Noto JV. Drinking on campus. What do we know about reducing alcohol use among college students? J Subst Abuse Treat. 2000;19:223-8.

Webb E, Ashton C H, Kelly P, Kamali F. Alcohol and drug use in UK university students. Lancet. 1996;348:922-5.

Wechsler H, Lee JE, Kuo M, Seibring M, Nelson TF, Lee H. Trends in college binge drinking during a period of increased prevention efforts. Findings from 4 Harvard School of Public Health College Alcohol Study surveys: 1993-2001. J Am Coll Health.2002;51(1):37. 